CULTURA DE TECIDOS VISANDO O MELHORAMENTO DE BANANEIRA (Musa spp.) ATRAVES DE INDUÇÃO DE MUTAÇÕES

EDSON TOBIAS DOMINGUES

Engenheiro Agrônomo

Orientador: Prof. Dr. AUGUSTO TULMANN NETO

Dissertaçāo apresentada à Escola Superior de Agricultura muiz de Queiroz", da Universidade de são Paulo, para obtenção do título de Hestre em Agronomia, Área de Concentração: Genética e Melhoramento de Plantas. 
Ficha catalográfica preparada pela Seção de Livros da Divisão de Biblioteca e Documentação - PCAP/USP

Domingues, Edson Tobias

D67lc Cultura de tecidos visando o melhoramento de bananeira (Musa spp) através de indução de mutações. Piracicaba, 1992.

$199 p$.

Diss.(Mestre) - ESALQ

Bibliografia

1. Banana - Melhoramento 2. Cultura de tecido

3. Mutação induzida I.Escola Superior de Agricultura Luiz de Queiróz, Piracicaba

$\operatorname{CDD} 634.772$ 
CULTURA DE TECIDOS VISANDO O MELHORAMENTO DE

BANANEIRA (Musa spp.) ATRAVES DE INDUÇÃo DE MUTAÇÓES

Edson Tobias Domingues

Aprovada em: $15 / 12 / 92$

Comissão Julgadora:

Prof. Dr. Augusto Tulmann Neto CENA/USP

Prof. Dr. Paulo Roberto de Camargo e Castro ESALQ/USP

Dr. Marcos Antonio Machado IAC

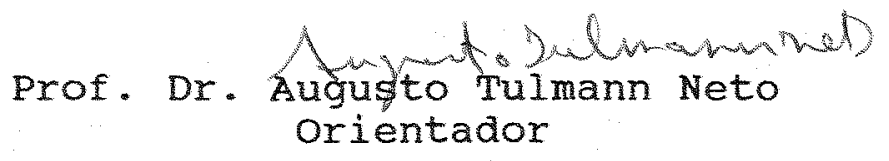


Aquele que nos deu a vida e o direito de partilhar de sua perfeita criação,

Agradeço.

Aos meus pais Lúcio e Nair,

ofereço. 


\section{AGRADECIMENTOS}

Ao Dr. Augusto Tulmann Neto, pela orientação, amizade e interesse por minha carreira cientifica.

A Dr Beatriz M. J. Mendez pela amizade e inestimável auxílio na elaboração deste trabalho.

Ao Prof. Dr. Akiniko Ando pela amizade e ensinamentos transmitidos.

À Professora Beatriz Appezzato e à Magali Aparecida Rodrigues Machado pela orientação nos estudos de cortes histológicos realizados.

Ao desenhista João Geraldo do CENA, pela ajuda na elaboração das ilustrações deste trabalho.

Aos técnicos Benedita Inês F.P. Rodrigues e wlamir de Aguiar Godoy, e a José Benedito Alves e Paulo Cassieri, pelo auxílio nos trabalhos em laboratório e casa de vegetação.

À CAPES e CNPq, pela concessão das bolsas de estudo.

Aos Departamentos de Genética e Botânica da Escola Superior de Agricultura "Luiz de Queiroz" - ESALQ/USP.

À Seçao de Radiogenética do Centro de Energia Nuclear na Agricultura, onde foi realizada esta pesquisa CENA/USP.

A todos que de forma direta ou indireta colaboraram para a realização deste trabalho, agradeço. 
fNDICE

Página

LISTA DE TABELAS

viii

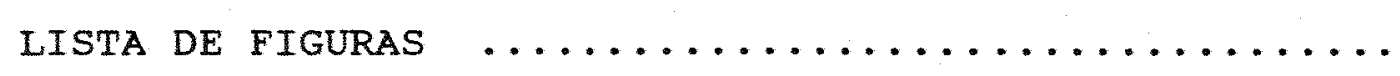

$\mathrm{x}$

LISTA DE ABREVIATURAS $\ldots \ldots \ldots \ldots \ldots \ldots \ldots \ldots$

xii

RESUMO

xiii

SUMMARY

xvii

1. INTRODUÇÃo

01

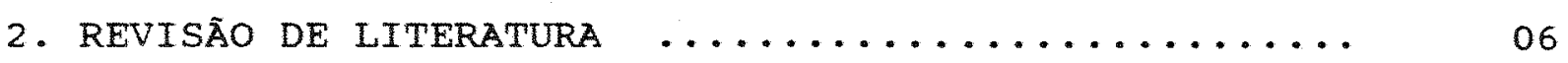

2.1. Importância da cultura $\ldots \ldots \ldots \ldots \ldots \ldots \ldots .06$

2.2. Aspectos históricos $\ldots \ldots \ldots \ldots \ldots \ldots \ldots \ldots \ldots$. 08

2.3. Aspectos botânicos $\ldots \ldots \ldots \ldots \ldots \ldots \ldots \ldots . . . \cdots$

2.4. Aspectos genéticos $\ldots \ldots \ldots \ldots \ldots \ldots \ldots \ldots \ldots$

2.5. Principais problemas da cultura $\ldots \ldots \ldots \ldots \ldots$

2.6. Aspectos do melhoramento da bananeira ....... 28

2.6.1. Melhoramento convencional ........ 29

2.6.2. Melhoramento não convencional $\ldots \ldots \ldots .34$

$2 \cdot 6 \cdot 2 \cdot 1$. Micropropagação in vitro .... 34

2.6.2.2. Embriogênese somática ...... 39

2.6.2.3. Cultivo de células e obtenção de Protoplastos .......... 41

2.6.2.4. Variação somaclonal ....... 44

2.6.2.5. Indução de mutação $\ldots \ldots \ldots \ldots .45$ 


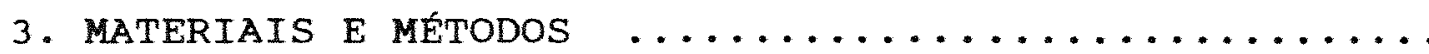

3.1. Obtenção e cultivo de meristemas iniciais de plantas do campo, obtidos a partir de ápices vegetativos ou florais ................. 56

3.1.1. Capacidade de brotação de ápices caulinares extraidos de diferentes maneiras ....

3.1.2. Comparação de meio líquido com e sem agitação com meio semi-sólido $\ldots \ldots \ldots \ldots \ldots$

3.1.3. Influência do BAP na brotação de ápices caulinares $\ldots \ldots \ldots \ldots \ldots \ldots \ldots \ldots \ldots$

3.1.4. Indução de enraizamento de plântulas ob tidas in vitro $\ldots \ldots \ldots \ldots \ldots \ldots \ldots \ldots$

3.2. Radiossensitividade de ápices caulinares de bananeira "Maçã" (grupo AAB) .............. 66

3.3. Isolamento dos setores mutados $\ldots \ldots \ldots \ldots \ldots . \ldots .68$

3.4. Aclimatação das plântulas em solo .......... 70

3.5. Isolamento do Fusarium f. sp. cubense ....... 71

3.6. Inoculação em casa de vegetação ........... 73

3.7. Avaliação da variabilidade fenotípica ....... 76

3.8. Indução da embriogênese somática $\ldots \ldots \ldots \ldots \ldots . . .77$

3.8.1. Obtenção das estruturas embriogênicas ... 78

3.8.2. Obtenção desenvolvimento e germinação

dos embrióides $\ldots \ldots \ldots \ldots \ldots \ldots \ldots \ldots$

3.9. Cultivo de células e obtenção de protoplastos 
4. RESULTADOS E DISCUSSÃo $\ldots \ldots \ldots \ldots \ldots \ldots \ldots \ldots \ldots$

4.1. Obtenção e cultivo de meristemas iniciais de plantas do campo, obtidos a partir de ápices vegetativos ou florais $\ldots \ldots \ldots \ldots \ldots \ldots \ldots \ldots$

4.1.1. Capacidade de brotação de ápices caulinares extraidos de diferentes maneiras ....

4.1.2. Comparação de meio liquido com e sem agitação com meio semi-sólido $\ldots \ldots \ldots \ldots \ldots$

4.1.3. Influência do BAP na brotação de ápices caulinares $\ldots \ldots \ldots \ldots \ldots \ldots \ldots \ldots$

4.1.4. Indução de enraizamento de plantulas ob tidas in vitro $\ldots \ldots \ldots \ldots \ldots \ldots \ldots \ldots$

4.2. Radiossensitividade de ápices caulinares de bananeira "Maçã" (grupo AAB) ................. 110

4.3. Isolamento dos setores mutados ............ 115

4.4. Aclimatação das plântulas em solo .......... 118

4.5. Isolamento do Fusarium f. sp. cubense ........ 120

4.6. Inoculação em casa de vegetação ............ 123

4.7. Avaliação dos variantes fenotípicos obtidos .... 129

4.8. Indução da embriogênese somática ........... 139

4.8.1. Obtenção das estruturas embriogênicas ... 139

4.8.2. Obtenção desenvolvimento e germinação dos embrióides ....................... 149

4.9. Cultivo de células e obtenção de protoplastos .. 154 4.10. Considerações finais e perspectivas futuras ... 160 
vii

Página

5. CONCLUSÕES

164

REFERENCIASS BIBLIOGRÁFICAS

169

APENDICES 


\section{LISTA DE TABELAS}

1. Número médio de brotos obtidos através de cinco tipos diferentes de ápices caulinares de bananeira "Maçã" (Grupo AAB) cultivados in vitro em meio líquido ......

2. Número médio de brotos obtidos através de ápices cauIinares de bananeira "Maçã" cultivados in vitro em meio semi-sólido e líquido com e sem agitação ........

3. Média de brotos obtidos por ápice caulinar de bananeira "Maçā" (Grupo AAB) cultivado in vitro sob diversas

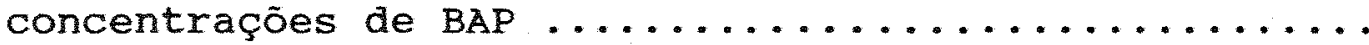

4. Peso e número médios de brotos obtidos por parcela (contendo dois ápices caulinares cada) para bananeira cultivar Maçà (Grupo AAB) cultivados in vitro sob diversas concentrações de BAP ..................

5. Comprimento médio de raizes (cm) em plantulas de bananeira "Maçã" (Grupo AAB) cultivadas in vitro, através do uso de diversas concentrações de auxinas .........

6. Número médio de raizes em plântulas de bananeira "Maçã" cultivadas in vitro, durante enraizamento através de diversas concentrações das auxinas IAA, IBA e NAA.

7. Crescimento médio (cm) de plântulas de bananeira "Maçã" (Grupo $A A B$ ) cultivadas in vitro, através do uso de diversas concentrações de auxinas .............

8. Número médio de brotos obtidos através do tempo de cultivo in vitro de ápices caulinares de bananeira "Maçã", após irradiação com raios gama ........... 
9. Ganho de peso médio em ápices caulinares de bananeira Maçã cultivados in vitro, tratados com radiação gama.

10. Número médio de esporos produzidos através do tempo pelo Fusarium oxysporum f.sp. cubense cultivado em BDA

11. Inoculação de plantas jovens de bananeira "Maçã" (grupo AAB) com Fusarium oxysporum f. sp. cubense, obtidas após irradiação e micropropagação de ápices caulinares

12. Variações fenotípicas e respectivas frequências em bananeira "Maçã" (grupo AAB) micropropagada a partir de ápices caulinares irradiados e subcultivados por qua -

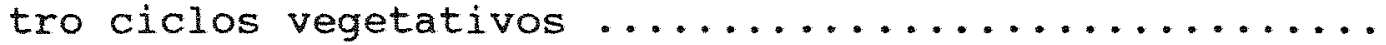

13. Percentual médio de estruturas embriogênicas induzidas em diversos clones de bananeira com a utilização de diversas concentrações do regulador de crescimento Dicamba

14. Percentual médio de oxidação dos explantes de diversos clones de bananeira com a utilização de Dicamba .....

15. Posição média dos explantes que apresentaram melhor resposta as diversas concentraçōes de Dicamba .......

16. Percentual médio de formação de calos e pró-embrióides à concentração de $6.63 \mathrm{mg}$ de Dicamba, com $2 \%$ e $4 \%$ de

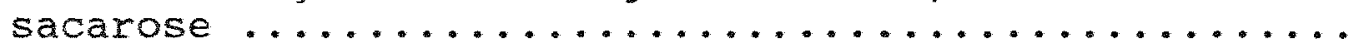

17. Percentual médio de embrióides verdes, oxidados e que formaram raiz em meio de germinação com zeatina ...... 


\section{LISTA DE FIGURAS}

FIGURA No

Página

1. Desenho ilustrativo de uma planta enraizada in vitro, da qual é possivel o re-isolamento de ápices caulinares. Os números indicam 5 tipos diferentes de explan-

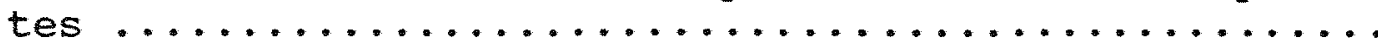

2. Desenho ilustrativo do processo de irradiação (M) de ápices caulinares (1) e sua micropropagação (2) por diversas gerações vegetativas, obtendo plântulas $M_{0} V_{4} e$ $\mathrm{M}_{2} \mathrm{~V}_{4}(3)$ as quais são inoculadas em casa de vegetação (4) com suspensão de esporos do Fusarium oxysporum $f$.

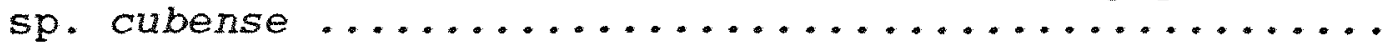

3. Desenho ilustrativo do processo de indução da embriogênese somática em Musa. A partir de uma plântula obtida in vitro (a) é extraido segmento contendo rizoma e pseudocaule (b), o qual é seccionado transversalmente em segmentos (c) de aproximadamente $2 \mathrm{~mm}$ de diametro (numerados de 1 a 9) plaqueados em meio com Dicamba (d)

4. Esquema utilizado para os trabalhos de seleção de plantas de bananeira cultivar Maça (grupo AAB) resistentes ao Fusarium oxysporum f.sp. cubense ..............

5. Foto ilustrativa de plantas de bananeira cultivar Maçã (grupo $A A B$ ) com sintomas iniciais (à direita) e com sintomas mais avançados (à esquerda) da infestação com Fusarium oxysporum f.sp. cubense, causador da Fusariose da bananeira

6. Foto ilustrativa de plantas de bananeira cultivar Maçã (grupo $A A B$ ) com internódios curtos (planta anã), à esquerda, obtida a partir da irradiação com 40 Gy de raios gama, e planta obtida do controle, com internódios longos (à direita) $\ldots \ldots \ldots \ldots \ldots \ldots \ldots \ldots \ldots \ldots \ldots . . . \ldots \ldots$ 
7. Foto ilustrativa de plantas de bananeira cultivar Maçã (grupo $A A B$ ) na geração $M_{2} V_{4}$, apresentando folhas variegadas para as cores verde e branca, obtida através da irradiação de ápices caulinares com raios gama na dose

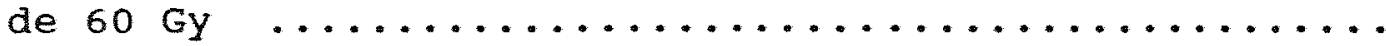

8. Foto ilustrativa de estruturas globulares induzidas em tecidos do rizoma e pseudocaule de bananeira através do uso do regulador de crescimento Dicamba (16x) ....

9. Foto ilustrativa de calos translúcidos (a), opacos (b) e estruturas globulares (c) induzidos em tecidos do rizona e pseudocaule de bananeira através do uso do regulador de crescimento Dicamba $(12 x) \ldots \ldots \ldots \ldots$

10. Foto ilustrativa de embriões somáticos de bananeira em fase de desenvolvimento $(12 x) \quad \ldots \ldots \ldots \ldots \ldots \ldots \ldots$

11. Foto ilustrativa de embrióes somáticos de bananeira apresentando germinação imperfeita, com ausência de e -

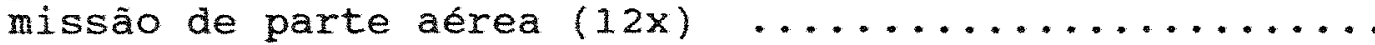

12. Foto ilustrativa de suspensão celular com células desuniformes. Células túrgidas (a), células túrgidas oxidadas (b) e células adequadas para o cultivo (c) (200x)

13. Foto ilustrativa de suspensão celular com células uniformes, adequadas para o cultivo $(200 x) \ldots \ldots \ldots . .$.

14. Foto ilustrativa do isolamento de protoplastos de bananeira a partir de suspensão celular $(200 x)$........

15. Desenho ilustrativo da sequência dos trabalhos realiza-

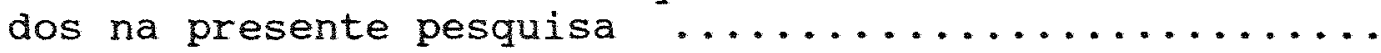




\section{LISTA DE ABREVIATURAS}

No decorrer do presente trabaino foram usadas abreviaturas, cujo significado é dado a seguir:

BAP - 6-benzil-aminopurina

$\mathrm{BDA}$ - Meio de cultura constituido de batata-ágar-dextrose

$B O D$ - estufa incubadora com temperatura controlada

CPW - solução de nutrientes descrita por FREARSON et al. (1973)

DICAMBA - ácido 3,6 dicloro - 2 - metoxibenzbico

2,4-D - ácido 2,4-diclorofenoxiacético

$\mathrm{GR}_{50}$ - Dose ou concentração de mutagênico responsável pela redução de $50 \%$ no crescimento dos explantes tratados.

IBA - ácido indolbutirico

IAA - acido 3-indolacético

$L D_{50}$ - Dose ou concentração de mutagênico responsável pela letalidade de $50 \%$ dos explantes tratados.

MS - meio de cultura descrito por MURASHIGE \& SKOOG (1962)

MW - vitaminas descritas por MOREL \& WETMORE (1951)

$\mathrm{M}_{\mathrm{M}} \mathrm{V}_{\mathrm{N}}$ - Plantas de propagação vegetativa, cultivadas in vitro e que sofreram tratamentos mutagênicos e foram subcultivadas vezes

NAA - ácido Naftalenacético

rpm - rotações por minuto.

SH - Meio de cultura descrito por SCHENK \& HILDEBRANDT (1972)

$W / m^{2}$ - intensidade Iuminosa 


\title{
CULTURA DE TECIDOS VISANDO O MELLHORAMENTO DE BANANEIRA (Musa spp.) ATRAVÉS DE INDUÇão DE MUTAÇões
}

\author{
Autor: Edson Tobias Domingues \\ Orientador: Prof. Dr. Augusto Tulmann Neto
}

\section{RESUTMO}

Os métodos tradicionais de melhoramento de plantas apresentam certas dificuldades para algumas culturas, principalmente as de propagação vegetativa, como é o caso das bananeiras e plátanos. Os cultivares são normalmente constituídos de híbridos interespecificos, sendo comum a heterozigozidade a poliploidia e a esterilidade na maioria dos clones, sendo que esta última cria frequentemente, uma barreira insuperável para os cruzamentos.

Devido à propagação vegetativa, estas culturas possuem uma homogeneidade genética muito grande nas plantações, tornando-a vulnerável a uma série de doenças, dentre as quais destaca-se a Fusariose, causada pelo Fusarium oxysporum f.sp. cubense, a qual impossibitita o plantio comercial de diversos cultivares, como é o caso da bananeira cultivar Maçã (grupo AAB), de ampla aceitação por todo o Brasil. 
Uma vez que existe um grande potencial para a biotecnologia nesta cultura, o presente trabalho buscou adaptar diferentes metodologias de cultura de tecidos visando trabalhos de indução de mutações em Musa.

Foram extraidos meristemas de bananeira dos cultivares Maçã, Nanica, Nanicão e Grand Naine (clone GN-60), os quais foram inoculados em meio modificado de MURASHIGE \& SKOOG (1962). Após multiplicação in vitro as plantas obtidas foram utilizadas para a realização de diversos experimentos.

Foram testados cinco diferentes tipos de extração de ápices caulinares, a serem utilizados a partir de plantas in vitro para reinicio da micropropagação sendo constatado que os ápices caulinares dos quais foram retiradas as bainhas foliares e aqueles dos quais foi eliminada a dominância apical tenderam a apresentar maior número de brotações.

Comparou-se os diferentes niveis de brotação obtidos em meio de cultura semi-sólido com os obtidos em meio líquido com e sem agitação, concluindo-se que o liquido sob agitação tendeu a estimular uma maior brotação que o semi-sólido, e ambos superaram o meio líquido sem agitação.

Foi ainda avaliada a menor concentração de BAP indutora da maior taxa de brotação in vitro, para o cultivar Maçã, entre as concentrações de $0 ; 2,5 ; 5,0 ; 7,5 ; 10,0 ; 12,5$; 15,$0 ; 17,5$ e $20,0 \mathrm{mg} / 1$. A menor concentração que permitiu a obtenção de um maior número de brotos situou-se ao redor de 5,0 $\mathrm{mg} / 1$ de BAP. 
Para um enraizamento mais eficiente em plântulas de bananeira comparou-se os reguladores de crescimento IAA, IBA E NAA em diferentes concentrações. Observou-se que na concentração mais baixa de NAA e IBA $(0,1 \mathrm{mg} / 1)$ o enraizamento foi mais adequado.

Estudou-se a radiossensitividade de ápices caulinares do cultivar Maçã às doses de $0,20,40,60,80$, e 100 Gy. Observou-se que a dose de 20 Gy provocou um leve estímulo a multiplicação clonal do cultivar, enquanto que a que causou $50 \%$ de letalidade $\left(L D_{50}\right)$, esteve por volta de $40 \mathrm{~Gy}$, já as doses de 80 e 100 Gy não permitiram a recuperação de brotações.

os explantes irradiados foram subcultivados por 4 ciclos vegetativos $\left(M_{1} V_{4}\right)$, este número de gerações foi considerado satisfatório para o isolamento de setores mutados, uma vez que nesta geração, in vitro, foram observadas algumas alterações fenotipicas para variegação foliar, a partir de explantes irradiados nas doses de 40 e $60 \mathrm{~Gy}$.

As alterações fenotípicas, no entanto, tornaram-se mais perceptiveis em casa de vegetação, onde a partir de 2070 plantas observadas quantificou-se as alterações mais significativas. Foram obtidas plantas com folhas variegadas, plantas com maior teor de antocianina e plantas com alterações para o formato e arquitetura foliar e de planta.

Após o isolamento do Fusarium oxysporum f. sp. cubense a partir de plantas de campo infestadas, foi realizado o seu cultivo em meio BDA, obtendo-se após 15 dias uma maior produção 
$x v i$

de esporos, a partir dos quais foram confeccionadas suspensões para inoculação em casa de vegetação.

Realizou-se a inoculação de 2765 plantas, de bananeira "Maçã", originadas de ápices caulinares irradiados e micropropagados in vitro por 4 gerações vegetativas. A inoculação foi realizada através de $50 \mathrm{ml}$ de suspensão contendo $5 \times 10^{4}$ esporos/ml do Fusarium. Embora as respostas tenham sido diferenciadas de planta à planta, não foram observadas plantas resistentes ao fungo. o sistema utilizado permitiu uma triagen rápida e eficiente das plantas susceptiveis.

Seguindo metodologia descrita por Novak et al. (1989), induziu-se a formação de estruturas embriogênicas sobre tecidos do rizoma e pseudocaule de plantas pertencentes aos cultivares Maçã, Grand Naine (clone GN-60) e Nanicão. Para esta finalidade utilizou-se o regulador de crescimento Dicamba, cuja melhor concentração, variou em função do cultivar testado. Destas estruturas obtidas não se originaram plantas diretamente, mas o seu subcultivo em meio liquido, permitiu o surgimento de novas estruturas que parecem possuir boa capacitação embriogênica, uma vez que apresentaram emissão de radiculas e início de emissão de parte aérea. Não foi possivel a recuperação de plantas por embriogênese somática até o momento.

A partir do subcultivo das estruturas embriogênicas previamente descritas foram obtidas suspensões celulares, as quais mostraram-se apropriadas para o isolamento de protoplastos. 
xvii

\title{
TISSUE CULTURE AIMING AT MUTATION BREEDING \\ IN BANANA (Musa spp.)
}

\author{
Author: Edson Tobias Domingues \\ Adviser: Prof. Dr. Augusto Tulmann Neto
}

\section{SUMTMARY}

Conventional plant breeding methods have shown difficulties for some crops, principally for the vegetative propagated ones such as bananas and plantains. The cultivars normally consist of interspecific hybrids and heterozygosity and polyploidy are commonly seen in most of the clones. Its assexual behaviour is often a serious limitation to cross-breeding.

Due to the vegetative propagation, those cultivars show high genetic homogeneity and this makes them vulnerable to serious diseases such as Fusarium wilt caused by Fusarium oxysporum f.sp. Cubense which hampers commercial production in the cultivars with the $A A B$ genome, as "Maçã", of large acceptance in Brazil.

As there exists a great potential of biotecnology to this crop, the present work was carried out to adapt different tissue culture methodologies to Musa species, aiming at future mutation breeding programs. Meristems were extracted from the cultivars Maçã, Nanica, Nanicão and Grand Nain (clone GN-60), and were inoculated on the modified MURASHIGE \& SKOOG (1962) medium. 
xviii

After in vitro propagation, these plants were used for several experiments.

Shoot tip apices were extracted in five diferent ways. After in vitro propagation it was found that those without sheath and apical dominance tended to produce a larger number of buds.

Different levels of bud formation were observed on semi-solid medium culture when compared with agitated or static liquid ones. The agitated liquid medium tended to increase the number of buds more than the semi-solid one which was better than static liquid one.

The growth regulator $B A P$ was used in several concentrations $(0,2.5,5.0,7.5,10.0,12.5,15.0,17.5$ and $20.0 \mathrm{mg} / 1$ ) for bud formation of the shoot tip apices. The lowest concentration which permitted a higher number of cluster formation was around $5.0 \mathrm{mg} / 1$ for "Maçã .

For efficient rooting of in vitro plants, the auxins IAA, IBA and NAA with different concentrations were tested. Lower concentrations of NAA or IBA $(0.1 \mathrm{mg} / 1)$ or IAA $(0.5 \mathrm{mg} / 1)$ showed high efficiency, permitting rooted plants formation in two weeks. shoot tip apices radiosensitivity was carried out in "Maçã". Doses of $0,20,40,60,80$ e 100 Gy were used. Twenty Gy showed low stimulus of bud formation when compared with the control. Fourty Gy was found to be the dose that permitted the survival of 50 \% of plants $\left(L_{50}\right)$. Higher doses as 80 and 100 Gy did not permit bua formation. 
Irradiated explants were subcultivated for four vegetative generations $\left(M_{2} V_{4}\right)$. This procedure was found to be sufficient for isolation of the mutated sectors, because it was possible to observe in this generation some phenotypic changes of leaf variegation at the doses of 40 and $60 \mathrm{~Gy}$.

Phenotypic changes, meanwhile, were more perceptible in green house condition where they were quantified in 2070 plants. Plants with leaf variegation, concentrated anthocyanin, disturbed leaf shape and changed plant and leaf architecture were observed. After isolation of Fusarium oxysporum f. sp. cubense from infested plants in the field, its cultivation was carried out in BDA medium. After 15 days, higher production of spores was obtained and they were used to prepare suspention for inoculation in green house.

The inoculation was carried out to 2765 plants of "Maçã", originated from irradiated shoot tip apices that were micropropagated in vitro for 4 vegetative generations. The inoculation was made. Fifty $\mathrm{ml}$ of suspention containning $5 \times 10^{4}$ spores/ml of Fusarium was inoculated to each plant. Although the differentiated responses, no resistant plant was found. The utilized system permitted a quick and efficient screening of the susceptible ones.

Following the methodology described by NOVAK et al. (1989), embryogenic structure formation was induced on corm and pseudostem tissues of the cultivars Maçã, Grand Nain (clone GN-60) and Nanicão. Dicamba, a growth regulator, was used for this 
objective. The best concentration was changed in the function of tested cultivar. These structures did not originate plants directly, but after liquid subcultivation, permitted the appearance of new structures which seems to have a good embryogenic capacity. They permitted root emission and initiation stem formation, but it was not possible to regenerate plants by somatic embryogenesis until the present.

From liquid subculture of embryogenic structure, cell suspension was obtained and this showed to be appropriate for protoplast isolation. 


\section{INTRODUÇÃO}

A bananeira é uma das principais frutiferas mundiais, constituindo-se em um dos componentes básicos na alimentação de milhões de pessoas. A produção é inteiramente dependente de clones não melhorados que foram selecionados na natureza, domesticados e mantidos em cultivo. As mutações espontâneas têm contribuído para a ampliação da limitada diversidade genética em Musa (NOVAK, 1991).

A poliploidia e a esterilidade são fatores que dificultam seriamente o melhoramento dos cultivares de Musa (SHEPHERD, 1983). Os métodos tradicionais de melhoramento de plantas apresentam certas dificuldades para algumas culturas, principalmente as de propagação vegetativa, como as bananeiras e os plátanos (ROWE, 1984).

o sistema genético do gênero Musa é extremamente complexo. Os cultivares são normalmente constituidos de hibridos interespecificos, sendo comum a esterilidade, heterozigozidade e a poliploidia na maioria dos clones. o comportamento assexual tornase, frequentemente, uma barreira insuperável para uso de cruzamentos, havendo irregularidades meióticas e a formação de gametas poliplóides, causando situações cromossômicas incomuns e recombinações desiguais nos hibridos. Os programas convencionais de melhoramento tornam-se de dificil execução em face da complexidade 
genética apresentada, sendo que existe um grande potencial para a biotecnologia nesta cultura (PERSLEY \& DE LANGHE, 1987).

A cultura da bananeira, devido a propagação vegetativa, possui uma homogeneidade genética muito grande nas plantações, tornando-a vulnerável a uma série de problemas que afligem a cultura, dentre as quais destacam-se as doenças. Algumas variedades de interesse comercial chegam a ter produção nômade para escapar da presença do patógeno, é o caso das bananas do grupo AAB, ao qual pertence o cultivar Maçã, entre outros.

HWANG \& KO (1987), buscaram ampliar a variabilidade através do cultivo de ápices caulinares gerando variação somaclonal a qual utilizaram em programa de melhoramento para resistência a doenças.

As culturas de propagação vegetativa, dentre elas as bananeiras e os plátanos, são usualmente heterozigotas e um tratamento mutagênico pode recuperar alelos recessivos por mutação ou deleção de alelos dominantes. A indução de mutação visa a alteração de uma ou poucas caracteristicas de cultivares bem estabelecidos, mas sem alterar as características desejáveis dos mesmos (BROERTJES \& VAN HARTEN, 1978, 1988). A indução de mutação pode ser particularmente importante para espécies estéreis de Musa onde não existe reprodução sexual para recombinação da variabilidade genética (KRIKORIAN \& CRONAUER, 1984).

Vários autores têm utilizado tratamentos mutagênicos para o melhoramento da bananeira. DE GUZMAN et al. (1976) indicaram a irradiação de explantes, constituidos de parte do rizoma e pseu- 
docaule da planta, anteriormente à extração de ápices caulinares para cultivo in vitro, o que resultou em um número relativamente baixo de material mutado. TULMANN NETO et al. (1989), irradiaram rizomas de plantas adultas in vivo, induzindo brotações laterais para seleção ao Mal-do-Panamá. NOVAK et al. (1986), descreveram a resposta de ápices meristemáticos à irradiação gama. NovAK et al. (1990), utilizaram radiação gama para indução de mutação em ápices meristemáticos cultivados in vitro de diversos clones de bananas de sobremesa e plátanos, enquanto que OMAR et al. (1989), utilizaram mutagênico químico (Metanossulfonato de Etila).

Por outro lado a embriogênese somática em importantes cultivares econômicos oferece novas oportunidades para a obtenção de novos cultivares. A suspensão embriogênica representa uma fonte para a criação de variabilidade genética através da variação somaclonal provavelmente envolvida no processo. o sistema unicelular também facilita a indução e seleção de mutantes com resistência a doenças ou tolerância ao estresse ambiental (NovAK, 1991).

A principal finalidade deste trabalho refere-se à utilização de cultura de tecidos e de indução de mutaçóes visando a ampliação da variabilidade genética em Musa spp. Para tanto realizou-se uma série de experimentos. Com a finalidade de se conhecer melhor os fatores que estimulam uma maior brotação em ápices caulinares de bananeira cultivados in vitro comparou-se, num primeiro experimento, ápices caulinares de bananeira extraídos 
através de cinco diferentes maneiras, a seguir o meio liquido com e sem agitação com o semi-sólido e as concentrações de BAP mais adequadas para o cultivar Maçã.

A seguir foi realizado experimento para a comparação dos reguladores de crescimento IAA, IBA $e$ NAA em diferentes concentrações para o enraizamento de plântulas de bananeira in vitro.

Com a finalidade de se iniciar programa de melhoramento em bananeira "Maçã" através de indução de mutações realizou-se ensaio de radiossensitividade de ápices caulinares para determinação do $\mathrm{LD}_{50}$ e do $\mathrm{GR}_{50}$. Após irradiação nas doses de 0, 20, $40,60,80$ e 100 Gy, os ápices sobreviventes foram micropropagados por quatro gerações vegetativas para o isolamento dos possiveis setores mutados. As plântulas originadas foram enraizadas e transferidas para solo em casa de vegetação para posterior inoculação com o Fusarium oxysporum f.sp. cubense para seleção à Fusariose.

As plantas originadas após irradiação dos ápices caulinares os quais foram subcultivados por quatro geraçōes vegetativas sofreram alteraçōes fenotipicas devido à variação somaclonal (em plantas originadas do controle) e à indução de mutação (em plantas originadas de ápices caulinares irradiados). As frequências destes variantes foram então quantificadas.

Com a finalidade de induzir estruturas embriogênicas em bananeira foi utilizado o regulador de crescimento Dicamba, em diversas concentrações para os cultivares Maçã e Nanicão e o clone 
GN-60. Este experimento teve como finalidade a determinação da concentração mais adequada para cada genótipo, os níveis de oxidação dos explantes e a posição da planta da qual foram obtidos os explantes mais responsivos aos tratamentos. Paralelamente buscou-se avaliar a formação de estruturas embriogênicas nos explantes tratados com Dicamba $(6,63 \mathrm{mg} / 1)$ sob diferentes niveis de sacarose $(2$ e $4 \%$ ).

Estas estruturas embriogênicas obtidas foram cultivadas em meio líquido sob elevada rotação com a finalidade de obtenção de suspensões celulares, a partir das quais foram obtidos embriões somáticos os quais após desenvolvimento foram postos em meio contendo dupla fase (uma sólida e outra líquida contendo zeatina) objetivando a germinação dos mesmos.

A partir de suspensões celulares obtidas das estruturas embriogênicas foram separadas aliquotas objetivando o isolamento de protoplastos através de soluçōes de enzima. 


\section{REVISÃo DE LITERATURA}

\subsection{Importância da cultura}

As bananas e os plátanos são culturas de vital importância para milhões de pessoas no mundo todo, seja como fonte de alimentação direta ou como fonte de divisas. A produção mundial alcança aproximadamente 71 milhões de toneladas por ano. Dois terços da colheita consistem em bananas de sobremesa (aproximadamente 46 milhões de toneladas), enquanto os plátanos ricos em amido e demais bananas de cozinhar representam um terço do total (aproximadamente 25 milhões de toneladas) (FAO, 1991).

A banana tem se destacado como um dos principais produtos de exportação de alguns paises da América central e do Sul. O Brasil é o segundo maior produtor mundial de banana (APENDICE 1), porém apenas $1.82 \%$ do que produz é exportado, isto se deve a diversos fatores dentre os quais destacam-se a distância deste país em relação aos países consumidores, a qualidade do produto (tipo de fruto, condições de transporte, embalagem, etc.) e a falta de maior empenho visando conquistar o mercado internacional. Outro fator bastante citado é o consumo interno da fruta, que é bastante satisfatorio desestimulando maior empenho dos produtores para a exportação (FRUTAS, 1988). 
o valor calorífico desta fruta é bastante elevado, fornecendo uma caloria por grama, além disto ela acaba se constituindo em uma importante fonte nutricional para alimentação humana devido ao seu valor energético, seu conteúdo mineral e vitamínico. Segundo SIMÃO (1971) e MOREIRA (1987) as bananas são ricas em carboidratos (aproximadamente 25\%), proteínas $(1,10)$, fibras, possui teores consideráveis em fósforo, $\mathrm{Ca}, \mathrm{Fe}, \mathrm{Cu}, \mathrm{Zn}, \mathrm{I}, \mathrm{Mn}$ e $\mathrm{Co}$, além de vitamina $A$, tiamina, riboflavina, niacina e vitamina $C$.

A banana pode ser consumida in natura ou utilizada na indústria para obtenção de farinhas de banana verde, farinha ou pó de banana madura, cremes, passa, purê, néctar, bananada, balas, geleia, vinho e vinagre (STOVER \& SIMMONDS, 1987).

A principal área de produção no Brasil é a região litorânea, responsável pela exportação e abastecimento dos grandes centros consumidores do país. o comércio brasileiro com o exterior é feito através do Estado de São Paulo, e é dirigido à Argentina e uruguai principalmente. Isto se deve a uma antiga politica internacional para o produto que determinava que os países produtores deveriam comercializar a banana com seus países vizinhos devido a grande perecibilidade da fruta. Hoje com a maturação e transporte dentro de câmaras frigorificas, este fruto pode, agora, ser destinado a mercados bem mais distantes (BUSCAR, 1985). 


\subsection{Aspectos historicos}

o gênero Musa, ao qual pertencem as bananeiras, foi criado por Lineu, o nome Musa provém do árabe (Mouz ou maouz) ou foi utilizado em homenagem a Antonius Musa, médico de otávio Augusto, o primeiro Imperador de Roma (64- 14 A.C.) (MEDINA, 1978). Já a palavra banana é originária das línguas serra-leonesa e liberiana (costa ocidental da África), por simples incorporação do termo cunhado pelos portugueses (MOREIRA, 1987).

As bananeiras existem no Brasil anteriormente ao seu descobrimento. Segundo MOREIRA (1987), quando Cabral aportou, encontrou os indigenas comendo bananas in natura de um cultivar muito digestivo que se supõe tratar-se do prata e um outro, rico em amido, que precisava ser cozido antes do consumo, chamado de "pacoba" que deve ser o cultivar Pacova.

Não se pode indicar com exatidão a origem da bananeira, pois ela se perde na mitologia grega e indiana. Atualmente, admite-se que seja originária do oriente, sul da china ou Indochina. Há referências da sua presença na Índia, Malásia e Filipinas, onde tem sido cultivada há mais de 4.000 anos. A historia registra a antiguidade da cultura. As sementes das bananeiras primitivas teriam $2 \mathrm{~cm}$, atualmente elas são geralmente estéreis e se apresentam como pequenos pontos escuros localizados no eixo central da fruta (MOREIRA, 1987). 


\subsection{Aspectos botânicos}

A bananeira é uma planta herbácea, de raizes fibrosas, com caule verdadeiro subterrâneo, denominado rizoma. o rizoma constitui o órgão de reserva da planta e possui várias gemas que dão origem a novos rebentos e internamente é composto de duas partes: cilindro central e córtex (SIMÃo, 1971). o ponto de união entre essas duas regiões é bem determinado pela concentração de feixes vasculares orientados no sentido longitudinal. As raízes, que surgem em grupos de quatro do ponto de intersecção entre o cilindro central e a casca, apresentam comprimento variável estendendo-se até 5,0 metros no sentido horizontal e 2,0 metros na direção vertical. Entretanto $70 \%$ delas se encontram a $20 \mathrm{~cm}$ de profundidade.

Embora a bananeira possua um grande porte, o ponto de crescimento vegetativo é relativamente pequeno, suas dimensões não diferem muito em relação aos meristemas de outras herbáceas (BARKER \& STEWARD, 1962).

Como em outras angiospermas, o ápice caulinar da bananeira toma a forma de uma cúpula central de células meristemáticas e órgãos laterais. o primórdio foliar origina-se como uma protuberância, subsequentemente este primórdio torna-se mais largo pela combinação do crescimento periférico em torno do ápice, uma expansão radial (BARKER \& STEWARD, 1962).

As gemas vegetativas da maioria das monocotiledôneas são laterais e ocorrem na axila da estrutura foliar. Entretanto 
Tomlinson', citado por FISHER (1978), notou que diversas monocotiledôneas possuem gemas vegetativas laterais as quais são opostas às folhas, isto é, estão a $180^{\circ}$ da posição axilar típica. Uma gema vegetativa isolada a qual está posicionada $180^{\circ}$ da axila da folna é a característica genérica de Musa (Musaceae). Tais gemas opostas às folhas ocorrem em todas as 10 espécies e cinco cultivares examinados, representando todas as quatro seções do gênero e todos os grupos de bananeiras e plátanos cultivados.

Skutch $^{2}$, citado por FISHER (1978) foi o primeiro a indicar esta caracteristica não usual em brotações laterais em bananeira, sugerindo um possivel sistema simpodial de crescimento, sistema este negado por BARKER \& STEWARD (1962). Eles argumentaram que o meristema verdadeiro é de origem adventicea, porque emerge de uma região de células vacuoladas não mostrando "tendência meristemática especifica". Entretanto, células do internódio e base foliar neste estágio são ainda inaturas e meristemáticas, embora elas não formen uma região de crescimento da atividade mitótica localizada. Ela não pode portanto ser considerada de origem adventícia. Todos os exemplos de gemas adventicias no rizoma são resultados de injúria e estão distribuidas ao acaso sem qualquer relação direta com a posição foliar no rizoma (FISHER, 1978).

1 TOMLINSON, P.B. Phylogeny of the scitamineae - morphological and anatomical considerations. Evolution, Lancaster 16: $192-213,1962$.

2 SKUTCH, A.F. Anatomy of leaf of banana, Musa sapientum L. var. Hort. Gros Michel. Botanical Gazette, chicago, 84: $337-91,1927$. 
HAMILTON (1965) e TULMANN et al. (1989) obtiveram a formação de gemas adventicias através de segamento da gema vegetativa principal de rizomas, tal processo induziu a formação de tecidos não diferenciados (calos), que permitiram o surgimento das gemas adventicias. Os autores comentam que tanto brotos de origem axilar, quanto de origem adventicia foram observados, e que a distinção de ambas é relativamente fácil, as primeiras são mais bulbosas na base, e obedecem uma posição determinada em relação à base foliar, enquanto que as últimas são mais afiladas e ocorrem em posições aleatórias.

Com relação ao número de cromossomos das brotaçōes originadas de gemas adventicias não houve diferenças observáveis tanto em cultivares diplóides quanto em triplóides (HAMILTON, 1965).

As gemas adventicias, uma vez que são formadas por uma ou poucas células são interessantes para trabalhos de indução mutação, uma vez que aumentam a possibilidade de recuperação de mutantes solidos.

A partir do meristema terminal são produzidas folhas que saem em posição helicoidal. As bainhas das folhas que são embricadas, unem-se e formam a parte aérea denominada pseudocaule. As folhas emergem do cilindro central em forma de vela. o crescimento da folha é rápido, de 2 a $7 \mathrm{~cm}$ diário, podendo atingir até 20 cm. São encontrados estômatos nas duas faces, em número de 3 a 5 vezes superior na superficie basal e apical do que na central. A duração da folha varia de 70 a 280 dias e durante a vida da 
bananeira, podem surgir de 30 a 50 folnas. Em condições favoráveis climaticamente, ocorre a emissão de uma folha a cada 7 dias e em condições desfavoráveis de baixa temperatura, de 15 a 21 dias. Esse comportamento interfere na duração do ciclo, no tamanho do cacho e na qualidade do fruto (SIMÃo, 1971).

A inflorescência tem início no pseudocaule após a formação da décima primeira folha, aproximadamente, ela surge do cilindro central e leva 30 dias, ou pouco mais, para emergir. A condição climática ideal é uma temperatura média de $25^{\circ} \mathrm{C} e$ precipitação de 150 - $180 \mathrm{~mm}$ mensais. A maior ou menor rapidez de emergência da inflorescência está na dependência das condiçōes climaticas reinantes. Em periodo quente e úmido o ciclo da inflorescência até o desenvolvimento do fruto se completa em 90 dias e, em condições de seca e de baixa temperatura ultrapassa 180 dias. A inflorescência da bananeira apresenta flores masculinas e femininas, podendo também ocorrer flores hermafroditas. As flores femininas encontram-se na base da ráquis e as masculinas na parte terminal. Quando surgem flores hermafroditas, estas se situam no ponto intermediário entre as femininas e as masculinas. As flores encontram-se dentro de um "coração" inicialmente volumoso que, após formar 10 a 12 verticilios ou pencas, apresenta a seguir, apenas flores masculinas. Cada bráctea que abre expõe um verticilio floral, o coração se reduz e mantém-se preso ao cacho até a maturação (SIMÃo, 1971).

Segundo MOREIRA (1987), a duração do ciclo varia de 10 a 18 meses em condições ideais de cultivo, sendo que de 10 a 12 
meses para a primeira produção e até 18 meses para bananais mais velhos.

Para a frutificação de bananas produzidas comercialmente, não há necessidade de polinização, pois os frutos se formam partenocarpicamente, enquanto que nas espécies selvagens ocorre a necessidade de polinização. A ausência de sementes em bananas comestiveis parece estar ligada ao arranjamento estrutural dos cromossomos, à poliploidia e à esterilidade dos órgãos de reprodução masculinos e femininos. Os frutos são colnidos entre 80 a 100 dias a partir da emergência da inflorescência, isto é, antes de atingir o seu completo desenvolvimento que deve levar de 120 a 150 dias (Simão, 1971).

São diversos os cultivares conhecidos no Brasil como mostra o APENDICE 2. O cultivar Maçã é um híbrido triplóide (grupo $A A B)$ com dominância de acuminata, bananeira de fruto delicado, disseminada por quase todo o país. Pseudocaule de 3,5 a 4 m de altura, verde-amarelado brilhante, com poucas e diminutas manchas de cor escura. Folhas revestidas de cerosidade na página inferior. Inflorescência semipêndula, de engaço verde. Frutos curtamente pedunculados, roliços, de casca fina e delicada, amarela, endocarpo de cor branca, macio, delicado, doce, perfumado, de sabor semelhante ao da maçã. Cachos relativamente pequenos, pesando em média 15 quilos, com 5 a 10 verticilos e 60 a 150 bananas. A banana mede de 10 a $16 \mathrm{~cm}$ de comprimento e pesa de 100 a 200 gramas.

Ela é resistente à sigatoka amarela e muito susceptivel à fusariose. Seu plantio tem declinado em função da sua 
alta susceptibilidade a essa moléstia. Para o consumo in natura talvez seja a preferida dentre as bananas cultivadas no país (MEDINA, 1978).

Ainda segundo MEDINA (1978) os cultivares Nanica e - seu mutante de porte mais elevado Nanicão, são triplóides do grupo AAA (subgrupo Cavendish). Na bananeira Nanica, o pseudocaule mede de 1,20 a 2 metros de altura por 15-25 cm de diâmetro, é de cor verde-brilhante a roxo-parda com numerosas máculas de cor pardo-amarela a escuro. Folhas de cor verde-escuro na face superior, verde mais claro na inferior. Peciolo grosso, curto. Inflorescência pêndula. O cacho pesa, em média, cerca de 25 quilos e o número de frutos varia de 126 - 214. As bananeiras pertencentes ao cultivar Nanicão, foram originadas por mutação do "Nanica" e assemelham-se a ela, porém são de porte maior, atingindo 2,2 a $3,2 \mathrm{~m}$ de altura. Os cachos pesam de 15 a $45 \mathrm{~kg}$ e medem de 0,5 a $1,2 \mathrm{~m}$. Fruto médio a grande, de 18 a $24 \mathrm{~cm}$, de excelente sabor.

o cultivar Grand Naine (grupo AAA) também pertence ao subgrupo Cavendish, possue boas caracteristicas quanto à produtividade e qualidade de fruto, sendo semelhante ao cultivar Nanicão. Os cultivares pertencentes a este subgrupo são resistentes às raças 1 e 2 do Fusarium,e são a nivel mundial, os clones de maior cultivo e importância comercial. 


\subsection{Aspectos genéticos}

A familia Musaceae, um membro da ordem Scitaminae, subdivisão Monocotyledoneae compreende três subfamilias (Musoideae, Strelitzoideae e Heliconoideae). A primeira, caracteriza-se por seus sistemas foliares dispostos em espirais e ter flores unisexuadas, compõe-se de dois gêneros (Musa e Ensete). o gênero Ensete possui distribuição da África Ocidental à Nova Guiné, sendo formado de 7 ou 8 espécies de plantas herbáceas monocárpicas, nenhuma das quais produz frutos comestiveis. Interessam mais como plantas ornamentais.

Ao gênero Musa, que possui entre 24 a 30 espécies, pertencem todos os cultivares produtores de frutos partenocárpicos, com frutos de polpa abundante e a maioria é completamente desprovida de sementes, sendo comestíveis.

As espécies silvestres do gênero Musa, abrangem uma vasta zona intertropical: India até o Nepal, Birmânia, Península da Indochina, Malásia, Indonésia, Filipinas, Nova Guiné e alguns arquipélagos da região leste do Pacífico. Com um número básico de cromossomos 10,11, ou 14 as espécies do gênero Musa são agrupadas em quatro seções de acordo com o APENDICE 3 (STOVER \& SIMMONDS, 1987).

As espécies das seções Callimusa e Rodochlamys, com 5 a 6 espécies cada uma, segundo SIMMONDS (1966) e STOVER \& SIMMONDS (1987), são apenas de interesse ornamental. 
$\mathrm{Na}$ seção Australimusa, que compreende 5 espécies válidas e uma incerta, apenas uma delas de interesse econômico, é utilizada para a extração de fibras nas Filipinas, esp. Musa textilis Nee, outras são utilizadas na alimentação após cozimento em Samoa.

A seção Eumusa (ou simplesmente Musa), com 5 espécies de distribuição geográfica mais ampla, é a que nais de perto interessa, pois a ela estão vinculados todos os cultivares de frutos partenocárpicos de importância econômica que se conhecem no mundo. Das espécies desta seção a mais importante é, sem dúvida, a Musa acuminata Colla, porque foi ela a origem de todas as bananeiras de frutos comestiveis, quer sozinha, quer com a participação de outra espécie dessa seção, a Musa balbisiana Colla.

Musa acuminata colla, é uma espécie polimorfa, com uma vasta área de distribuição, desde as ilhas samoa ao sul da India, passa também pelas ilhas da Indonésia e as Peninsulas da Indochina e Malásia. Musa balbisiana colla, apresenta poucas variações, estando distribuida pela fndia, Birmânia e Filipinas (STOVER \& SIMMONDS, 1987).

o sistema de classificação atualmente adotado para as bananeiras de frutos comestiveis ou partenocárpicos (cultivares de Musa) baseia-se no trabalho de simmonds \& Shepherd ${ }^{3}$, citados por STOVER \& SIMMONDS (1987), que utilizaram um método de notas para indicar as contribuições relativas das duas espécies selvagens ( $M$.

3 SIMMONDS, N.W. \& SHEPHERD, K. The taxonomy and origins of the cultivated bananas. Journal Linnean Society London Botany, London, 55: 302-12, 1955. 
acuminata e M. balbisiana) na constituição genética de diversos cultivares. Utilizando-se de 15 caracteristicas, cada uma das quais com algum grau de diferença diagnosticável entre as duas espécies, demonstraram que as espécies contribuiram de forma bastante definida. Para cada característica em que o cultivar concordava com aquele de M. acuminata selvagem era dada a nota 1; para cada caracteristica em que o cultivar concordava com $M$. balbisiana era dada a nota 5; e, às expressões intermediárias da característica, eram atribuidas as notas 2,3 ou 4 , conforme o grau de sua intensidade.

Essa técnica de nota determina uma amplitude de notas totais de 15 (isto é, 15 vezes 1) para M. acuminata a 75 (isto é, 15 vezes 5) para M. balbisiana. Portanto, quanto mais alta a nota total, maior a contribuição de $M$. balbisiana na origem do cultigeno. Esse esquema é algo complicado pela poliploidia. As bananas comestiveis pertencentes à seção Eumusa têm 22,33 ou 44 cromossomos. Como o número básico de cromossomos nesta seção é n=11, então os cultivares correspondentes àqueles números são respectivamente diplóides, triplóides e tetraplóides. Os cultivares triplóides são geralmente os mais numerosos, os diplóides algo menos e os tetraplóides muito raros. As bananeiras comestiveis da seção Eumusa estão agrupadas em chave de classificação com base na ploidia e através de notas, que mostram a composição genômica em relação às duas espécies genitoras, como mostra o APENDICE 4.

Dos sete grupos que se conhecem existir em cultura, dois deles ( $A B$ e $A B B B$ ) são raros e sem importância; um deles ( $A A A A$ ) 
é de origem artificial recente. Na realidade, são grupos triplóides como acuminata $A A A$ e o triplóide híbrido natural AAB que apresentam interesse comercial, pois neles se encontram os principais cultivares de bananeira de frutos comestiveis plantados no mundo. Simmonds \& Shepherd ${ }^{4}$ citados por SHEPHERD (1984b), sugeriram a ocorrência de partenocarpia, durante o processo de evolução das formas comestiveis de bananeira, esta veio acompanhada de alguma esterilidade feminina atraves de mutações dando origem à M. acuminata (AA). Através de cruzamentos espontâneos desta espécie selvagem com M. balbisiana surgiram os híbridos ( $A B$ ), a partir de cruzamentos com pais ( $A A$ ) ou (BB) surgiram os hibridos $A A A, A A B$ e $A B B ;$ como também as formas raras $A A A A, A A A B, A A B B$ e $A B B B$. As diversificações dos cultivares básicos ocorreram por meio de mutações somáticas.

\subsection{Principais problemas da cultura}

Os principais problemas encontrados para a produção atual e futura da bananeira são as doenças, pragas e características agronômicas indesejáveis, os quais devem ser priorizados nos programas de melhoramento (PERSLEY \& DE LANGHE, 1987). Busca-se também a nivel de cultivar melhores caracteristicas para

4 SIMMONDS, N.W. \& SHEPHERD, K. The taxonomy and origins of the cultivated bananas. Journal of the Linnean society of Botany, London, 55: 302-12, 1955. 
arquitetura da planta, padrão de cacho e de frutos, aceitabilidade comercial e manuseio de pós colheita.

Dentre os problemas fitossanitários, destacam-se a Fusariose, o Mal-de-sigatoka (amarela, rajado negro das folhas e negra), o Moko (ou Murcha Bacteriana da bananeira), viroses, broca (ou "Moleque da Bananeira"), nematóides, traça, doenças do pós colheita (podridão do engaço, podridão da coroa, antracnose), etc. Embora sejam várias as enfermidades que afetam a cultura, são as três primeiras as que provocam maior preocupação à nível mundial, devido à dificuldade de controle e à drástica redução na produção dos bananais.

- Mal-de-sigatoka ou mancha foliar envolve três patógenos intimamente relacionados, Mycosphaerella musicola Leach (ex Mulder), que causa a sigatoka identificada pela primeira vez em Java em 1902, Mycosphaerella fijiensis Morelet, que causa o rajado preto das folhas, descrito em Fiji, em 1964 e a Mycosphaerella fijiensis var. difformis, que causa a sigatoka negra descoberta em Honduras em 1972. O seu aspecto diferiu das demais devido a coloração mais escura das manchas. O termo Sigatoka Amarela se refere à Mycosphaerella musicola e surgiu na América central mas deve ser evitado (STOVER, 1980).

De acordo com MARTINEZ (1986) estes patógenos, intimamente relacionados entre $\mathrm{si}$, apresentam sintomas muito semelhantes de dificil distinção em condições de campo, pois a maior diferença está na coloração e quantidade de estrias. 
Segundo STOVER (1970) a produção conidial foi maior na superficie inferior que na superior das folhas atacadas e começa quando a lesão causada por Mycosphaerella musicola torna-se de marrom pálido a marrom escuro ou preto, a esporulação conidial cessa ou começa a diminuir à medida que o centro da mancha começa a ficar cinza. Uma média de 5,3 colheitas de conidios foram produzidos por mancha em plantas jovens. A esporulação ocorreu em noites suscessivas na ausência de chuvas, durante a ocorrência de orvalho.

A Sigatoka Negra e o Rajado Negro das folhas não foram ainda detectadas no Brasil. Quanto à Sigatoka Amarela as práticas culturais visando o seu controle, mostram-se nulas ou insuficientes. Com relação às variedades resistentes, as comerciais do subgrupo Cavendish (AAA) de que se dispõe são susceptíveis, nas variedades do grupo $A A B$, a Mysore e Prata apresentam moderada resistência (MARTINEZ, 1986).

Todos os clones AAA comestiveis são altamente susceptiveis, e os plátanos AAB possuem alguma resistência. Para $M$. fijiensis observou-se a mesma tendência sendo que a susceptibilidade dos cultivares $A A B$ aumentou, permanecendo alguns plátanos $A A B$ moderadamente resistentes. Alguns clones diplóides e tetraplóides possuem elevada resistência à Sigatoka Negra e busca-se transferir resistência para os plátanos AAB (STOVER,1980).

FOURE et al. (1990) estudaram a susceptibilidade à Sigatoka Negra em mais de 50 plantas de Musa pertencendo a vários grupos genéticos, sob condições de infecção natural com elevada 
pressão de inóculo. Foram encontrados caracteres que determinam resistência parcial e pronunciada resistência em 34 cultivares, um grande número dos quais eram diplóides selvagens. A fertilidade destas bananeiras capacitam o estudo sobre o determinismo da resistência pelo uso deles como parentais em estudos genéticos (hibridação, estudos de progênie, etc.).

Diversas sub-espécies de Musa acuminata selvagem diploides possuem elevados níveis de resistência à sigatoka Negra, e têm sido utilizadas em cruzamentos designados para obtenção de Iinhagens mais produtivas e que possam ser utilizadas em cruzamentos como uma fonte alternativa de resistência à sigatoka Negra (ROWE \& ROSALES, 1989).

Atualmente, moderado a bom controle da doença tem sido obtido pela pulverização regular com emulsões à base de óleofungicida e água, ou óleo somente. Entretanto a pulverização encarece a produção e sempre há o risco de que a doença se torne epidêmica por falha na aplicação do controle. Um possivel método alternativo de combater a doença é a obtenção de cultivares resistentes à infeç̧ão com M. fijiensis (MEREDITH \& LAWRENCE, 1970) É conhecido que em doença de planta onde existe um estreito relacionamento entre patógeno/hospedeiro, ocorre grande dependência do patógeno em relação ao hospedeiro. Portanto doenças especificas são encontradas usualmente no centro de origem das hospedeiras. Isto é verdade quando se trata de Hemileia vastatrix em café, ou mesmo a Sigatoka em Musa, a qual tem estado presente 
por um longo tempo no Pacifico Sul e sudeste da Ásia, centro de evolução das bananas e plátanos (SIMMONDS, 1966).

A Fusariose ou Mal-do-Panamá, constatada pela primeira vez em 1904, no Panamá, é causado pelo Fusarium oxysporum f. sp. cubense, é a moléstia mais importante das bananeiras não incluidas aquelas do subgrupo Cavendish, que são até o momento imunes às raças 1 e 2 do fungo. Os cultivares Ouro, Prata, Maça e Gross Michel são altamente susceptiveis à moléstia (MARTINEZ, 1986).

A raça 1 do patógeno encontra-se dispersa por todo - mundo praticamente e é mais séria economicamente uma vez que afeta cultivares preferidos comercialmente por muitos paises. Já a raça 2 ataca somente híbridos triplóides $B$ luggoe $A B B$ e é endêmica para a América Central (SU et al., 1986).

WAITE (1963) constatou a ocorrência da raça 3 do Fusarium oxysporum f.sp. cubense, em especies selvagens de Helliconia spp. na América Central. Observou-se que espécies selvagens (helicônias) podem albergar patógenos que posteriormente atacam as bananeiras, no caso da fusariose a Heliconia caribaea era hospedeira do fungo, sendo que as helicônias podem transmitir mais doenças para as bananeiras e plátanos (LEHMANN-DANZINGER (1986) . SUN \& KO (1978) isolaram em meio de cultura o que pode ser uma nova raça do fungo (raça 4) que poderá atacar os cultivares pertencentes ao subgrupo Cavendish, até o momento considerados resistentes. Este subgrupo, julgava-se possuir ampla 
resistência (horizontal, poligênica) para a fusariose, entretanto, a ocorrência da nova raça e a demonstração da interação do cultivar com o isolado sugere que a resistência deve possuir um significativo componente vertical. Uma ampla resistência, a qual fornece a variação no grau de ataque da susceptibilidade à resistência, somente está presente se não existe interação diferencial entre genótipos do hospedeiro e do patógeno. o componente vertical nos clones Cavendish é aparentemente influenciado significativamente pelo ambiente e nivel populacional do patógeno, o que talvez venha a explicar a ocasional quebra na resistência para as raças 1 e 2 (PEGG \& LANGDON, 1987).

De acordo com PEGG \& LANGDON (1987) diversos nomes têm sido aplicados para esta doença. O nome de Mal do Panamá foi derivado do país da América central onde pela primeira vez a doença tornou-se epidêmica. Como várias raças têm atacado um grande número de cultivares por todo o mundo o termo mais adequado é doença do Fusarium ou Fusariose.

No Brasil, a primeira citação à moléstia deu-se em 1930 no município de Piracicaba, são Paulo, no cultivar Maçã, sendo que atualmente a raça 1 do fungo se encontra disseminada por todo território nacional, porém ainda pouco se sabe sobre a susceptibilidade dos cultivares existentes no Brasil às demais raças do fungo (APENDICE 5).

- fungo desenvolve-se no sistema vascular da bananeira, após ter infestado as radicelas e o patógeno ter invadido o rizoma, causando gradativamente, o depauperamento da 
planta e a sua morte. Os sintomas iniciam-se pelas folnas mais externas e baixas que exibem um amarelecimento progressivo e rápido da borda para a nervura principal; dentro de poucos dias, as folnas murcham, secam e se quebram na junção do pseudocaule, ficando pendentes. Essas características vão manifestando-se nas folhas mais centrais, portanto mais jovens, até chegar a folha mais central e última. Quanto aos tecidos internos do rizoma e pseudo caule, tornam-se gradualmente pardo-amarelados até a necrose, algumas vezes os sintomas são acompanhados de rachaduras no pseudo caule, junto ao colo da planta (MARTINEZ, 1986).

A Fusariose da bananeira é uma das doenças mais destrutivas em relação às demais doenças de plantas tropicais. A doença tem causado maiores danos no oeste tropical, particularmente na América Central e Caribe, onde nos anos 40 e 50 quase eliminou toda a produção destinada ao comércio externo. A produção então era baseada no clone Gross Michel, o qual foi substituido eficientemente por cultivares do subgrupo Cavendish, os quais até hoje mantém-se resistentes, embora em outras áreas do globo tenham sido atacados pela raça 4 do fungo, até então desconhecida (PEGG \& LANGDON, 1987).

o controle da moléstia praticamente não é realizado em nosso meio, busca-se plantar mudas sadias em áreas isentas do fungo, o que torna a cultura nômade. Na América central os solos são inundados por 6 a 8 meses para erradicar o fungo, plantando-se mudas sadias após a drenagem. Também recomenda-se o tratamento das mudas com retirada de tecidos afetados e imersão em produtos 
quimicos. A medida preferencial de controle consiste na utilização de cultivares mais tolerantes à doença como aqueles pertencentes ao subgrupo Cavendish, o que nem sempre é possivel, pois cultivares como o Maçã e o Prata, apesar de susceptiveis, são largamente cultivados por produzirem frutos muito apreciados no mercado interno (CHALFOUN \& GODINHO, 1986).

o melhoramento efetivo de Musa para resistencia ao Fusarium oxysporum f.sp. cubense é dificultado pelo pouco conhecimento a cerca da genética da interação patógeno-hospedeiro. E muito provável que tanto genes qualitativos quanto quantitativos estejam envolvidos no governo da expressão da tolerância ou resistência ao patógeno. o que é realmente necessário é o desenvolvimento de processos de seleção e técnicas de triagem que revelarão o sistema da interação genética com implicação para uma resistência duradoura em condições de campo (BUDDENHAGEM, 1987, 1990; e STOVER \& BUDDENHAGEN, 1986$)$.

SUN \& SU (1984) e MENDES et al. (1989) descreveram procedimento que permite, de uma maneira rápida e eficiente, a triagem de um grande número de plantas em casa de vegetação quanto à suscetibilidade à fusariose. No primeiro caso foram utilizadas suspensōes contendo $3 \times 10^{4}$ esporos/ml, nas quais 0 sistema radicular das plântulas foi imerso por 1 minuto e após replantada em substrato adequado, já no último caso, a inoculação foi feita através da rega do solo com a concentração de $5 \times 10^{4}$ esporos/ml, após a realização de ferimentos nas raizes através da escarificação do solo. 
HWANG \& KO (1987) obtiveram plantas de bananeira originadas de micropropagação e utilizaram em área contaminada com a Fusariose, para seleção de possiveis variantes somaclonais resistentes.

A bacteriose da bananeira, moléstia vascular originou-se na América tropical, onde é conhecida pelo nome de "Moko", foi primeiro descrita en 1911 em Trinidade por M.R. Schonburgk em 1849 na Guiana. Desde então, só recentemente a doença tem sido indicada fora das Américas.

Esta doença já se encontra no Brasil, na região Norte, Estado do Amapá e redondezas (MARTINEz, 1986).

- Moko é causado pela raça 2 da bactéria Pseudomonas solanacearum Smith. Até o momento são conhecidas cinco estirpes patogênicas desta raça, provavelmente oriundas de Heliconia. (CARES, 1988)

Três raças de $P$. solanacearum são conhecidas, mas somente a raça 2 é patogênica às bananeiras triplóides, plátanos e helicônias. o $P$. solanacearum raça 2 está dividido em três estirpes, SFR, A e B. O SFR é o principal agente causador do Moko nos plátanos $B l u g g o e(A B B)$ nas Américas central e do sul. A sobrevivência do $P$. solanacearum raça 2 para as estirpes $B$ e SFR são indicadas como sendo 12 e 6 meses respectivamente.

- Moko pode ser considerado como a segunda pior doença para as bananeiras e plátanos, atrás somente da sigatoka Negra. Das doenças sistêmicas de Musa é certamente a mais perigosa, 
desde que não tem sido encontrada fonte de resistência entre as variedades comestíveis de bananeiras e plátanos.

Nas plantas adultas, de maneira geral, a doença se manifesta por murcha, amarelecimento e seca das folhas centrais, evoluindo progressivamente para as demais, a folha "vela" é a ülima a sucumbir, e geralmente apodrece sem se desenrolar. Por ser uma doença vascular sistêmica, a murcha bacteriana pode atingir os diversos orgãos da planta desde brotações jovens até plantas em produção, pelos danos que causa, pela facilidade de disseminação e pela dificuldade de controle é hoje um dos mais importantes problemas da bananicultura. A resistência varietal é a alternativa mais promissora e viável para o controle da doença (CARES, 1988).

- controle do Moko inclui o reconhecimento da doença, prevenção da transmissão e destruição das fontes de infecção. Os principais sintomas são, o amarelecimento das folhas começando pelas bordos, murcha, podridão marrom e seca nos frutos e descoloração do sistema vascular do pseudocaule. A transmissão é evitada pela desinfecção das ferramentas e a retirada da inflorescência masculina. Para destruição das plantas infectadas pode-se aplicar injeções com $8,2 \%$ de Glifosate em $5 \mathrm{ml} /$ pseudocaule (LEHMANN-DANZINGER, 1986). 


\subsection{Aspectos do melhoramento da bananeira}

As bananeiras são atacadas por un grande espectro de patógenos incluindo fungos, bacterias, viroses e nematóides. Düversas características agronômicas e da qualidade dos frutos são importantes, e devem ser consideradas como objetivos para o melhoramento. Por exemplo, materiais notaveis con resistencia a doenças têm falhado como cultivares de aceitabilidade comercial devido a problemas de arquitetura de planta, qualidade dos frutos e manuseio de pós colheita. SHEPHERD (1984b) enumerou caracteristicas a serem obtidas em cultivares nacionais (APENDICE 6).

Existe uma falta de entendimento sobre a genética da planta, dos patógenos, de sua interação e co-evolução. A recominação genética nos triplóides partenocárpicos (a maioria dos ciones cultivados) é extremamente diffoil devido a elevada esterilidade e irregularidades meióticas. O melhoramento convencional é wito dificil, durante os últimos 60 anos, os esforços para a produça de novas variedades de aceitação comercial não resultaram em muitos êxitos. Os cultivares de bananeiras e plátanos conhecidos coram selecionados na pré-história (BUDDENHAGEN, 1987).

No passado, as melhores fontes de resistência às doenças foram as espécies silvestres de Musa. Os trabalhos porém encontram dificuldades devido ao alto grau de esterilidade das bananeiras triplóides. O aproveitamento desta fonte de resistencia é dificil e os resultados só se observam a longo prazo. 
considerando-se que a diversidade nas especies de bananeira foi originada, em grande parte, através de mutações espontâneas, é logico pensar que o uso de agentes mutagênicos poderia contribuir para o aumento desta diversidade. Numerosas características podem ser afetadas por mutaçōes somáticas e é certo que muitos cultivares surgiram desta maneira.

\subsubsection{Melhoramento convencional}

- êxito do melhoramento genético de qualquer cultivar depende, entre outros fatores, da amplitude da variabilidade genética disponível ao melhorista. Segundo SHEPHERD (1986) as formas selvagens da espécie Musa acuminata e cultivares do grupo AA, apresentam fonte de resistência para a maioria das doenças de importância.

As bananeiras triplóides com 33 cromossomos $(3 x)$ e as tetraplóides com 44 cromossomos (4x), são geralmente superiores as diploides, com $22(2 x)$, em termos de maiores frutos e produtividade mais elevada. Consequentemente, triplóides e tetraplóides são - alvo do melhorista. A esterilidade é visada como um produto final num programa de hibridação, uma vez que a presença de sementes na fruta seria indesejável comercialmente. Algumas formas de bananeira possuem a capacidade excepcional, de gerar células-ovo viáveis sem meiose tipica, a constituição genômica e genética das mesmas são idênticas à planta mãe e através da fertilização por pólen 
haploide, é posssivel conseguir embrióes e hibridos triploides a partir de mães diplóides ou tetraploides a partir de mães triploides (SHEPHERD, 1984b).

os primeiros passos dos programas convencionais de melhoramento através de cruzamentos em bananeira são hibridação e seleção de recombinantes ao nível diplóide. os diplóides melhorados que apresentam resistência a doenças e diplóides com pólen fértil são então cruzados com os triplóides. Este cruzamento de fêmeas triploides com machos diplóides encontra uma ampla possibilidade de aplicação para bananas de sobremesa AAA e AAB, plátanos $A A B$ e bananas de cozinhar ABB. A fertilidade de tais cruzamentos é usualmente muito baixa; a maioria dos clones polinizados AAA $e$ AAB produzem menos que 0,1 semente por fruto polinizado, enquanto algumas fêmeas ABB produziram mais que 10 sementes por fruto. Segundo SIMMONDS (1962) ocorre uma elevação da fertilidade feminina com a contribuição do genótipo B (Musa balbisiana) para a constituição do parental feminino. Já como parental masculino Musa balbisiana não possuiu êxito, o que indica como caminho para a hibridação a utilização do pólen A de formas AA (SHEPHERD, $1984 \mathrm{~b}$ ). os grãos de pólen funcionais e óvulos de clones diplóides são haplóides; entretanto, muitos dos diplóides comestiveis são ou macho e/ou fêmea estéreis, como por exemplo o cultivar Pisang Mas. Este fenômeno excluiu muitos clones valiosos da hibridação. Diversos diploides formam gametas femininos não reduzidos $(2 n)$ e a hibridação pode resultar em progênies triplóides. Outros clones, por exemplo "SH-2095", são produtores de muito 
pouco pólen, o que limita sua utilidade como parental masculino (NOVAK, 1991).

Para melhoramento das bananeiras de sobremesa tipo exportação, apenas "Gros Michel" e seus variantes mais baixos "Highate" têm sido utilizados como parentais femininos para cruzamento com machos diplóides com resistência a doenças. Esta combinação foi selecionada devido a fertilidade parcial dos parentais femininos, os quais produzem ovulos (3n) não reduzidos, os quais produziram sementes tetraplóides $(4 n)$, após a fertilização com pólen haplóide $(n)$. Muito poucas sementes (aproximadamente uma por cacho) com baixa capacidade de germinação são obtidas e elas produzem plantas com genótipo feminino intacto combinado com o macho haplóide.

Apesar do melhoramento intensivo, o qual incluiu dez mil cruzamentos com "Highgate", nenhum cultivar que seja comercialmente aceitável foi criado. Uma das razões é o uso de somente um parental feminino. Enquanto clones pertencentes ao subgrupo Cavendish seriam muito mais desejaveis como parentais femininos devido a sua resistência à raça 1 do fungo que provoca a fusariose, quase todos os clones apresentam-se fêmea estéreis após polinização (ROWE \& ROSALES, 1989).

Enquanto cruzamentos não podem ser feitos entre triplóides, podem ser feitos entre tetraplóides derivados de triplóides. Os tetraplóides originados de cruzamentos $3 n \times 2 n$ podem combinar produtividade com resistência à doença, mas frequentemente originam plantas muito altas, com um defeito herdado na arquitetura 
foliar (peciolo fraco e recurvado). Eles podem ter importância somente para o consumo local, devido aos seus frutos possuirem baixa qualidade para transporte e baixa aceitabilidade de consumo (ROWE \& ROSALES, 1989 ).

A hibridação em banana é complicada pela combinação de diferentes niveis de poliploidia de parentais associada à formação de gametas femininos não reduzidos. Triplóides secundários podem ser produzidos pelo cruzamento de triplóides primários com diplóides melhorados. ROWE (1984) e STOVER \& BUDDENHAGEN (1986) frisaram a vantagem potencial de tal esquema de melhoramento para superar as caracteristicas indesejáveis dos tetraplóides (folhas curvadas) e incorporar um segundo macho diplóide dentro do processo de recombinação.

A partir de um triplóide primário (3n) cruzado com um parental diplóide, pode-se obter um tetraplóide que novamente cruzado com um diplóide $(2 n)$ dará origem a um triplóide secundário.

Um procedimento alternativo para obtenção de triplóides sintéticos seria induzir a duplicação do número de cromossomos de clones promissores $A A$ ou $A B$ e então fazer cruzamentos: (indução de tetraplóides) $4 \mathrm{n} \times 2 \mathrm{n}$ ou 0 inverso $2 \mathrm{n} \times 4 n$.

Segundo ROWE \& ROSALES (1989) as indicações a respeito dos hibridos secundários de triplóides e tetraplóides não tinham utilidade, e isto permaneceu até muito recentemente, quando foi mostrado que diplóides estão contribuindo como fonte de resistência à doença quando utilizado em cruzamentos com tripló- 
des. Tetraploides têm sido obtidos com produções superiores ao triploide parental. No melhoramento de plátanos, tanto tetraplóides quanto triplóides secundários têm sido selecionados por serem mais produtivos que o parental triplóide original.

Para obtenção de novos hibridos de bananeiras e plátanos para exportação têm-se utilizado triplóides originados de cruzamentos entre $4 n \times 2 n$, podendo-se assim obter frutos de melhor formato e paladar e tentar introduzir caracteres de resistência à Sigatoka Negra.

Normalmente se espera que qualquer novo hibrido para exportação seja útil para o consumo doméstico. Entretanto, as bananeiras e plátanos cultivadas somente para consumo doméstico são mais flexiveis quanto ao formato. Tolerância à baixa fertilidade dos solos, ao estresse devido a ausência de irrígação e à broca são considerações mais importantes.

Dentre os cultivares conhecidos no Brasil os do subgrupo Cavendish são altamente estéreis não produzindo sementes, - que praticamente impossibilita o melhoramento por hibridação; os do subgrupo Prata possuem boas possibilidades para o melhoramento através de hibridação, assim como o Enxerto; os cultivares Mysore, Terra e Terrinha possuiriam problemas como a baixa germinação de sementes; o cultivar Maçã possui muito baixas produção e germinação de sementes o que praticamente inviabilizaria o melhoramento através de métodos convencionais (SHEPHERD, 1984b). 


\subsubsection{Melhoramento não convencional \\ 2.6.2.1. Micropropagaçāo in vitro}

A maioria dos trabalhos com cultura de tecidos que têm sido feitos com o gênero Musa consistem na obtenção de culturas assépticas a partir de ápices caulinares. Tais culturas têm sido estabelecidas para um grande número de clones de bananas de sobremesa ( $A A, A A A$ e $A A B$ ) e plátanos ( $A A B$ e $A B B$ ), utilizando-se meristemas e ápices caulinares (meristema recoberto por poucos primórdios foliares). A multiplicação é feita a partir de ápices caulinares, com aproximadamente $1 \mathrm{~cm}^{3}$ de dimensão, fazendo-se incisōes neste explante para destruição da dominância apical e con isto estimular-se o surgimento de gemas axilares, as quais situamse lateralmente ao ápice meristemático e que normalmente teriam seu desenvolvimento malogrado (DE GUZMAN et al. 1976)

os ápices caulinares possuem o tecido meristemático recoberto por dois a quatro pares de folhas primordiais e, a partir da base dos ápices são formadas gemas adventícias (NovAK et al., 1987)

GUPTA (1986) assim COMO KRIKORIAN \& CRONAUER (1984) utilizaram ápices caulinares de 1 a $2 \mathrm{~mm}$ de diâmetro para recuperação de plantas de bananeira livres de vírus. Explantes com estas dimensôes também têm sido utilizados para a indução de mutaçôes em bananeiras e plátanos (NOVAK et al., 1987). Já WONG (1986) utilizou explantes maiores com aproximadamente $5 \times 8 \mathrm{~mm}$, contendo o ápice caulinar intacto, recoberto por alguns primórdios foliares sobre 
$3 \mathrm{~mm}$ de rizoma.

Para se manter a uniformidade do material cultivado, tem-se trabalhado com explantes iniciais contendo no máximo 1 ou 2 pares de primórdios foliares sobre o meristema e cultivam-se os mesmos até 2 ou $3 \mathrm{~cm}$ de altura, quando então são cortados longitudinalmente pelo centro do apice. Esta tecnica pode ser utilizada também para obtenção de plantas livres de vírus em larga escala, desde que o explante inicial esteja isento do patógeno (KRIKORIAN \& CRONAUER, 1984 ).

LIU et al. (1989), obtiveram 7000 plantas a partir de diversos cultivares de bananeiras e platanos, através de micropropagação e indicaram sua superioridade, quando instaladas em campo, em relação às plantas obtidas convencionalmente.

BERG \& BUSTAMANTE (1974) avaliaram a eficiência do cultivo de meristemas de bananeiras, e sugeriram esta técnica para a eliminação de viroses das plantas cultivadas. As dimensões dos explantes utilizados inicialmente variam grandemente, desde pequenos explantes apicais $(0,3-3,0 \mathrm{~mm})$ até explantes mais avantajados $(10-15 \mathrm{~mm})$. E claro que se o explante inicial for menor, maior será a garantia da eliminação de virus, possivelmente presente. O meio de cultura utilizado normalmente é o de MURASHIGE \& SKOOG (1962).

Com relação à esterilização dos explantes (tais como ápices caulinares, embriōes de espécies diplóides, etc.), tem-se utilizado solução de hipoclorito de sódio $(0,05$ a $0,25 \%)$ com algumas gotas de um espalhante adesivo (tween), sendo o tempo 
variável de acordo com a sensibilidade do explante, para ápices caulinares utiliza-se $5 \mathrm{~min}$, lavando-se a seguir diversas vezes em água destilada estéril para remover todos os traços do agente esterilizante, realizando-se então a inoculação em meio de cultura (CRONAUER-MITRA \& KRIKORIAN, 1986).

- cultivo in vitro da bananeira pode iniciar-se através do cultivo de ápices florais, isto é, ápices caulinares já diferenciados, cultivados em meio MS suplementado com $5,0 \mathrm{mg} / 1$ de BAP (CRONAUER-MITRA \& KRIKORIAN, 1988a) ou 2,5 e 5,0 mg de BAP (BALAKRISHNAMURTHY \& SREE RANGASAMY, 1988).

os meristemas isolados; os quais inicialmente possuem coloração creme, normalmente tornam-se verdes após quatro días. O meio utilizado normalmente é o liquido ou semi sólido, no entanto, observou-se que em meio 1 iquido os brotos crescem mais rápido, enquanto que em meio semi-sólido crescem mais lentamente e produzem brotos únicos (CRONAUER \& KRIKORIAN, 1984b).

CRONAUER-MITRA \& KRIKORIAN (1988C) mostraram diferenças significativas entre cultivares com relação à capacidade de multiplicação em meio de cultura, testando 8 clones diferentes.

Segundo woNG (1986) existe controvérsia a respeito de qual procedimento seria mais adequado, se o ápice caulinar apresentaria maior número de brotações mantendo-se a sua dominância apical ou se removendo-a através de incisões. GUPTA (1986) observou que realizando-se incisões longitudinais no ápice caulinar 6 ou mais vezes ocorria a produção de 6-12 brotos por ápice caulinar e que quando estes eram cortados longitudinalmente e colocados em 
meio fresco poderiam resultar em aproximadamente 20 plantas originadas de um único ápice caulinar.

Segundo WONG (1986) o BAP (6-Benzilaminopurina) permitiu um bom estabelecimento e brotação dos ápices caulinares em bananeira. O autor recomenda a utilização do BAP como citocinina no meio de multiplicação.

GODINHO (1991) notou que com a elevação da concentração de BAP ocorria uma elevação na capacidade de brotação in vivo até certo ponto, após o qual houve uma tendência de decréscimo.

GUPTA (1986) indicou que houve acréscimo na brotação em bananeira com a adição de $0,7 \mathrm{mg} / 1$ até $5,0 \mathrm{mg} / 1$ de BAP, recomendando a sua utilização como citocinina apropriada para a brotação, sendo que a Cinetina não mostrou a mesma eficiência, quando utilizada nas mesmas proporçōes. Por outro lado o autor recomenda a não utilização de elevadas concentrações de reguladores de crescimento, uma vez que podem provocar anormalidades nos cromossomos, provocando variantes somaclonais.

Segundo LAMEIRA (1987) a concentração de BAP ideal para diversos cultivares de bananeira encontra-se em torno de 2,5 $\mathrm{mg} / 1$, enquanto que outras bibliografias indicam de 4,5 a $5,0 \mathrm{mg} / 1$, - que pode indicar diferenças na resposta entre cultivares.

Já BANERJEE \& DE LANGHE (1985) associaram o BAP $(2,30 \mathrm{mg} / 1)$ Com IAA $(0,18 \mathrm{mg} / 1)$ com a finalidade de micropropagar bananeiras e plátanos em condições minimas de crescimento. 
GUPTA (1986) observou a formação de compostos fenólicos os quais oxidavam rapidamente e provocavam a morte do explante. Para evitar esta ocorrência testou ácido citrico, ácido ascórbico e carvâo ativado no meio de cultura adicionados separadamente, sendo que o mais efetivo foi o acido ascórbico filtrado. VUYLSTEKE DE LANGHE (1985) também utilizaram o ácido ascórbico de maneira bem sucedida, obtendo plantas enraizadas a partir de ápices caulinares micropropagados em meio contendo elevadas concentrações de citocinina após 3-4 meses, notou também diferenças entre cultivares quanto à capacidade de produção de brotos.

KRIKORIAN (1990) afirma que de um único ápice caulinar ou floral de bananeira pode-se obter, através da micropropagação, aproximadamente 4 milhões de novas plantas enraizadas em um ano.

A maioria dos trabalhos publicados sobre cultura de ápices caulinares enfatiza a produção de plântulas enraizadas, usualmente por separação de brotos individuais, e transferência dos mesmos para um meio de indução de enraizamento. Entretanto, em alguns trabalnos têm-se cultivado primeiro o explante em meio contendo auxina obtendo-se consecutivamente a formação de parte aérea e raiz. No entanto esta formação de parte aérea e raiz pode ocorrer em brotos muito jovens o que inibe a formação de brotos adicionais. Se o objetivo é a obtenção de muitos brotos deve-se realizar o enraizamento em um passo seguinte (CRONAUER \& KRIKORIAN, $1984 \mathrm{~b})$. 
Segundo WoNG (1986) não foi necessária a adição de auxinas para indução de enraizamento em brotos obtidos em meio contendo BAP como citocinina. VUYLSTEKE \& DE LANGHE (1985) também consideraram desnecessária a adição de auxinas para indução de enraizamento en brotos obtidos em meio contendo BAP como citocinina. Os últimos autores citados, introduziam os brotos com 2 a $3 \mathrm{~cm}$ para meio de enraizamento e quando existia auxina indutora de enraizamento (IBA), o crescimento era reduzido até a paralização. Para a aclimatação os autores transferiram para solo plantas com 6 - $10 \mathrm{~cm}$ de comprimento e sistema radicular com mais de $10 \mathrm{~cm}$ de comprimento de raí, obtendo $100 \%$ de pegamento.

\subsubsection{Eabriogênese somática}

os tecidos de bananeira, bem como de inúmeras outras monocotiledôneas possuem maior dificuldade que as dicotiledôneas, quanto ao comportamento in vitro. Deve-se dedicar uma atenção especial quanto à natureza dos tecidos utilizados para maior facilidade de reorientação da funcionalidade dos mesmos para um sentido desejado, no caso para a embriogênese somática. Para tanto, os tecidos mais indicados são os tecidos jovens, tanto fisiológica como morfologicamente; tais como sementes, tecidos florais ou originados do cultivo in vitro (AMMIRATO, 1984).

Segundo BAKRY (1988) os trabalhos nessa área com a bananeira são ainda poucos e recentes. As metodologias experimen- 
tais en geral são complexas e as vezes dificeis de serem reproduzidas de um cultivar para outro.

A embriogênese somática em cultivares de importância econômica, oferece oportunidade para a obtenção de novos cultivares, sendo que os embriões somáticos podem ser encapsulados, produzindo sementes artificiais. Esta técnica pode contribuir para a propagação da espécie e estocagem in vitro. A suspensão embriogênica representa uma fonte importante de variabilidade genética (variação somaclonal "verdadeira") e, sendo um sistema unicelular, torna-se adequado para induçào e seleção de mutantes. o sistema unicelular capacita a seleção para tolerância ao estresse ambiental e resistência a doenças. Uma suspensão de células embriogênicas é a fonte preferida para protoplastos os quais podem ser utilizados para tratamentos com mutagênicos ou ainda abrir caminhos para introdução de DNA exógeno (ou genes) via transformação celular (NOVAK, 1991).

ESCALAN \& TEISSON (1989) e CRONAUER-MITRA \& KRIKORIAN (1988b) relataram embriogênese somática e regeneração de plantas in vitro em espécies selvagens propagadas por sementes. Este processo constou de obtenção do calo embriogênico derivado destas espécies, através do embrião zigótico jovem, o que infelizmente não pode ser aplicado em cultivares estéreis produtores de frutos para consumo.

SANNASGALA et al. (1990) obtiveram calo embriogênico através de camadas meristemáticas de ápices caulinares altamente proliferativos de dois clones ABB. Estas células 
meristemáticas formaram glóbulos morfogeneticamente competentes em meio líquido que proliferaram e regeneraram plantas via organogênese.

BAKRY \& ROSSIGNOL (1985) recomendam a utilização de tecidos florais de bananeira para indução da embriogênese somática, argumentando que estes tecidos são menos susceptiveis às oxidaçōes devido à menor liberação de fenóis.

NOVAK et al. (1989) induziram a formação de calo através da base da bainha foliar e tecido do rizoma em meio modificado de SCHENK \& HILDEBRANDT (1972), suplementado com ácido 3,6-dicloro-2-metoxibenzóico (Dicamba) em clones $A A, A A A$ e $A B B$. O desenvolvimento de embrióes somáticos foi promovido em meio líquido com zeatina. o mais difícil passo na conversão dos embrióes somáticos em plântulas foi obtido usando um sistema de meio com dupla camada.

\subsubsection{Cultivo de células e obtenção de protoplastos}

A dificuldade de regeneração de plantas inteiras a partir da cultura de células somáticas tem sido o principal fator limitante para a aplicação da genética de células somáticas para o melhoramento da cultura da bananeira. Mesmo técnicas simples de cultivo in vitro como cultura de calo ou suspensão celular têm encontrado certa dificuldade para a cultura da bananeira (KRIKORIAN 
* CRONAUER, 1984). Na suspensão de calo e/ou celular há um número muito grande de células já diferenciadas, não respondendo às condições de cultivo (KRIKORIAN \& SCOTT, 1990). Subcultivós frequentes e seleção rigorosa das porções da suspensão parecem ser - único meio para se estabelecer populações de células totipotentes as quais tornam-se responsivas aos reguladores de crescimento e outros estímulos morfogênicos. Entretanto, isto tem sido obtido em um número limitado de clones de Musa, principalmente com genótipos $A A, A A A$ ou $A B B$, enquanto que resultados positivos em $A A B$ são ainda raros.

DHED'A et al. (1991) obtiveram culturas de suspensão celular para o clone "Bluggoe" (Musa spp., grupo ABB) estabelecidas pelo cultivo de escalpos obtidos pela cultura de meristemas, utilizando meio líquido modificado de MS contendo 5 uM de 2,4-D e 1 uM de zeatina. A regeneração de plantas de culturas de suspensão celular foi adquirida através de quatro passos envolvendo diferentes meios de cultura. Glóbulos embriogênicos formaram-se quando uma suspensão peneirada foi cultivada em meio líquido sem reguladores de crescimento. A adição de citocinina foi essencial para a maturação subsequente e germinação dos glóbulos e resultou na regeneração de plantas na frequência de $10-14,5 \%$. A regeneração de plantas ocorreu através de embriogênese somática, a qual em todos os estágios mostrou notável semelhança morfológica e histológica com a embriogênese zigótica em espécies selvagens de Musa. Embriões somáticos foram produzidos diretamente de células em 
suspensão e não via calo, e as plantas germinadas foram estabelecidas em solo.

Por definição, protoplastos são células com a membrana plasmática, mas sem a parede celular. os fatores mais importantes para o isolamento dos protoplastos são o estado fisiológico dos tecidos e do conteúdo celular, a escolna das enzimas, a composição das soluções e a concentração e tipo do estabilizador osmótico. Uma boa fonte de protoplastos é o mesófilo foliar. o rendimento, viabilidade e qualidade são influenciados substancialmente pela idade da folha como também pelas condições do ambiente, como luz, temperatura, fertilidade do solo e umidade em que as plantas crescem. Os tecidos de calo e suspensão celular são frequentemente utilizados como fonte de protoplastos (GAMBORG et a1., 1981).

KRIKORIAN (1988b) ressalta a necessidade de se buscar tecidos morfogeneticamente competentes para obtenção de protoplastos, isto é, o material biológico certo, e em estágio adequado.

A obtenção de protoplastos de Musa representa potencialmente uma valiosa ferramenta para estudos fisiológicos e trabalhos futuros através de engenharia genética. Poucos autores têm indicado isolamento de protoplastos de maneira bem sucedida. Têm-se utilizado folhas de plantas in vitro ou de casa de vegetação, e segmentos de rizoma de plantas cultivadas in vitro (NovAK, 1991). 


\subsubsection{Variaçāo somaclonal}

Ocasionalmente a multiplicação clonal de algumas espécies pode resultar em alterações de ordem morfológica, estas podem apresentar alterações com relação à textura, cor e taxa de crescimento. Tais alterações, tamber denominadas de variação somaclonal, poden ser isoladas obtendo-se linhagens distintas, as quais podem, posteriormente, apresentar-se reversiveis ou não (STREET, 1973).

Segundo KRIKORIAN (1988a) algumas vezes são obtidos percentuais de variantes somaclonais acima do aceitável para a produção comercial da bananeira pela simples micropropagação.

E bastante conhecido atualmente, que mudanças morfológicas podem ocorrer no processo de cultura de tecidos, muitas destas mudanças, una vez estabelecidas dentro do genoma de plantas regeneradas, podem ser portanto, transferidas para geraçōes posteriores. Este fenômeno, chamado de variação somaclonal, pode ser definido como variabilidade genética durante a cultura de tecidos (LARKIN \& SCOWCROFT, 1981). A variação genética pode envolver desde mutaçōes em genes únicos, até alterações mais grosseiras, havendo alterações no grau de ploidia.

Os fatores que influenciam a variação somaclonal em bananeiras podem ser intrínsecos e extrínsecos. o primeiro tipo refere-se à estabilidade genética do cultivar ou genótipo cultivado, o segundo fator refere-se aos fatores induzidos sob cultivo (SMITH, 1988). 
As mudanças induzidas durante o processo da cultura de tecidos podem ser influenciadas por seleção do explante, influência do meio de cultura (particularmente a natureza e concentração dos fitormônios), o período gasto em cultura e o grau de diferenciação que os tecidos suportam em cultura.

A variabilidade ou formação dos variantes através da cultura de tecidos de bananeiras tem usualmente sido indicada como indesejável, particularmente do ponto de vista da propagação clonal, entretanto existe potencial para o desenvolvimento de linhagens com melhores níveis de resistência a doenças, além de outras caracteríśticas. HWANG \& KO (1987) utilizaram a variação somaclonal em plantas de bananeira originadas do cultivo de ápices meristemáticos com a finalidade de se obter resistência à Fusariose. A ocorrência de variação somaclonal em plantas de interesse produzidas in vitro, como a bananeira, torna necessária a existência de métodos de seleção rápida para doenças como o Malde-Sigatoka (STOVER, 1987).

\subsubsection{Indução de mutação}

Através da indução de mutações pode-se elevar a variabilidade genética em amplas e homogêneas populações, através da exposição de células de plantas, tecidos ou mesmo plantas à ação de mutagênicos físicos ou químicos. Eles são capazes de elevar a frequência de mudanças no material genético, principalmente quando 
associado a un processo eficiente de seleção dos mutantes (HANDRO, 1981).

SHEPHERD (1983) atribui as mutações somáticas ocorridas espontaneamente à diversificação dos cultivares básicos comestiveis de bananeira (APENDICES 7 e 8 ), também reconhece que muito da diversidade originada durante o processo evolutivo desta especie se deve às mutações. Portanto a utilização de indução de mutações pode elevar a frequência de mutações que ocorrem espontaneamente, o que poderá facilitar a ampliação da base genética desta cultura. Muitas mutações já conhecidas têm efeitos bem óbvios na planta, necessitando pouco ou nenhum critério para evidenciá-los. Sem dúvida, devem existir inúmeros outros, que não podem se revelar, com certeza, sem uma avaliação bem criteriosa. Pensa-se em pequenas diferenças morfológicas ou fisiológicas, inclusive resistência à doenças. Desconhecê-las pode dificultar a busca de mutações úteis, espontâneas ou induzidas, pela seleção clonal SHEPHERD (1983).

A propagação vegetativa de Musa mantém a constituição heterozigótica das formas comestiveis. Esta natureza genética é adequada para a aplicação do melhoramento por indução de mutações uma vez que plantas triplóides são inevitavelmente mais, ou menos estéreis devido ao desequilibrio da sua meiose (SHEPHERD, $1984 b)$.

o estado heterozigótico Aa é esperado nos locos de cultivares diplóides enquanto que os heterozigotos podem existir em duas maneiras diferentes Aa e Aaa em triplóides. A constituição 
heterozigotica de hibridos interespecificos deve ser como segue: $A a B, A a b, A A b, A B b, a B b$ e $a B B$. A indução de mutação pode recuperar um fenótipo recessivo por mutação, inibindo ou deletando o alelo dominante correspondente. Un dos objetivos da indução de mutação é a obtenção de alterações de uma ou poucas características de cultivares de boa aceitação, mas sem a alteração das qualidades pré-existentes. No caso da bananeira, mais especificamente, desejase plantas que combinem boa qualidade de frutos com resistência a doenças (BROERTJES \& VAN HARTEN, 1988). A indução de mutação pode ser particularmente importante para espécies de Musa estéreis, onde não há reprodução sexual que possa gerar variabilidade genética (KRIKORIAN \& CRONAUER, 1984 ).

o principal método seguido no melhoramento através da indução de mutações de frutiferas através do uso da radiação tem sido a irradiação de gemas meristemáticas multicelulares (SPIEGELROY, 1990).

o cultivo de ápices caulinares in vitro tem sido utilizado como um sistema auxiliar aos métodos de melhoramento por indução de mutações em bananeiras e plátanos, as gemas adventícias proliferam-se através da base do ápice caulinar, tais gemas são diferenciadas de uma única ou poucas células de um rizoma irradiado, o que favorece a indução e recuperação de mutantes, como relatado por NOVAK et al., 1987. Neste trabalho, os ápices caulinares, compostos do meristema recoberto por dois pares de primórdios foliares, foram excisados de brotos obtidos a partir do cultivo in vitro de ápices caulinares e a seguir foram irradiados com raios 
gama através de una fonte de ${ }^{60} \mathrm{Co}$. As diferenças de radiossensitividade foram dependentes do nivel de ploidia e constituição híbrida dos genomas A e B. A escolna das doses adequadas para a irradiação dos ápices caulinares de Musa cultivados in vitro foi determinada com base na redução de $50 \%$ de crescimento e no performance morfogenético em relaçāo ao controle não irradiado. As doses recomendadas foram $25 \mathrm{~Gy}$ para as diploides, 35Gy para as triplóides AAA, 40Gy para $A A B$ e $A B B$ e 50 Gy para as tetraplóides AAAA. As brotações foram propagadas até o ciclo vegetativo $\mathrm{M}_{2} \mathrm{~V}_{4}$ e plantas enraizadas foram transplantadas em solo.

Com relação ao uso de mutagênicos quimicos como o Metanossulfonato de Etila (EMS), os ápices caulinares de clones diplóides e triplóides foram obtidos após três horas de incubação com $24,67 \mathrm{mM}$ do mutagênico $(0,2 \%$ ) (OMAR et al., 1989).

NOVAK et al. (1990) obtiveram um mutante, GN-60, a partir da irradiação in vitro de ápices caulinares do cultivar Grand Naine, com raios gama. A planta mutante mostrou diferenças nos zimogramas de proteinas solúveis e isozimas de esterase. A única planta mutante foi micropropagada e está sendo testada em campo em Honduras e Austrália. A indução de mutações somáticas pode contribuir substancialmente para a ampliação da variabilidade genética dentro dos clones de Musa com reprodução vegetativa obrigatória. Este sistema, entretanto, pode também ser importante para o melhoramento de diplóides férteis antes de seu uso em cruzamentos. 
Idealmente, o melhor material para recuperação de mutantes sólidos, seria uma cultura de células, in vitro, com formação de embrióes somáticos, após o tratamento, cada um originário de uma única célula (SHEPHERD, 1986).

A determinação da sensitividade a radiações ou a mutagênicos quimicos a serem utilizados é etapa indispensável na aplicação de mutagênese induzida. Para a determinação da radiossensitividade, no caso de mutagênicos físicos, utilizam-se várias doses sobre plantas ou explantes apropriados, de modo que pode-se elaborar uma curva de resposta às doses de radiação e, a partir dai, com base na sobrevivência, número de perfilhos, dose letal média (LD 50), etc., escolher a dose mais adequada a ser utilizada.

Uma vez que indução de mutações através do uso da radiação se dá normalmente em tecidos de plantas multicelulares, a formação de quimeras e o isolamento dos setores mutados são um sério problema (SPIEGEL-ROY, 1990).

As células encontram-se em atividade fisiológica distinta e não encontram-se no mesmo estágio dentro do ciclo mitótico, é de se supor que ocorram reações diferentes à uma mesma dosagem de radiação (BROERTJES \& VAN HARTEN, 1988).

As células mutadas têm a capacidade de formar uma Iinhagem de células iquais mutadas, desde que a mutação não provoque danos fisiológicos ou genéticos que diminuam a taxa de crescimento e multiplicação (BROERTJES \& VAN HARTEN, 1988). A 
seleção diplôntica ou intrassomática é um tipo de competição entre células vizinhas mutadas e não mutadas, podendo levar à eliminação das células mutadas. Parece lógico supor que as células que sofreram danos fisiológicos ou cromossômicos, apresentem uma menor taxa de divisão e portanto uma menor capacidade mitótica em relação as células que não sofreram estes efeitos. Por outro lado, mutações gênicas simples ou até deleçōes cromossômicas menores não alteram necessariamente a capacidade de competição da célula.

Uma célula mutada, por sua vez, multiplicando-se origina um tecido mutado que difere geneticamente do tecido vegetal de origen. A co-existência de tecidos vegetais geneticamente distintos em um mesmo individuo chama-se quimerismo.

Normalmente distinguem-se três tipos de quimeras, as setoriais, as mericlinais e as periclinais, nos três casos as células mutadas permanecem unidas e ocupam certa área da planta (BROERTJES \& VAN HARTEN, 1978).

Havendo a ocorrência de quimerismo, torna-se necessário isolar o setor mutado, de tal modo que se possa obter um mutante periclinal estável ou um mutante sólido. Para isto são utilizadas técnicas apropriadas de multiplicação e condução através de ciclos de propagação vegetativa, no caso de plantas com este tipo de reprodução.

No caso da cultura da bananeira o número de ciclos de propagação vegetativa necessário para o isolamento dos setores mutados tem variado grandemente. NOVAK et al. (1986) em trabalhos iniciais com ápices caulinares cultivados in vitro, não chegaram a 
definir um número exato de geraçōes após a irradiação, já NovAK et al. (1989) em trabalhos posteriores, sugerem a multiplicação clonal por quatro gerações vegetativas $\left(M_{1} V_{4}\right)$.

A utilização de marcadores bioquímicos seria de grande interesse para a deteção da diversidade genética que ocorre entre os diversos cultivares e formas selvagens de Musa, isto seria importante para a taxonomia, conservação de bancos de germoplasma e para acompanhamento dos programas de melhoramento genético e avaliação de mutantes espontâneos ou induzidos. Porém, embora numerosas tentativas venham sendo feitas para utilizar o polimorfismo isoenzimático como marcadores genéticos, existe muita controvérsia quanto a eficácia deste método para bananeiras e plátanos.

Como já citado anteriormente, NovaK et al. (1990) obtiveram um mutante induzido através de radiação gama em ápices caulinares do cultivar Grand Naine, este mutante de porte anão apresentou diferença no padrão de bandamento em relação ao cultivar inicial, isto se deu para o locus da esterase, e foi interpretado como uma deleção ou inibição de um alelo especifico.

Já Reuvenis citado por NOVAK (1991) não encontraram diferenças entre diferentes clones triplóides (AAA) utilizando diferentes isoenzimas e concluiram que o padrão de isoenzimas não é uma ferramenta adequada para a detecção de mutantes e variantes

5 REUVENI, O.; ISRAELI, Y.; DEGANI, H.; ESHDAT, Y. Genetic variability in banana plants multiplied via in vitro culture. (IBPGR Report on Project, PR3/11). 
somaclonais em populaçōes de bananeiras micropropagadas, porém recomendam a utilização de um vasto espectro de marcadores bioquimicos utilizando proteina solúveis totais. 


\section{MATERIAIS E MÉTODOS}

Esta pesquisa foi conduzida no laboratorio de cultura de tecidos da Seção de Radiogenética do Centro de Energía Nuclear na Agricultura - CENA/USP - Piracicaba-SP, de setembro de 1989 a outubro de 1992. A maioria dos experimentos implantados no presenté trabalho, faz referência a ao cultivar Maçã (grupo AABB). Os experimentos com embriogênese somática e obtenção de protoplastos além deste, basearam-se nos cultivares Nanica e, seu mutante de porte mais elevado, Nanicão (principal cultivar da bananicultura brasileira, pertencente ao grupo AAA) e o clone $G N-60$, mutante de porte anão do "Grand Naine" (grupo AAA) obtido por NovAK et al. (1990) através de indução de mutação com radiação gama.

Os explantes iniciais dos diversos cultivares foram obtidos a partir de campos de produção comercial, excetuando-se o clone GN-60 o qual já se encontrava em multiplicação no laboratório de cultura de tecidos da seção de Radiogenética do CENA. Após trabalhos de desinfecção, inoculação e micropropagação in vitro de ápices caulinares dos diversos clones de bananeira, foram implantados diversos experimentos visando ter conhecimento dos melhores procedimentos a serem adotados para a cultura de tecidos de Musa, de acordo com os objetivos deste trabalho. 
- Experimento 1 buscou comparar a capacidade de brotação de ápices caulinares do cultivar Maçã, extraidos através de cinco maneiras diferentes, enquanto que o Experimento 2 comparou a eficiência dos meios semi-sólido e do líquido com e sem agitação, durante a micropropagação.

Com a finalidade de se comparar a influencia do BAP em diversas concentraçóes para a micropropagação do cultivar Maçã foram realizados os Experimentos 3 e 4 e para se verificar qual regulador de crescimento e em qual concentração utilizar para enraizamento de plântulas de bananeira, usou-se no Experimento 5 o IAA, IBA e o NAA em diferentes concentrações.

Uma vez que buscou-se ampliar a variabilidade genética do cultivar Maçã, visando-se obter resistência à Fusariose, foram instalados os Experimentos 6 e 7 , que tiveram a finalidade de se conhecer a radiossensitividade dos ápices caulinares do cultivar Maçã a raios gama, comparando os efeitos através de contagens e pesagens do numero de brotos após irradiação.

os explantes irradiados, constituidos de tecidos multicelulares e portanto sujeitos ao quimerismo, foram então, subcultivados por quatro geraçōes vegetativas para isolamento dos setores mutados, as plântulas obtidas então, foram aclimatadas em solo e levados para a casa de vegetação, para posterior seleçāo com suspensão de esporos do Fusarium oxysporum f.sp. cubense.

Com a finalidade de inoculação e seleção das plantas em casa de vegetação, foi necessário o isolamento do fungo e seu cultivo em meio apropriado, foi então realizado o Experimento 8 
visando obter conhecimento sobre o tempo ideal de cultivo do fungo en BDA para a produção de um maior número de esporos para inoculações posteriores. A inoculação e avaliação das respostas apresentadas pelas plantas do cultivar Maçã foi realizada através do Experimento 9 .

As plantas obtidas após irradiação e subcultivo por quatro gerações vegetativas, foram observadas para verificação de alterações fenotipicas ocorridas in vitro e em casa de vegetação, - Experimento 10 constou da quantificação e avaliação das alteraçóes visivelmente perceptiveis, em casa de vegetação, das plantas de bananeira "Maçâ", originadas de ápices caulinares não irradiados (avaliação da variação somaclonal) e irradiados (avaliação das possiveis mutações induzidas).

A obtenção de embriões somáticos em Musa possue muito interesse para a ampliação da sua variabilidade genética, através da variação somaclonal inerente ao processo ou indução de mutação. Deste modo, o Experimento 11 teve como finalidade a indução de estruturas embriogênicas em segmentos do rizoma e pseudocaule dos cultivares Maçã, Nanicão e Grand Naine (clone GN-60), através da utilização de diversas concentraçōes do regulador de crescimento Dicamba, observando também os niveis de oxidação, dimensões e posições adequadas dos explantes. No Experimento 12 buscou-se observar a influência da concentração de sacarose para a formação destas estruturas embriogênicas. As estruturas embriogênicas obtidas foram cultivadas em meio líquido sob elevada rotação das quais foram obtidas suspensões celulares e 
estruturas globulares, as mesmas foram colocadas para desenvolvimento na ausência de reguladores de crescimento e postas para germinar em meio contendo dupla fase, uma sólida contendo carvão ativado e uma líquida contendo zeatina (Experimento 13 ).

A partir de suspensōes celulares originadas das estruturas embriogênicas obtidas, foram realizados trabalhos visando o isolamento de protoplastos (Experimento 14).

3.1. Obtenção e cultivo de eristenas iniciais de plantas do campo, obtidos a partir de ápices vegetativos ou florais

Plantas jovens de Musa foram obtidas a partir de campo de produção comercial, as quais não haviam sofrido frutificaf̧ão; 27 do cultivar Maçã e 18 do cultivar Nanicão. Estas plantas foram trazidas à seção de Radiogenética do CENA, onde foram efetuados cortes no pseudocaule aproximadamente $20 \mathrm{~cm}$ acima do rizoma. Os rizomas foram lavados em água, eliminando-se a terra e as raizes. A seguir, as bainhas foliares que ainda restaram no pseudocaule, foram retiradas gradativamente, ao passo que o rizoma sofreu cortes sucessivos, até que 0 explante adquiriu $2,5 \mathrm{~cm}$ de diâmetro e $5 \mathrm{~cm}$ de comprimento, mantendo em seu interior o ápice meristemático intocado.

Estes explantes foram imersos em álcool $95^{\circ} \mathrm{GL}$ por 5 minutos para a esterilização e quebra da tensão superficial, logo 
após foram transferidos para solução de hipoclorito de sodio (produto comercial $5 \%$ cloro ativo - Q'Boa) diluío na proporção 1:3, por 20 minutos em agitador, para completar a esterilização superficial. A seguir foram tratados em câmara asséptica, onde sofreram 4 lavagens em água destilada esteril (autoclavada).

Após este tratamento, com o auxilio de bisturi, foram deixados no explante apenas 3 ou 4 primórdios foliares recobrindo o meristema apical, ficando o explante com aproximadamente $2,0 \mathrm{~mm}$ de diâmetro. Nestas condiçōes os explantes foram inoculados em meio de cultura semi-sólido ou liquido, contendo sais minerais de MURASHIGE \& SKOOG (1962) (MS), macro e micronutrientes, vitaminas de MOREL \& WETMORE (1951) (MW), suplementado com 5,0 mg/1 de BAP, $3 \%$ sacarose, $\mathrm{pH} 5,7-5,8$ e para solidificação utilizou-se $6,5 \mathrm{~g} / 1$ de ágar.

os explantes foram incubados em sala de crescimento com temperatura controlada $\left(26^{\circ} \mathrm{C} \pm 2^{\circ} \mathrm{C}\right)$ e sob condiçōes de 16 horas de luz (intensidade luminosa de $25 \mathrm{w} / \mathrm{m}^{2}$ ). As trocas de meio foram realizadas a cada 15 dias.

Para efeito de comparação das dimensões mais adequadas para o cultivo de ápices caulinares, inoculou-se também explantes medindo aproximadamente $1 \mathrm{~cm}^{3}$.

Os explantes iniciais do cultivar Nanica, foram obtidos a partir de "corações" extraidos do cacho de 6 plantas em campo pertencentes a este cultivar. Através de cortes sucessivos para a eliminação das brácteas e verticilios florais masculinos no ápice da raqui, quando os explantes adquiriram as dimensões de 
aproximadamente $3 \mathrm{~cm}^{3}$ foram então tratados de maneira semeinante ao já explicado anteriormente para desinfeção dos ápices caulinares de bananeira pertencentes aos cultivares Maçã e Nanicão. Quando se obteve em câmara asséptica meristemas apicais destas inflorescências com aproximadamente $0,5 \mathrm{~cm}^{3}$, estes foram inoculados em meio de cultura semelhante ao utilizado para os ápices caulinares.

Além dos cultivares Maçã, Nanica e Nanicão, trabaIhou-se ainda com o clone GN-60. Plantas deste material, mantidas em micropropagação no laboratório de cultura de tecidos da Seção de Radiogenética do CENA, serviram de fonte para os experimentos envolvendo embriogênese somática.

3.1.1. Capacidade de brotação de ápices caulinares extraídos de diferentes meiras

A multiplicação clonal in vitro da bananeira assim como de diversas outras culturas é feita com a utilização de ápices caulinares, os quais contém tecidos meristemáticos.

A utilização de ápices caulinares de banana (Musa sp.) cultivar Maçã (grupo $A A B$ ) para a multiplicação in vitro tem sido feita com frequência na seção de Radiogenética do CENA com a finalidade de indução de variabilidade genética através do uso de raios gama. Estes ápices caulinares consistem na região apical do 
rizoma da planta contendo a região meristemática, recoberta pelos primórdios foliares mais 4 - 5 bainhas foliares.

o uso de ápices caulinares onde a região meristemática se encontra recoberta por 2 - 4 pares de primórdios foliares e onde o explante possui em torno de $0,5 \mathrm{~mm}$ de diâmetro, é recomendado para o estabelecimento da cultura proveniente do campo para a condição in vitro, uma vez que diminui a possibilidade de contaminações através de microrganismos exógenos e endógenos.

Quando a cultura já se encontra estabelecida in vitro, estando Iivre de microrganismos, permite o uso de tecidos maiores com menor risco de contaminações e de multiplicação de materiais indesejáveis. Durante o processo de micropropagação, multiplica-se as plântulas através da separação dos brotos formados e de sua re-inoculação em meio de cultura, porém para fins de indução de mutação, onde o explante inicial para tratamento com mutagênico deve ser padronizado, este procedimento não seria adequado.

Além disso, o ápice caulinar nas bananeiras além do meristema apical possui meristemas laterais contidos nas gemas opostas às folhas, e estas também podem contribuir para a regeneração de brotos em meio de cultura.

Como no presente trabalho interessa uma brotação elevada e em tempo relativamente curto, instalou-se experimento com a finalidade de se estimar qual o tipo de ápice caulinar seria mais qualificado para uma brotação mais eficiente (Experimento 1). Foram eleitos 5 possiveis tipos de ápices caulinares (ilustrados pela 
Figura 1), os quais foram comparados com base na sua capacidade de brotação in vitro. Cada um dos cinco tratamentos (tipos de explantes) contou com 15 repetições, sendo que cada repetição correspondeu a um ápice caulinar, o qual foi inoculado individualmente em Erlenmeyer ( $250 \mathrm{ml}$ ) com $50 \mathrm{ml}$ de meio líquido contendo a seguinte composição: macro e micronutrientes de MS, vitaminas de MW, $5,0 \mathrm{mg} / 1$ de BAP, $3 \frac{8}{6}$ sacarose, $\mathrm{pH} 5,7-5,8$.

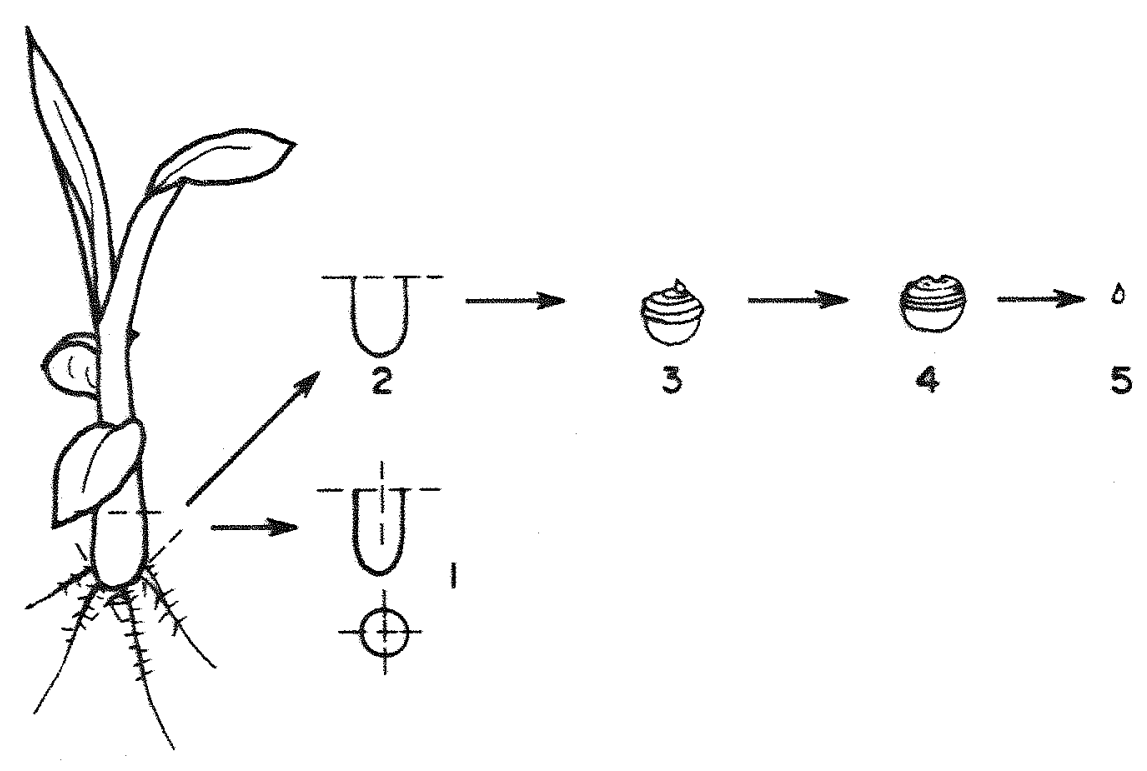

Figura 1 - Desenho ilustrativo de uma planta enraizada in vitro, da qual é possível o re-isolamento de ápices caulinares. os números indicam 5 tipos diferentes de explantes. 
1. Apice caulinar com $0,7 \mathrm{~cm}$ de diametro basal por $1 \mathrm{~cm}$ de comprimento, contendo o meristema apical mais gemas laterais sem a remoção das bainhas foliares e que sofreu dois cortes perpendiculares longitudinalmente até a altura do meristema.

2. Ápice caulinar com $0,7 \mathrm{~cm}$ de diâmetro basal por $1 \mathrm{~cm}$ de comprimento, contendo o meristema apical mais gemas laterais sem a remoção das bainhas foliares.

3. Apice caulinar com 0,7 cm de diametro basal por $1 \mathrm{~cm}$ de comprimento que sofreu renoção das bainhas foliares, contendo no entanto, o meristema apical mais as gemas laterais.

4. Ápice caulinar com $0,7 \mathrm{~cm}$ de diametro basal por $1 \mathrm{~cm}$ de altura, contendo apenas as gemas laterais, uma vez que a que determinava a dominância apical foi removida.

5. Ápice caulinar com 0,1-0,2 cm de diametro, compreendendo a região meristemática contendo 2 - 3 primórdios foliares.

Os explantes foram levados para sala de crescimento com temperatura controlada $\left(26^{\circ} \mathrm{C} \pm 2^{\circ} \mathrm{C}\right)$ e fotoperiodo de 16 horas de luz continua (intensidade luminosa de $38 \mathrm{w} / \mathrm{m}^{2}$ ) e 8 horas de escuro, e mantidos sob agitação em agitador rotativo a 65 rpm, sendo que a avaliação foi realizada através da contagem simples do número de brotos obtidos após 30 dias da inoculação. A análise estatistica foi realizada atraves da análise de variancia e foi utilizado o Teste de Tukey para as médias transformadas segundo $\left(x+\frac{1}{2}\right)$. 


\subsubsection{Comparação de meio líquido com e sem agitação com meio semi-solido}

com a finalidade de se comparar as respostas dos ápices caulinares quando inoculados em meio semi-sólido ou em meio Iiquido (com e sem agitaça) para o estrmulo das brotaçóes em ápices caulinares de bananeira "Maçã", foi instalado o Experimento 2; este constou de 48 plantas estabelecidas in vitro, das quais foram extraidos os ápices caulinares com aproximadamente $0,7 \mathrm{~cm}$ de diâmetro basal por $1,0 \mathrm{~cm}$ de altura (explante número 2 da Figura 1).

Foram inoculados em meio semi-sólido, líquido com agitação e líquido sem agitação, contendo a seguinte composição: macro e micronutrientes de MS, vitaminas de MW, 3\% sacarose, pH 5,7 $-5,8$. $\operatorname{BAP}(5,0 \mathrm{mg} / 1)$. O delineamento adotado foi o inteiramente casualizado, sendo que cada tratamento contou com 16 repetições (ápices caulinares).

os explantes foram levados para sala de crescimento com temperatura controlada $\left(26^{\circ} \mathrm{C} \pm 2^{\circ} \mathrm{C}\right)$ e sob condições de 16 horas de luz (intensidade luminosa de $38 \mathrm{w} / \mathrm{m}^{2}$ ). Os ápices caulinares que receberam o tratamento utilizando meio liquido com agitação, foram mantidos sob agitação em agitador rotativo a $65 \mathrm{rpm}$. Os ápices caulinares que receberam o tratamento com meio liquido sem agitação e os ápices caulinares inoculados em meio semi-sólido, foram mantidos sob a mesma intensidade luminosa, porém estáticos. 
A avaliação foi realizada através da contagem simples do número de brotos obtidos após 20 dias da inoculação. A análise estatística foi realizada através da análise de variancia e foi utilizado o Teste de Tukey para as médias transformadas segundo $\sqrt{\left(x+\frac{1}{2}\right)}$.

\subsubsection{Influência do BAP na brotação de ápices caulinares}

Devido a controvérsia existente entre as referências bibliográficas, sobre as melhores concentrações de BAP a serem utilizadas para a micropropagação da bananeira e devido haver respostas diferenciadas entre cultivares distintos de Musa, foram realizados 2 experimentos para determinação das melhores concentrações de BAP para a indução de brotação em bananeira "Maçã".

o primeiro destes (Experimento 3) possuiu delineamento inteiramente casualizado e contou com 4 tratamentos, envolvendo as concentraçóes de $0 ; 2,5 ; 5,0$ e $7,5 \mathrm{mg} / 1$ de BAP, sendo que cada tratamento contou com 32 repetições (ápices caulinares representados pelo tipo 2 na Figura 1), perfazendo um total de 128 plantas utilizadas.

Os explantes foram inoculados em meio de cultura semi-sólido de MS, macro e micronutrientes, vitaminas de MW, suplementado com as diversas concentrações de BAP, 3\% sacarose, $\mathrm{pH}$ $5,7-5,8,1,5 \mathrm{~g} / 1$ de gel (phytagel - sigma). Foram a seguir 
levados para sala com temperatura controlada entre $26-27^{\circ} \mathrm{C}$ e sob 16 horas de 1 uz $\left(25 \mathrm{~W} / \mathrm{m}^{2}\right)$ e 8 de escuro. A avaliação foi realizada através do número de brotos emitidos através do tempo (apos 40 dias).

A análise estatistica foi realizada através da análise de variancia e foi utilizado o Teste de Tukey para as médias transformadas segundo $\sqrt{ }\left(x+\frac{1}{2}\right)$.

Devido aos resultados do Experimento 3, foi realizado um segundo experimento (Experimento 4). As concentrações de BAP foram de $0 ; 2,5 ; 5,0 ; 7,5 ; 10,0 ; 12,5 ; 15,0 ; 17,5$ e $20,0 \mathrm{mg} / 1$. O delineamento foi inteiramente casualizado, e cada tratamento contou com 16 repeticões, contendo parcelas com dois ápices caulinares cada uma. A avaliação foi feita sobre o peso e número médios de brotos originados por parcela.

Os explantes utilizados para este experimento foram obtidos a partir de 144 plantas cultivadas in vitro com aproximadamente $7,0 \mathrm{~cm}$ de altura e $0,7 \mathrm{~cm}$ de largura basal, mantidas na condição estéril (in vitro). En câmara asséptica, foi realizado o corte de parte aérea 1,0 cm acima do rizoma com o auxilio de pinça e bisturi flambados, retirando-se tambem possiveis raizes presentes (ápice caulinar representado pelo número 2 na Figura 1 ).

os explantes foram inoculados en meio de cultura semi-sólido de MS, macro e micronutrientes, vitaminas de Mw, suplementado com as diversas concentrações de BAP, 3\% sacarose, $\mathrm{pH}^{\circ}$ $5,7-5,8,1,5 \mathrm{~g} / 1$ de gel (phytagel - Sigma). Foram a seguir 
levados para sala com temperatura controlada entre $26-27^{\circ} \mathrm{C}$ e sob 16 horas de 1 uz $\left(25 \mathrm{~W} / \mathrm{m}^{2}\right)$ e 8 de escuro. A avaliação foi realizada através do peso e número médio de brotos emitidos através do tempo (após 45 dias).

A análise estatistica foi realizada através da análise de variancia e foi utilizado o Teste de Tukey para as médias transformadas segundo $\sqrt{ }\left(x+\frac{1}{2}\right)$.

\subsubsection{Indução de enraizamento de plantulas obtidas in vitro}

Uma vez que existem autores que recomendam a utilização de reguladores de crescimento (auxinas) para a indução do enraizamento en Musa e outros que dispensam a sua utilização, realizou-se o Experimento 5 para a determinação dos melhores reguladores de crescimento e concentraçōes adequadas a serem utilizados para o enraizamento de plântulas de bananeira "Maçã". Para tanto, foram usadas 130 plantas, com aproximadamente $3,5 \mathrm{~cm}$ de altura, originadas do cultivo in vitro e que ainda não estavam enraizadas.

os reguladores de crescimento testados foram as auxinas IAA, IBA e NAA, nas concentraçōes de $0 ; 0,1 ; 0,5 ; 1,0$ e 5,0 $\mathrm{mg} / 1$. O delineamento foi inteiramente casualizado e cada tratamento contou com 10 repetições (1 plântula por repetição). As plântulas foram inoculadas individualmente em tubos de ensaio 
contendo $25 \mathrm{ml}$ de meio MS, vitaminas de MW e sem a presença de citocininas, com $3 \%$ sacarose e o pH do meio foi ajustado para 5,7 5,8 e solidificado com $1,5 \mathrm{~g} / 1$ de gel (phytagel - Sigma). Foram a seguir levados para sala com temperatura controlada entre $26-27^{\circ} \mathrm{C}$ e sob 16 horas de $1 u z\left(25 \mathrm{w} / \mathrm{m}^{2}\right)$ e 8 de escuro.

A avaliação foi feita atraves de mediçós do crescimento da parte aérea e sistema radicular, 14 dias após a inoculação. A análise estatistica foi realizada através de análises de variancia e foi utilizado o Teste de Tukey para as médias transformadas segundo $\sqrt{ }\left(\mathrm{x}+\frac{3}{2}\right)$.

3.2. Radiossensitividade de ápices caulinares de bananeira "Maça" (grupo AAB)

Visando-se a utilização de indução de mutação em ápices caulinares para o melhoramento genetico de Musa sp, cultivar Maçã, foram realizados dois experimentos de radiossensitividade de ápices caulinares, ambos partiram de plantas in vitro, contendo parte aérea e sistema radicular bem formados, com aproximadamente $7,0 \mathrm{~cm}$ de altura e $0,7 \mathrm{~cm}$ de largura basal, e que ainda eram mantidas na condição estéril (in vitro).

No primeiro experimento (Experimento 6) foram utilizadas 84 plantas, distribuidas em 6 tratamentos (doses de radiação gama) com 14 repetições (um ápice caulinar por repetição). As plantas, em câmara asséptica, sofreram o corte da parte aérea 2,5 
cm acima do rizoma com o auxilio de pinça e bisturi flambados, retirando-se também as raizes. Foram, então, retiradas as bainhas foliares, até que o explante ficasse com aproximadamente $0,7 \mathrm{~cm}$ de diâmetro basal e $1,0 \mathrm{~cm}$ de altura. A seguir realizou-se um corte longitudinal no explante, dividindo-o em duas partes simetricas, passando este corte pelo centro do meristema apical da planta contido no explante.

Os explantes foram colocados em placas de Petri ( 10 cu de diametro) estéreis, na ausência de meio de cultura, e levados a fonte de $\operatorname{co}^{50}$ do CENA, e colocados no centro, utilizando-se a abertura dos cilindros de $40 \mathrm{~cm}$, foram irradiados com as doses de $0,20,40,60,80$ e $100 \mathrm{~Gy}$, com a taxa de dose de $1140 \mathrm{~Gy} / \mathrm{h}$. Após irradiação foi realizada inoculação em meio de cultura semi-sólido de MS, macro e micronutrientes, vitaminas de MW, suplementado com $5,0 \mathrm{mg} / 1$ de BAP, 3\% sacarose, $\mathrm{pH} 5,7-5,8$ e solidifidado com 6,5 $g / 1$ de ágar.

os explantes foram então levados para sala com temperatura controlada entre $26-27^{\circ} \mathrm{C}$ e sob 16 horas de $14 \mathrm{u}$ (25 $\left.w / m^{2}\right)$ e 8 de escuro.

A avaliação da radiossensitividade foi baseada em contagens quinzenais do número de brotos originados, durante 75 dìas após a irradiação. A análise estatística foi realizada através de análises de variancia e foi utilizado o Teste de Tukey para as medias transformadas segundo $\sqrt{ }\left(x+\frac{1}{2}\right)$. 
Com a finalidade de se confrontar a avaliação da radiossensitividade através de contagem do número de brotos com a avaliação através de pesagem dos explantes em brotação, realizou-se então o Experimento 7. Neste segundo experimento de radiossensitividade o procedimento foi semelhante ao adotado no experimento anterior, excetuando-se que neste caso foram utilizadas 112 plantas em 4 tratamentos, que consistiram nas doses de $0,20,40$ e 60 Gy de radiaçâo gama sob taxa de dose de 837,4 Gy/h, e abertura dos cilindros da fonte de $40 \mathrm{~cm}$. Cada tratamento contou com 28 repetiÇōes ou ápices caulinares, os quais neste caso não foram divididos longitudinalmente. A avaliação se deu através de pesagens semanais dos explantes e dos brotos originados durante 35 dias após irradiação.

A análise estatística foi realizada através de analises de variancia e foi utilizado o Teste de Tukey para as médias transformadas segundo $\sqrt{ }\left(x+\frac{1}{2}\right)$.

\subsection{Isolamento dos setores mutados}

Após ter ocorrido um bom desenvolvimento dos explantes irradiados, com a formação de novos brotos, estes sofreram 3 a 4 repicagens sucessivas, seguindo metodologia adotada por NOVAK et al. (1990). O objetivo destas repicagens foi a obtenção das gerações $M_{1} V_{4}$, isto é, plantas originadas de explantes que sofreram um tratamento mutagênico e que foram subcultivadas por 
4 ciclos vegetativos. Isto teve que ser feito em virtude do quimerismo esperado quando se irradiam estruturas multicelulares (ápice caulinar), como explicado anteriormente.

Estas repicagens consistiram na separação, com o auxílio de pinça e bisturi flambados, dos brotos formados, quando as regióes onde o tecido rizomatoso basal apresentasse escurescimento, segundo KRTKORTAN (indicação pessoal), e re-inoculação em meio de cultura (mesmos componentes descritos no item 3.2. ).

A Erequencia de tempo para a troca de meio foi de 20 - 30 dias entre cada repicagem. En alguns casos, quando se atrasou a troca de meio das brotações ( 30 - 35 dias), iniciou-se processo de enraizamento nas plântulas; neste caso, as repicagens consistiram na retirada do sistema radicular e na divisão destas plântulas em duas partes simétricas, passando-se os cortes pelos centros dos meristemas apicais das mesmas, e re-inoculação em meio de cultura. Isto teve a função de induzir a formação de novos brotos.

Esta fase durou aproximadamente 5 meses, sendo dois destes para a adaptação e brotação inicial dos explantes in vitro, originando assim a primeira geração vegetativa, a qual foi avançada por mais três meses até atingir a quarta e última geração vegetativa. Durante estes procedimentos, buscou-se observar a ocorrência de diferenças na capacidade de micropropagação e diferenças fenotipicas nas plântulas originadas após o uso da radiação gama, para as diferentes doses que permitiram a sobrevivência e propagação dos explantes iniciais irradiados. 


\subsection{Aclimatação das plântulas em solo}

Para a seleção de mutantes resistentes à Fusariose, através de rega com suspensões de esporos do fungo, foi necessária a aclimatação das plantas nicropropagadas em casa de vegetação. Os brotos obtidos do cultivo in vitro, após quatro geraçóes vegetativas foram enraizados, para isto foram inoculados em meio de cultura semi-sólido contendo macro e micronutrientes de MS (como sugerido por LAMEIRA, 1987), vitaminas de MW, na ausência de reguladores de crescimento, $3 \%$ sacarose, $\mathrm{pH} 5,7-5,8$ e solidificados com $6,5 \mathrm{~g} / 1$ de agar. Foram então aclimatados em sala com temperatura controlada entre $26-27^{\circ} \mathrm{C}$ e sob 16 horas de 1 uz $\left(25 \mathrm{~W} / \mathrm{m}^{2}\right)$ e 8 de escuro, permanecendo neste meio por cerca de 30 dias.

Após as plântulas atingirem $6-9 \mathrm{~cm}$, foram levadas para casa de vegetação, onde foram aclimatadas em sacos plásticos de $10 \times 12 \mathrm{~cm}$, contendo mistura autoclavada de terra argilosa, esterco de curral e areia nas proporçós de $1: 1: 1$, respectivamente. As mudas foram colocadas dentro de câmara úmida (cobertura com plástico) com a utilização de nebulizadores, durante 4 dias. Após este período, foram retiradas e mantidas dentro de casa de vegetação.

Durante a fase de desenvolvimento das plantas em casa de vegetação, estas foram avaliadas para possíveis alterações fenotipicas, as que apresentaram alteraçōes significativas, em relação ao padrão normal de plântulas foram separadas das demais. 
Após a maioria das plantas ter atingido o tamanho de 10-15 cm, o que levou de 30 a 40 dias, iniciou-se o processo de inoculação para a seleção de possiveis plantas resistentes à Fusariose.

3.5. Isolawento do $F$. oxysporum f. sp. cubense

- agente causal da Fusariose (Fusarium oxysporum f.sp. cubense) foi obtido a partir de plantas que apresentavam sintomas tipicos da doença em sitio agricola situado em Itapetininga (região de Sorocaba - S.P.). Tais sintomas compreendiam o amarelecimento das folhas das bordos para a nervura central, das folhas mais velhas para as mais novas, e necrose dos tecidos do rizoma e dos vasos de condução de seiva do rizoma e pseudocaule. A partir desta fonte foram inoculadas plantas em casa de vegetação e re-isolado o patógeno quando necessário.

Para o isolamento, rizomas de bananeiras do cultivar "Maçã", infectados com o Fusarium oxysporum f.sp. cubense, foram limpos, retirando-se a terra e as raizes assim como os tecidos necrosados. Estes foram lavados com detergente em água corrente, sendo subdivididos em seguida, em segmentos apresentando aproximadamente $1 \mathrm{~cm}^{3}$ de dimensão, os quais foram imersos em álcool $95^{\circ} \mathrm{GL}$ por 5 minutos para a quebra da tensão superficial e imersos em solução de hipoclorito de $\mathrm{Na}(3 \%)$, diluído (3:1), sob agitação por 15 minutos para a esterilização superficial. 
Em uma câmara de fluxo lâminar foram retirados pequenos pedaços de $0,5 \times 0,5 \mathrm{~cm}$, os quais foram novamente imersos em álcool $95^{\circ} \mathrm{GL}$ por 3 minutos e em solução de hipoclorito (3:1) por 5 minutos, sendo então enxaguados em água destilada autoclavada quatro vezes. Este processo de desinfeç̧ão superficial teve a finalidade de eliminar outros microrganismos que pudessem comprometer o desenvolvimento e a identificação do Fusarium em meio de cultura.

Foi realizada então a inoculação destes pedaços em placas de Petri contendo meio sólido contendo ágar e água. Após 4 a 5 dias foram repicados pequenos segmentos (aproximadamente $2 \mathrm{~mm}$ de diâmetro) deste meio contendo hifas do fungo para placas de Petri contendo o meio de cultura BDA (batata - dextrose - ágar) e incubados sob luz continua em B.O.D., à temperatura de $25^{\circ} \mathrm{C}$.

Com a finalidade de se conhecer o melhor tempo em cultivo para originar maior número de esporos para inoculação, foi instalado o Experimento 8 que constou de 60 placas contendo BDA, nas quais foram inoculadas o Fusarium e incubados sob luz contínua, à temperatura de $25^{\circ} \mathrm{C}$. As avaliações foram feitas aos $7,15,25,38$ e 60 dias e foram avaliadas 12 placas por tratamento, através de contagem dos esporos obtidos em cada espaço de tempo.

Para cada placa de Petri (10 cm de diâmetro) contendo BDA (batata-ágar-dextrose) com hifas e esporos de Fusarium oxysporum f.sp. cubense, adicionou-se $10 \mathrm{ml}$ de água destilada estéril (autoclavada) e realizou-se a seguir a raspagem da camada superficial de maneira a desprenderem-se os esporos. Esta suspensão 
então foi avaliada, com auxílio de microscópio e câmara de Neubauer $\left(0,1 \mathrm{~mm}\right.$ de profundidade - com 100 campos de $0,0025 \mathrm{~mm}^{2}$ subdivididos por 4 campos de $0,0625 \mathrm{~mm}^{2}$ ) através de contagem do número de esporos/ml. O tempo de cultivo que apresentasse maior produção de esporos seria o mais adequado para o trabalho de inoculação das plantas jovens e selecão de possiveis mutantes resistentes à Fusariose.

A análise estatistica foi realizada através de analises de variância e foi utilizado o Teste de Tukey para as médias transformadas segundo $\sqrt{ }\left(x+\frac{1}{2}\right)$.

\subsection{Inoculação em casa de vegetação}

As plântulas originadas do cultivo in vitro, de ápices caulinares irradiados (doses de $0,20,40,60$ Gy, como descrito no item 3.2.$)$ e subcultivadas por quatro gerações vegetativas $\left(M_{1} V_{4}\right.$, para se ampliar os possiveis setores mutados, como descrito no item 3.3.), foram enraizadas e transferidas para solo autoclavado em casa de vegetação (item 3.4.). Estes procedimentos, ilustrados pela Figura 2 , foram executados em 8 meses aproximadamente, quando as plantas já possuiam cerca $10-15 \mathrm{~cm}$ de altura (comprimento do pseudocaule). Ao todo foram 2765 plântulas obtidas através deste procedimento descrito.

Para a execução da inoculação em casa de vegetação (Experimento 9) foi seguida metodologia estabelecida por MENDES et 
a1. (1989), os quais determinaram a utilização de rega com suspensão com $5 \times 10^{4}$ esporos/ml, adicionando-se $50 \mathrm{ml}$ desta suspensão por planta medindo aproximadamente $10-15 \mathrm{~cm}$ de altura e aclimatada em solo autoclavado.

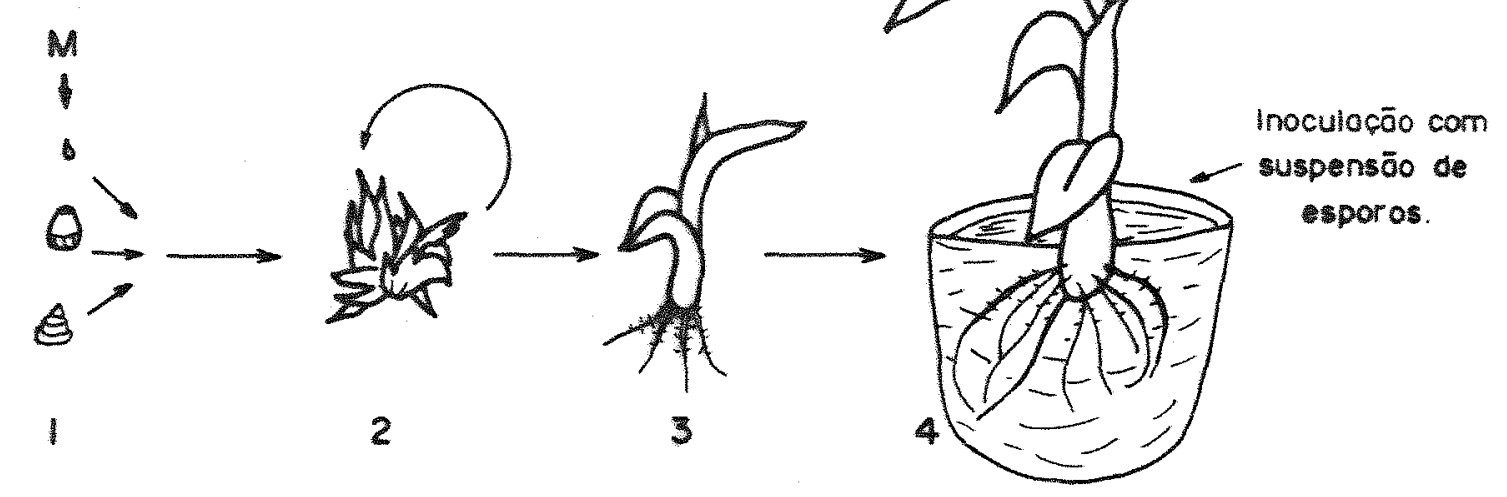

Figura 2 - Desenho ilustrativo do processo de irradiação (M) de ápices caulinares (1) e sua micropropagação (2) por diversas gerações vegetativas, obtendo plântulas $M_{0} V_{4} e$ $\mathrm{M}_{3} \mathrm{~V}_{4}$ (3) as quais são inoculadas em casa de vegetação (4) com suspensão de esporos do Fusarium oxysporum f.sp. cubense

Em placas de Petri ( $10 \mathrm{~cm}$ de diâmetro) contendo BDA (batata-ágar-dextrose) e recobertas com hifas e esporos de Fusarium oxysporum f.sp. cubense, colocou-se $10 \mathrm{ml}$ de água destilada e realizou-se a seguir a raspagem da camada superficial de maneira a 
desprenderem-se os esporos. Esta suspensão então foi diluida em água destilada até que apresentou concentração próxima à 5 x $10^{4}$ esporos/ml. Tal concentração foi determinada com auxilio de microscópio e câmara de Neubauer $(0,1 \mathrm{~mm}$ de profundidade - com 100 campos de 0,0025 $\mathrm{mm}^{2}$ subdivididos por 4 campos de $0,0625 \mathrm{~mm}^{2}$ )

A inoculação fol feita utilizando-se $50 \mathrm{ml}$ da suspensão para cada planta de bananeira "Maçã". Estas plantas estavam bem aclimatadas em solo autoclavado, com cerca de $15 \mathrm{~cm}$ de pseudocaule e bor enraizamento. Ao redor do pseudocaule, no colo da planta, foi feita com o auxilio de uma espatula, uma escarificação de maneira a provocar uma descompactação superficial do solo. provocando simultaneamente leve ferimento das raizes superficiais, regando-se as mudas à seguir. As plantas sobreviventes após a primeira inoculação foram mantidas e re-inoculadas novamente, de modo a se eliminar possiveis escapes.

A avaliação dos sintomas fol realizada através da observação visual das alterações externas e internas das plantas jovens inoculadas. Foram considerados com sintomas tipicos as plantas que apresentaram rachaduras no pseudocaule, acompanhadas de necrosamento dos tecidos, amarelecimento das folhas mais velhas para as mais novas, necrosamento e morte ou que apresentaram brotações posteriores lateralmente aos pseudocaules pré-existentes.

Para avaliação foi feita contagem simples das plantas que apresentaram sintomas após inoculação com o fungo, sendo anotadas também as que morreram $e$ as que apresentaram recuperação, podendo ser novamente inoculadas. 


\subsection{Avaliação da variabilidade fenotipica}

os ápices caulinares de Musa, quando cultivados in vitro por diversas geraçōes vegetativas, podem apresentar variações somaclonais, as quais podem ser reversiveis ou não. o presente trabalho utilizou-se de metodologias que envolven a micropropagaça de ápices caulinares do cultivar Maçã (grupo AAB) por 4 geraçóes vegetativas e a utilização de mutagênico físico (radiação gama) visando indução de nutações; deste modo, buscou-se quantificar a variabilidade gerada in vitro. Observou-se o material durante a micropropagação e durante aclimatação e estabelecimento em casa de vegetação.

Como os trabalhos com indução de mutações envolveram a utilização de plantas irradiadas nas diversas doses citadas e plantas testemunhas, não irradiadas, observou-se em laboratório e principalmente, em casa de vegetação o aparecimento das alterações fenotipicas nestas plantas jovens, que pudessem denotar alterações de ordem genética provocadas pelo uso da radiação gama (plantas originadas de ápices caulinares irradiados), ou provocadas pela variação somaclonal (plantas testemunhas).

o Experimento 10 teve como finalidade a quantificação, em casa de vegetação, da variabilidade fenotípica, em 2070 plântulas obtidas, as quais foram avaliadas através de caracteres fenotipicos como coloração, tamanho, formato e angulação das folhas, tamanho e desenvolvimento das plantas, e tamanho e coloração dos peciolos e do pseudocaule. Uma vez quantificadas 
estas alterações, foram calculadas as frequências dos tipos de variantes fenotipicos obtidos, a partir das plantas irradiadas (possiveis mutantes induzidos) e não irradiadas (variantes somaclonais).

Da irradiação até a avaliação em casa de vegetação passaram-se 8 meses, aproximadamente, a avaliação foi visual, através de contagem dos variantes e os dados foram apresentados em percentuais de variantes fenotipicos obtidos.

\subsection{Indução da embriogênese somática}

Os estudos visando a embriogênese somática em Musa, realizados no presente trabalho, basearam-se em metodologia descrita por NOVAK et al (1989). A indução da embriogênese somática foi executada em três diferentes etapas. Na primeira realizou-se a indução de estruturas embriogênicas (estruturas globulares e calos) em tecidos do rizoma e pseudocaule de plantulas, cultivadas in vitro, para os cultivares Maçã, Nanicão e o clone GN-60. Na segunda etapa, realizou-se o cultivo destas estruturas, em meio liquido sob elevada agitação, para a formação e desenvolvimento dos embrióides e na terceira e última etapa foram colocados os embrióides em meio de dupla fase, uma sólida contendo anti-oxidante e uma líquida contendo Zeatina para indução da germinação e obtenção de plântulas, a partir dos embriões somáticos. 
3.8.1. Obtenção das estruturas embriogênicas

Para obtenção da embriogênese somática em tecidos do rizoma e pseudocaule de Musa, para os clones Maçã, Nanicão e GN-60, foi necessária a realização de experimento para avaliação do regulador de crescimento a ser utilizado (Dicamba) na induça de formação das estruturas embriogênicas, e as concentrações mais adequadas do mesmo, observando possiveis diferenças de resposta entre os três diferentes cultivares utilizados (Experimento 11).

Além disso foram avaliados os níveis de oxidação dos explantes, correlacionando estes dados com as concentraçōes do regulador de crescimento e as dimensóes do explante. Foi ainda verificado quais os melhores segmentos de rizoma e/ou pseudocaule, obtidos das plântulas, que melhor responderam à indução da embriogênese.

A partir de 65 plântulas de bananeira "Maçá", obtidas in vitro, com aproximadamente $9,0 \mathrm{~cm}$ de altura e $1,5 \mathrm{~cm}$ de diâmetro basal, foram retirados ápices caulinares nas dimensões aproximadas de $1,0 \mathrm{~cm}$ de diametro basal e 1,5 cm de comprimento, dos quais foram retiradas as bainhas foliares (ápice caulinar $n^{2} 3$ da Figura 1), em câmara de fluxo laminar. Estes explantes foram então inoculados em meio líquido de MS, macro e micronutrientes, vitaminas de MW, suplementado com $5,0 \mathrm{mg} / 1$ de BAP, 3\% sacarose, $\mathrm{pH}$ $5,7-5,8$

os explantes foram então levados para sala com temperatura controlada entre $26-27^{\circ} \mathrm{C}$ e sob 16 horas de $14 z$ ( 25 
$\left.W / \mathrm{m}^{2}\right)$ e 8 de escuro, sobre agitador rotativo (65 $\left.\mathrm{rpm}\right)$, realizandose troca de meio a cada 15 dias. Após 2 meses o número de brotos foi triplicado, estes então foram utilizados com a finalidade de obtenção de pró-embrióides após atingirem $5 \mathrm{~cm}$ de altura e aproximadamente $0,8 \mathrm{~cm}$ de espessura, estando ainda livres de enraizamento.

Foram utilizados 192 brotos, os quais foram recortados, sob câmara asséptica com auxilio de um bisturi e pinças devidamente flambados, a partir da base para o ápice em secções transversais com $6-8 \mathrm{~mm}$ de diâmetro e aproximadamente $2 \mathrm{~mm}$ de espessura, como ilustrado na Figura 3.

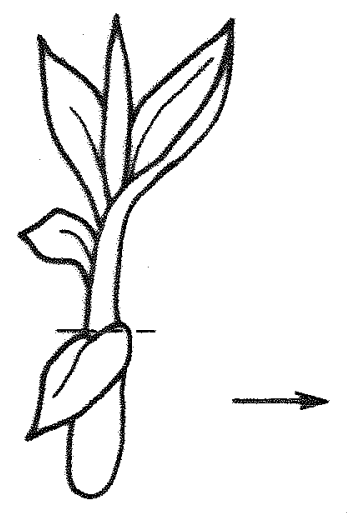

0

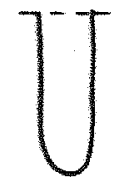

b

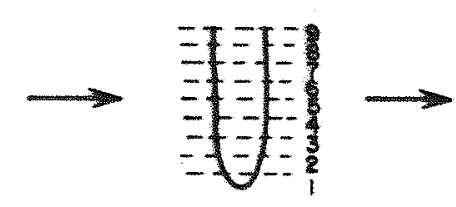

C
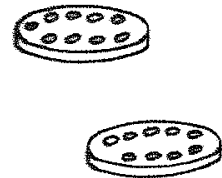

d

Figura 3 - Desenho ilustrativo do processo de indução da embriogê nese somática em Musa. A partir de una plântula obtida in vitro (a) é extraído segmento contendo rizoma e pseudocaule (b), o qual é seccionado transversalmente em segmentos (c) de aproximadamente $2 \mathrm{~mm}$ de diâmetro (nume rados de 1 a 9) e plaqueados em meio com Dicamba (d). 
Tais seç̧ões foram realizadas até aproximadamente 6 mm acima do ápice meristemático, após o que foram inoculadas em placas de Petri ( $10 \mathrm{~cm}$ de diametro) contendo meio semi sólido de SCHENK \& HILDEBRANDT (1972), macro e micronutrientes, e as vitaminas de staba, em concentrações modificadas por NovAK et al. (1989), composta de Tiamina $(2,0 \mathrm{mg} / 1)$, Ac. Nicotinico $(2,0 \mathrm{mg} / 1)$, piridoxina $(2,0 \mathrm{mg} / 1)$, Pantotenato de $\mathrm{Ca}(1,0 \mathrm{mg} / 1)$, P-amino benzóico $(0,5 \mathrm{mg} / 1)$, Cianocobalina $(1,5 \mathrm{mg} / 1)$, Riboflavina $(0,5$ $\mathrm{mg} / 1)$, Cloreto de colina $(1,0 \mathrm{mg} / 1)$, Acido fólico $(0,5 \mathrm{mg} / 1)$ e biotina $(1,0 \mathrm{mg} / 1)$, suplementado com Inositol 100,0 mg/l, Cisteína $40,0 \mathrm{mg} / 1$, Dicamba $(0 ; 2,00 ; 3,35$ e 6,63 mg/1), Sacarose $2 \%$, pH $5,7-5,8$, Ágar $7,0 \mathrm{~g} / 1$.

o experimento possuiu delineamento inteiramente casualizado, constou dos 3 clones de bananeira (Maçã, Nanicão e $\mathrm{GN}-60$ ) tratados com as concentrações $0: 2,00 ; 3,35$ e $6,63 \mathrm{mg} / 1$ do regulador de crescimento (Dicamba), com 16 repetiçóes (placas de Petri) por tratamento, sendo que cada placa de Petri conteve os explantes obtidos de uma plântula.

Após inoculação estas placas foram devidamente vedadas e colocadas em câmara escura (B.O.D.) à temperatura constante de $26,5^{\circ} \mathrm{C}$.

A avaliação da melhor concentração de Dicamba, foi realizada em percentual médio de explantes que responderam ao tratamento com formação de estruturas embriogênicas. os dados de oxidação foram avaliados em percentual médio de explantes que apresentaram escurescimento dos explantes. As análises estatisticas 
foram realizadas através de análises de variancia e foi utilizado - Teste de Tukey para os percentuais transformados segundo arco seno $\sqrt{ } \mathrm{x} / 100$.

A posição adequada da planta que originou explantes mais responsivos foi avaliada através de numeração do rizoma para - pseudocaule de 1 a 9 (como ilustra a Figura 3), sendo que os números 3,4 e 5 corresponderam à região que envolve o meristema apical, estando a posição três logo abaixo e a posição 5 logo acima do tecido meristemático apical. Foi então observada a resposta dos explantes, e aqueles que melhor respondiam ao tratamento, receberam notas que corresponderam ao seu número inicial (de 1 a 9).

A análise estatística foi realizada através de análises de variância e foi utilizado o Teste de Tukey para as médias transformadas segundo $\sqrt{ }\left(\mathrm{x}+\frac{1}{2}\right)$.

Paralelamente foi montado experimento de maneira semelhante a este anterior, fixando-se a concentração de Dicamba em $6.63 \mathrm{mg} / 1$, com a finalidade de se estudar o efeito da concentração de sacarose na formação de estruturas embriogênicas (Experimento 12).

Para tanto foram utilizadas duas concentrações de sacarose, a primeira com $2 \%$ de sacarose, a segunda com $4 \%$ de sacarose, cada tratamento contou com 14 repetições, sendo que cada repetição constou de uma planta, cujos tecidos do rizoma e 
pseudocaule foram subdivididos transversalmente em aproximadamente 6 segmentos (explantes)/plântula.

A leitura dos dados foi realizada em percentual médio de explantes que formaram calos e percentual medio de explantes que formaram estruturas globulares.

\subsubsection{Obtenção desenvolvi dos embrióldes}

Após a formação dos emorióides a partir das estruturas embriogênicas (calos e estruturas globulares), estes foram então transferidos para Erlenmeyers ( $250 \mathrm{ml}$ ) contendo $50 \mathrm{ml}$ de meio Ifquido de SH, macro e micronutrientes, vitaminas de Staba modificadas, suplementado com Inositol 100,0 mg/1, Cisteina 40,0 $\mathrm{mg} / 1$, Dicamba $3,5-4,42 \mathrm{mg} / 1$, Sacarose $3 \%, \mathrm{pH} 5,7-5,8$.

Estes recipientes ficaram então sob agitação (80 120 rotaçōes por minuto), sob 1 uz $38 \mathrm{~W} / \mathrm{m}^{2}$, realizando-se as trocas de meio semanalmente e após um período de 2 meses aproximadamente, foram obtidas suspensóes celulares, a partir dos calos ou estruturas globulares, e suspensões contendo estruturas originadas das estruturas globulares (embrióides).

Após a obtenção das suspensões celulares e de embrióides, ambas foram transferidas para meio liquido, com a finalidade de se retirar os residuos do regulador de crescimento 
(Dicamba) utilizado no estágio de formação e desenvolvimento dos mesmos. Este meio 11quido, onde os embrioides ficaram de $24-48$ horas sob agitação constante de $70 \mathrm{rpm}$ sob $1 \mathrm{uz} 38 \mathrm{~W} / \mathrm{m}^{2}$, possuiu macro e micronutrientes de SH, vitaminas modificadas de staba, e foi suplementado com cisteína $40,0 \mathrm{mg} / 1$, inositol $100,0 \mathrm{mg} / 1$, sacarose 28, pH $5,7-5,8$.

Após este perído estes embrioides foram inoculados em meio semelhante ao acima citado, suplementado com $1,5 \mathrm{mg} / 1$ de Zeatina, para desenvolvimento dos embrióides, as quais após desenvolvimento, após 2 meses aproximadamente, apresentaram dimensões em torno de 1 - 2 mm de diâmetro.

Para germinação dos embrióides, foi utilizado meio contendo duas fases, uma sólida e a outra liquida, em volume de 50 ml cada, a fase sólida foi autoclavada e constou de sH macro e micronutrientes e vitaminas modificadas de staba, suplementado com cisteina $40,0 \mathrm{mg} / 1$, inositol $100,0 \mathrm{mg} / 1$, sacarose $2 \%$, carvão ativado $1,5 \mathrm{~g} / 1$, ágar $7,0 \mathrm{~g} / 1, \mathrm{pH} 5,7-5,8$.

A fase liquida foi filtrada e conteve SH macro e micronutrientes e vitaminas modificadas de Staba, suplementado com cisteina $40,0 \mathrm{mg} / 1$, inositol $100,0 \mathrm{mg} / 1$, Zeatina $2,2 \mathrm{mg} / 1$, sacarose $2 \%, \mathrm{pH} 5,7-5,8$.

Após a solidificação do meio sólido adicionou-se o meio Ifquido na parte superior, onde então se adicionou os embrióides desenvolvidos que ficaram sob agitação constante de 65 rpm sob luz $38 \mathrm{~W} / \mathrm{m}^{2}$ para germinação. 
Como observou-se que a resposta entre cultivares foi distinta, e mesmo dentro de cada cultivar a variação foi pronunciada, realizou-se experimento para se quantificar tais variações (Experimento 13).

o delineamento foi inteiramente casualizado e cada tratamento contou com 15 frascos com 15 embribides. A leitura dos dados foi realizada em percentual médio de embrióides que formaram raizes, percentual médio de embrióides que não formaram raízes, e percentual de oxidação dos embrióides. A análise estatistica foi realizada através de análises de variância e foi utilizado o Teste de Tukey para os percentuais transformados segundo arco seno $\sqrt{ } x / 100 \cdot$

\subsection{Cultivo de células e obtenção de protoplastos}

Através das estruturas embriogênicas obtidas através do procedimento descrito no item 3.8.1. foi realizada a produção de suspensōes celulares. Com o auxilio de bisturi e pinça flambados retirou-se as estruturas embriogênicas dos explantes iniciais, sendo parte delas calos translúcidos, parte calos opacos e parte estruturas globulares.

Estes três tipos de formaçōes foram então transferidos para Erlenmeyers (250 $\mathrm{ml}$ ) contendo $50 \mathrm{ml}$ de meio líquido de $\mathrm{SH}$, macro e micronutrientes, vitaminas modificadas de staba, suplemen- 
tado com Inositol $100,0 \mathrm{mg} / 1$, Cisteína $40,0 \mathrm{mg} / 1$, Dicamba $3,5-$ $4,42 \mathrm{mg} / 1$, Sacarose $3 \%, \mathrm{pH} 5,7-5,8$.

Estes recipientes ficaram então sob agitação (80 120 rotações por minuto), sob luz $38 \mathrm{w} / \mathrm{m}^{2}$, realizou-se as trocas de meio semanalmente. Sob estas condições o cultivo dos calos mais opacos e das estruturas globulares, permitiran a formação de suspensōes celulares.

Foram então obtidas suspensões celulares concentradas, as quais foram utilizadas para isolamento de protoplastos. Foram utilizadas soluções de enzima indicadas por KRIKORIAN et al. (1988) contendo celulase a 1\%, macerase a $0,5 \%, \mathrm{CaCl}_{2}$ a $0,05 \%, \mathrm{MES}$ (3mM). Manitol + Sorbitol $(0,4 \mathrm{M})$ e $\mathrm{O} \mathrm{pH}$ ajustado para 5,7 .

Foram também utilizadas soluçōes de enzima indicadas por NOVAK et al. (1992), contendo celulase a $3 \%$, macerase a $1 \%$, pectinase a $1 \%, \mathrm{CaCl}_{2}(6 \mathrm{mM}), \mathrm{NaH}_{2} \mathrm{PO}_{4}(0,7 \mathrm{mM})$, Manitol + Sorbitol $(0,4 \mathrm{M})$, e $\mathrm{pH}$ ajustado para 5,7 .

Com a finalidade de se comparar estes dois protocolos distintos, realizou-se o Experimento 14. A cada solução de enzima foram adicionadas aliquotas da suspensão celular, na proporção de $2 \mathrm{ml}$ de solução enzimática para $2 \mathrm{ml}$ de suspensão celular em placas de petri ( $4 \mathrm{~cm}$ de diametro). As placas de Petri foram então mantidas no escuro, para se evitar a degradação das enzimas pela luz, sob agitador (45 rpm). O material foi avaliado a cada 2 horas em microscópio invertido, para se escolher o tempo mais adequado para isolamento de protoplastos de bananeira "Maçã", nestas condiçōes. 
Os protoplastos foram purificados em centrifuga durante 4 minutos a 700 rpm para 1 impeza da enzima e 6 minutos com $5 \mathrm{ml}$ de sacarose $25 \%$, CPW $(0,7 \mathrm{M})$ a $300 \mathrm{rpm}$, e plaqueados em Erlenmeyers $(250 \mathrm{ml})$ contendo $50 \mathrm{ml}$ de meio 11 quido de $\mathrm{SH}$, macro e micronutrientes, vitaminas modificadas de staba, suplementado com Tiamina $5,0 \mathrm{mg} / 1$, Ac. Nicotinico $5,0 \mathrm{mg} / 1$, Piridoxina $0,5 \mathrm{mg} / 1$, Inositol 100,0 mg/1, Cisteina 40,0 mg/1, Dicamba 3,5-4,42 mg/1, Sacarose $3 \%, \mathrm{pH} 5,7-5,8$. 


\section{RESULTADOS E DISCUSSÃO}

4.1. Obtenção e cultivo de eriste政as iniciais de plantas do canpo, obtidos a partir de apices vegetativos ou florais

Do total de ápices caulinares iniciais de bananeira dos cultivares Maçã e Nanicão inoculados, assim como dos ápices meristemáticos obtidos de inflorescências do cultivar Nanica, aproximadamente $16 \%$ apresentaram contaminação com bactéria ou por infestação (contaminação externa) ou infecção (interna). A possibilidade da existência de contaminantes internos, em explantes, que venham a se manifestar durante o cultivo in vitro, também foi levantada por outros autores, entre eles LOPES (1989). No presente trabalho, durante as inoculacões posteriores, no entanto, - percentual foi reduzido de $16 \%$ para 5\%. Como observado por CRONAUER \& KRIKORIAN (1984b) e (CRONAUER-MITRA \& KRIKORIAN, 1986), a desinfeç̧ão através de solução de hipoclorito de sódio a $0,5 \%$, praticamente eliminou a contaminação externa, trazida pelos explantes do campo.

Notou-se também a ocorrência de escurescimento dos tecidos devido a oxidações. Observou-se que trabalhando com explantes maiores a possibilidade de contaminação se elevou, porém os problemas com oxidação diminuiram, DE GUZMAN et al. (1976) e 
WONG (1986) fizeram uso de explantes maiores, com aproximadamente $1 \mathrm{~cm}^{3}$, e não indicaram inconvenientes com a assepsia.

BERG \& BUSTAMANTE (1974), GUPTA (1986) e KRIKORIAN \& CRONAUER (1984), recomendaram a utilização de explantes menores ( 1 - $3 \mathrm{~mm}$ ) para maior garantia da sanidade do material, deste modo para o presente trabalho optou-se por iniciar o cultivo a partir de plantas do campo com tecidos meristemáticos apicais com 2 mm de diâmetro, e para trabalhos visando a indução de mutações trabalhouse com ápices caulinares de plantas obtidas in vitro, das quais foram retirados ápices caulinares medindo aproximadamente $1 \mathrm{~cm}^{3}$.

os ápices caulinares inoculados, que a principio possuíam a coloração creme, adquiriram a coloração verde após uma semana, CRONAUER \& KRIKORIAN (1984b) também observaram estas alterações, porém no presente trabalho, além da coloração esverdeada os explantes apresentaram leve escurescimento devido a oxidação superficial dos mesmos, a qual, não chegou a prejudicar o seu desenvolvimento mas ocorreu para todos os cultivares utilizados.

Durante os primeiros vinte dias ocorreu entumecimento do explante, que cresceram diametralmente. Após 25-35 dias de cultivo iniciaram as brotações que atingiram em média 5-6 brotos por ápice caulinar em 45 dias de cultivo. Seguindo recomendação de KRIKORIAN \& CRONAUER (1984) observou-se que a subdivisão longitudinal dos explantes pelo centro do ápice estimulou maior brotação, uma vez que foi retirada a dominância apical. 
Foram produzidas aproximadamente $3 \mathrm{mil}$ plantas de bananeira in vitro, durante a realização deste trabalho, dos cultivares Maçã, Nanicão e do clone GN-60.

\subsection{Capacidade de brotação de ápices caulinares extraidos de diferentes 政aneiras}

Após um mês em cultivo, avaliou-se a capacidade de brotamento dos 5 tipos básicos de explantes adotados (ilustrados na Figura 1). A Tabela 1 e 0 APENDICE 9 apresentam os resultados obtidos com o Experimento 1, onde se encontram os números médios de brotos obtidos através dos diferentes ápices caulinares de bananeira "Maçã" (Grupo AAB) utilizados, cultivados in vitro em meio Iíquido.

Os explantes apresentaram diferenças visuais quanto à capacidade de brotação. Em alguns casos, houve tendência para a formação de plântulas únicas, sem brotações laterais, isto ocorreu em alguns explantes pertencentes ao tipo 2 .

o tratamento que diferiu estatisticamente foi o número 3, isto é, os ápices caulinares que sofreram a retirada das bainhas foliares, os quais apresentaram, em média 3,96 brotos. Os explantes com bainhas mas que sofreram corte longitudinais (1) tiveram a dominância apical diminuida e tambem permitiram maior contato das gemas com o meio de cultura, além de melhor luminosida- 
de, apresentando uma tendência para maior brotação em relação aos tratamentos 2,4 e 5 , com a média de 1,93 brotos.

Já com relação aos ápices caulinares com bainhas (2) comparados aos sem bainha (3), provavelmente a diferença nas médias de brotação deveu-se à quebra de dormência das gemas laterais, no último caso, devido à maior exposição das mesmas à luz e ao contato destas gemas com o meio de cultivo.

Tabela 1. Número medio* de brotos obtidos através de cinco tipos diferentes de ápices caulinares de bananeira "Maçã" (Grupo $A A B$ ) cultivados in vitro em meio Iiquido**.

TIPOS DE ÁPICES CAULINARES \#
NÚMERO

DE REPETIÇÕES
NÚMERO MÉDIO

DE BROTOS

$\begin{array}{lllll}1 & 15 & 1,93 & \mathrm{~b} \\ 2 & 15 & 1,67 & \mathrm{~b} \\ 3 & 15 & 3,96 \mathrm{a} & \\ 4 & 15 & 1,50 & \mathrm{~b} \\ 5 & 15 & 1,31 & \mathrm{~b}\end{array}$

* As médias seguidas por letras distintas diferem entre si, pelo Teste de Tukey, ao nivel de significância de 5\% - (CV. 14,09 \%).

* A avaliação foi feita 30 dias após inoculação.

\# 1. Ápice caulinar com $0,7 \mathrm{~cm}$ de diâmetro basal por $1 \mathrm{~cm}$ de comprimento, contendo o meristema apical mais gemas laterais sem a remoção das bainhas foliares e que sofreram dois cortes perpendiculares longitudinalmente até a altura do meristema.

2. Ápice caulinar com $0,7 \mathrm{~cm}$ de diâmetro basal por $1 \mathrm{~cm}$ de comprimento, contendo o meristema apical mais gemas laterais sem a remoção das bainhas foliares. 
3. Ápice caulinar com $0,7 \mathrm{~cm}$ de diametro basal por $1 \mathrm{~cm}$ de comprimento que sofreu remoção das bainhas foliares, contendo no entanto, o meristema apical mais as gemas laterais.

4. Ápice caulinar com $0,7 \mathrm{~cm}$ de diâmetro basal por $1 \mathrm{~cm}$ de altura, contendo apenas as gemas laterais, uma vez que a que determinava a dominância apical foi removida.

5. Ápice caulinar com $0,1-0,2 \mathrm{~cm}$ de diâmetro, compreendendo a região meristemática contendo 2 - 3 primórdios foliares.

Os explantes compostos apenas de gemas laterais, representados na Figura 1 pelo número 4, apresentaram tendência para média levemente superior aos explantes contendo apenas o meristema (5). Estes últimos, no entanto, apresentaram tendência para uma média mais baixa $(1,31$ brotos). Isto provavelmente porque embora sejam os meristemas que determinam a maior capacidade de brotação e regeneração nos casos de micropropagação, quando este é isolado sofre um maior choque ao ser exposto a um ambiente estranho (1uz, meio de cultura, oxidações, etc), diverso da sua condição natural sob a proteção de primórdios foliares, bainhas e rizoma. Outra possibilidade seria com relação às reservas nutricionais fornecidas pelo rizoma ao meristema apical e que neste caso são diminuídas.

Assim como relatado por DE GUZMAN et al. (1976), observou-se no presente trabalho que a realização de incisões no ápice meristemático eleva o número de brotos, devido à quebra da dominância do ápice caulinar, evitando a recuperação de uma única planta, como ocorreu em alguns explantes do tipo 2 . 
NOVAK et al. (1987) utilizaram explantes que correspondem ao tipo 5 com a finalidade de indução de mutações. No presente trabalho, este explante apresentou tendência para menor media inicial de brotação. Porém este tipo de explante, quando originado diretamente de plantas do campo, minimiza a possibilidade de presença de vírus e outros patógenos segundo GUPTA (1986). KRIKORIAN CRONAUER (1984) e CRONAUER-MITRA \& KRIKORIAN (1986). BROERTJES \& VAN HARTEN (1988) indicaram que gemas adventicias são formadas por poucas células, e portanto indicadas para indução de mutação. Uma vez que BANERJEE et al. (1986) e NOVAK et al. (1987) afirmam que a partir da base dos ápices caulinares de bananeira, são originadas gemas adventicias, então a utilização de ápices maiores que o tipo 5, com maior número de gemas (apical e laterais) forneceria uma maior quantidade de gemas adventicias, e ampliaria a possibilidade de obtenção de mutantes sólidos através da indução de mutações.

Para efeito de indução de mutação e de pesquisa com Musa in vitro, o presente trabalho sugere a utilização de ápices caulinares do tipo 3, para uma maior produção de brotos, porém, os ápices caulinares sem bainha requerem maior trabalho para seu isolamento, que os explantes tipo 1. Para fins de micropropagação deve-se utilizar o tipo 1, que após o número 3 tendeu a uma maior produção de brotos, onde através de cortes longitudinais, atingindo - meristema apical, a capacidade de brotação poderá ser ampliada devido a eliminação da dominância apical. 
4.1.2. Comparação de meio 11quido com e sem agitação con aio sei-sólido

Vários autores, assim como MURASHIGE (1974) recomendam cuidado na escolna do estado físico do meio de cultura, uma vez que a taxa e o padrão de crescimento e morfogênese podem ser afetados. Com a finalidade de se testar a eficiencia do meio de cultura semi-sólido e Iíquido com e sem agitaf̧ão para o cultivo de ápices caulinares em bananeira foi realizado o Experimento 2 .

Na Tabela 2 e no APENDICE 10 estão representadas as médias de brotos obtidas a partir do cultivo in vitro de ápices caulinares do cultivar Maçã em meio semi-sólido, líquido com agitação e líquido sem agitação durante 20 dias.

Tabela 2. Número médio* de brotos obtidos por ápices caulinares de bananeira "Maçã" cultivados in vitro em meio semisólido e Iiquido com e sem agitação**

MEIO

MEDIAS

$\begin{array}{lcc}\text { SEMI-SÓLIDO } & 1,20 \text { a } \\ \text { LIQUIDO COM AGITAÇÃO } & 1,56 \text { a } \\ \text { LIQUIDO SEM AGITAÇÃO } & 0,49 & \mathrm{~b}\end{array}$

* Médias seguidas de letras iguais não diferem significativamente entre si pelo Teste de Tukey - 5\% (CV. 33,94\%).

* A avaliação foi feita 20 dias após a inoculação.

- meio Iiquido com agitação e o meio semi-sólido foram os tratamentos que apresentaram maiores médias $(1,56$ e 1,20 
brotos, respectivamente) sendo que o meio liquido sem agitação induziu baixa brotação $(0,49$ brotos $)$.

Neste último caso a falta de oxigenação do meio IÍquido sem agitação deve ter provocado a redução na capacidade de brotação dos explantes, tal suposição concorda com MURASHIGE (1974) quando afirma que os meios de cultura liquidos estacionários permitem que os explantes afundem nos recipientes, onde a difusão de gases é reduzida.

o meio liquido apresentou média ligeiramente superior ao meio semi-sólido, tal tendência já havia sido observada por CRONAUER \& KRIKORIAN (1984b), porém, o meio Iíquido possue o inconveniente de ser mais susceptivel às contaminações durante a manipulação, além do fato de não permitir uma boa sustentação para os explantes. NOVAK et al. (1990) cultivaram ápices caulinares em meio 1 iquido, visando realização de ensaio de radiossensitividade em 7 clones de Musa, deste modo puderam ter uma avaliação mais rápida dos efeitos da radiação, porém estes ensaios exigem muita manipulação do material e a utilização de meio líquido ter que ser realizada com extremo cuidado para não haver perda de material por contaminação.

Recomenda-se a utilização do meio líquido para o cultivo de ápices caulinares muito pequenos (Figura 1 - tipo 5), os quais sofrem mais com a dessecação, e inicialmente, não necessitam ser sustentados em posição fixa, o que é mais recomendável para plantulas com parte aérea e sistema radicular definidos. 
Deve-se evitar a utilização do meio lfquido sem agitação, uma vez que, como sugerem os dados da Tabela 2 e outros autores, como MURASHIGE (1974) e OZIAS-AKINS \& VASIL (1985) a oxigenação é fator importante para uma boa taxa de brotação. Outro fato observado é que plantas originadas do cultivo de ápices caulinares em meio Iíquido foram mais sensiveis ao transplante para - solo, talvez devido aos tecidos serem mais tenros. o problema foi solucionado com a transferência das plântulas para meio semi-sólido durante a fase de enraizamento.

Como não houve diferença significativa entre os meios semi-sólido e líquido para o cultivo de ápices caulinares, sugere-se a utilização dos semi-solidos, pois apresentam maior facilidade de manuseio, menor risco de contaminação e dispensam a utilização de agitadores.

\subsubsection{Influência do BAP na brotação de ápices caulinares}

Devido a necessidade de se conhecer as melhores concentrações de BAP para a brotação, in vitro, de ápices caulinares do cultivar Maçã, foram realizados os Experimentos 3 e 4.

No Experimento 3 foram testadas as concentrações de $0 ; 2,5 ; 5,0$ e $7,5 \mathrm{mg} / 1$ de BAP. A Tabela 3 mostra a média de brotos obtida por ápice caulinar de bananeira "Maçã" cultivado in vitro sob as concentrações de BAP citadas. 
Assim como sugerido por WONG (1986) o BAP permitiu - brotamento dos ápices caulinares em um número considerado satisfatório de acordo com os objetivos desta pesquisa, dispensando a combinação deste com outro regulador de crescimento. As análises estatisticas para as médias de brotos produzidos sob as diferentes concentraçóes de BAP mostraram diferenças estatisticas apenas para - controle $(0 \mathrm{mg} / 1)$ que praticamente não produziu brotaçóes $(0,54$ brotos por ápice caulinar, em média). A concentração de 5,0 mg/1 apresentou tendência para maior media de brotos $(6,28)$, enquanto que a concentração de $2,5 \mathrm{mg} / 1$ produziu, em média, 4,93 brotos por explante e a concentração de 7,5 produziu 4,55 brotos após 40 dias.

Tabela 3. Média de brotos* obtidos por ápice caulinar de bananeira "Maçã" (Grupo AAB) cultivado in vitro sob diversas concentrações de BAP **.

CONCENTRAÇÃO DE BAP $(\mathrm{mg} / 1)$
NÚMERO MÉDIO

DE BROTOS

$\begin{array}{lll}0 & 0,54 & \mathrm{~b} \\ 2,5 & 4,55 & \mathrm{a} \\ 5,0 & 6,28 & \mathrm{a} \\ 7,5 & 4,93 & \mathrm{a}\end{array}$

* Médias seguidas de letras iquais não diferem significativamente entre si pelo Teste de Tukey - 5\% (CV. 29,00\%). *ᄎ Avaliação feita 40 dias após a inoculação.

Na ausência de BAP, meio contendo macro e micronutrientes e vitaminas, houve uma produção de brotos inexpressiva 
(controle), provavelmente, esta ainda ocorreu como efeito residual do subcultivo anterior em meio contendo esta citocinina. Com a diminuição da concentração deste componente, no entanto, houve estimulo ao enraizamento e tendência maior ao crescimento vertical, com as plântulas apresentando bom vigor.

A concentração de $2,5 \mathrm{mg} / 1$ não foi suficiente para impedir o enraizamento das plântulas, que ocorreu porém de maneira pouco pronunciada.

Como não ocorreram diferenças significativas entre as concentraçóes de BAP utilizadas de 2,5 a $7,5 \mathrm{mg} / 1$, e como existe a indicação da tendência de queda na capacidade de brotação com a elevação da concentração deste regulador de crescimento, acima de $10 \mathrm{mg} / 1$ por GODINHO (1987) em condiçöes in vivo, realizou-se o Experimento 4, o qual foi mais abrangente envolvendo as concentrações de $0 ; 2,5 ; 5,0 ; 7,5 ; 10 ; 12,5 ; 15 ; 17,5$ e $20 \mathrm{mg} / 1$ de BAP, - qual foi avaliado através do peso e número médios de brotos.

Os pesos médios e as médias de brotos obtidos por tratamento estão apresentados na Tabela 4 e no APENDICE 11, para as concentraçōes de BAP citadas acima, durante 45 dias de cultivo em meio semi-sólido.

Avaliando-se os resultados obtidos atraves da pesagem dos brotos, nota-se que apenas a média da testemunha (ausência de citocinina) variou em relação as demais, apresentando a menor média $(4,66 \mathrm{~g})$. As demais não apresentaram diferenças estatisticamente significativas, entre si, estes dados repetem as indicações obtidas através do Experimento 3, onde as concentrações 
de 2,$5 ; 5,0$ e $7,5 \mathrm{mg} / 1$ de BAP não induziram a produção média de brotos com diferença estatística.

Tabela 4. Peso e número médios* de brotos obtidos por parcela (contendo dois ápices caulinares cada) para bananeira "Maçã" (Grupo $A A B$ ) cultivados in vitro sob diversas concentrações de BAP**

CONCENTRAÇÃO DE BAP PESO MEDIO $(\mathrm{mg} / 1)$ (g)
NÜMERO MEDIO

DE BROTOS

\begin{tabular}{|c|c|c|c|c|}
\hline 0 & 4,66 & $b$ & 2,81 & $c$ \\
\hline 2,5 & 11,47 & $a$ & 8,25 & $b$ \\
\hline 5,0 & 16,51 & $\mathrm{a}$ & 16,84 & $\mathrm{a}$ \\
\hline 7,5 & 14,19 & $a$ & 13,69 & $a b$ \\
\hline 10,0 & 13,62 & $a$ & 13,59 & $a b$ \\
\hline 12,5 & 11,20 & $a b$ & 12,19 & $a b$ \\
\hline 15,0 & 12,71 & $a$ & 11,70 & $a b$ \\
\hline 17,5 & 10,88 & $a b$ & 13,42 & $a b$ \\
\hline 20,0 & 15,03 & $a$ & 17,42 & a \\
\hline
\end{tabular}

Quando se lançou mão de avaliação através da contagem do número de brotos, as diferenças aumentaram, a testemunha continuou apresentando a menor média com 2,81 brotos e a concentração de $2,5 \mathrm{mg} / 1$ de $\mathrm{BAP}$ produziu a segunda média $(8,25)$ mais baixa, a qual no entando não diferiu estatisticamente das concentraçöes de 7,$5 ; 10,0 ; 12,5 ; 15,0$ e $17,5 \mathrm{mg} / 1$ de BAP. AS 
concentrações de 5,0 , com 16,84 brotos, e $20,0 \mathrm{mg} / 1$, com 17,42 brotos em média, foram semelhantes estatisticamente, apresentando as maiores médias.

Avaliando-se as médias dos números de brotos para as diferentes concentrações de BAP, pela Tabela 4, observa-se que houve um aumento progressivo da formaça de brotos nos ápices caulinares à medida que se elevou a concentração do regulador de crescimento (BAP), esta tendência ocorreu até a concentração de 5,0 mg/1 desta citocinina, a partir da qual houve leve tendência de queda à aproximadamente $7,5 \mathrm{mg} / 1$, a partir da qual manteve-se praticamente estável até à concentração de $20,0 \mathrm{mg} / 1$, quando houve um estímulo para maior brotação.

Os dados obtidos correspondem parcialmente aos encontrados por GoDINHO (1987), quando trabalhando com plantas de bananeira in vivo, observou que com a adição de BAP, elevava-se a indução de novos brotos até certo ponto $(10,0 \mathrm{mg} / 1)$, a partir do qual havia uma tendência para diminuição. As condições em que o presente trabalho foi realizado distinguem das citadas por este autor, porém, nas condições in vitro, talvez a concentração de 5,0 mg/l de BAP corresponda a este máximo de produção observado, após a qual houve tendência de queda, porém uma tendência ascendente na média de brotos após $10,0 \mathrm{mg} / 1$ não foi observada no trabalho citado.

GUPTA (1986) recomendou a utilização do BAP, nas concentraçōes de 0,7 a $5,0 \mathrm{mg} / 1$, como citocinina indutora de brotações in vitro em Musa. 
BANERJEE \& DE LANGHE (1985) utilizaram $2,3 \mathrm{mg} / 1$ de BAP com $0,18 \mathrm{mg} / 1$ de IAA para manter bananeiras e plátanos sob cultivo mínimo, porém LAMEIRA (1987) trabalhando com outras cultivares de bananeira, recomendou a utilização da concentração de $2,5 \mathrm{mg} / 1$ de BAP para a indução de brotações. No presente trabalho, a ausencia de citocinina promoveu o enraizamento das plantas que atingiram neste periodo $11 \mathrm{~cm}$ em média, com radicelas medindo até $1 \mathrm{~cm}$, lateralmente às raízes principais e a concentração de 2,5 mg/l não impediu o enraizamento, tal enraizamento segundo CRONAUER \& KRIKORIAN (1984b) é desaconselhável, uma vez que diminui o estímulo para a formação de novos brotos. A concentração de 2,5 mg/l de BAP foi, portanto, no presente trabalho, insuficiente para a indução de um brotamento satisfatório em ápices caulinares do cultivar Maçã.

A natureza e a concentração de reguladores de crescimento podem elevar os indices de variação somaclonal, segundo SMITH (1988). Para trabalhos de micropropagação de bananeiras e plátanos, existe uma preocupação no sentido de se diminuir esta variabilidade induzida in vitro, KRIKORIAN (1988a) afirma que frequentemente tem-se obtido percentuais de variantes somaclonais, acima do aceitável para estas culturas. Deste modo, deve-se evitar a utilização do BAP em concentrações elevadas, acima do mínimo indispensável, uma vez que acredita-se que doses elevadas deste componente estariam associadas à intensificação do processo de indução de variantes somaclonais, e isto, para a micropropagação 
comercial, para bancos de germoplasma, assim como para trabalhos com indução de mutação é indesejável.

Para o cultivar Maçã a concentração de $2,5 \mathrm{mg} / 1$ é desaconselhável, uma vez que foi insatisfatória, produziu número baixo de brotos e não foi capaz de impedir o estimulo ao enraizamento do cultivar Maçã, já a concentração de 5,0 $\mathbf{m g} / 1$ parece ser a menor a permitir que os ápices caulinares respondam com maior intensidade ao estímulo da brotação, não havendo indução ao enraizamento para trocas de meio a cada $20-25$ dias.

Em diversas citações, porém, entre as quais CRONAUER \& KRIKORIAN (1986) e SMITH (1988), aparecem referências relacionando a taxa de multiplicação in vitro dos explantes como um dos fatores responsáveis pela elevação da variação de ordem genética ou epigenética do material cultivado. o presente trabalho, então, recomenda a utilização de concentraçôes entre 2,5 e 5,0 mg de BAP para a micropropagação do cultivar Maçã, julga-se que uma concentração deste regulador de crescimento entre 3,5 e 4,0 mg/1 seja suficiente para uma brotação adequada, impedindo o enraizamento e reduzindo a probabilidade de ocorrência de variação somaclonal. Um outro experimento utilizando-se concentrações entre 2,5 e 5,0 mg/1, avaliando o número de brotos e também possiveis variantes somaclonais originados em geraçōes posteriores, talvez possa ser mais conclusivo. 


\subsubsection{Indução de enraizamento de plântulas obtidas in vitro}

Visando-se saber qual o regulador de crescimento e a concentração mais adequados para o enraizamento de plântulas de bananeira "Maçã", realizou-se o Experimento 5, no qual foram testados os reguladores de crescimento IAA, IBA e NAA nas concentrações de $0 ; 0,1 ; 0,5 ; 1,0$ e $5,0 \mathrm{mg} / 1$. Para efeito de avaliação foram obtidos o comprimento e numero médios das raizes e - crescimento médio da parte aérea das plântulas.

A Tabela 5 mostra o comprimento médio de raízes obtido para os reguladores de crescimento IAA, IBA e NAA, em 5 diferentes concentrações $(0,0.1,0.5,1.0$ e $5.0 \mathrm{mg} / 1)$, após 14 dias da inoculação.

As auxinas utilizadas diferiram entre si apenas nas concentrações de 0,1 e $1 \mathrm{mg} / 1$. A menor destas diferiu para 0 regulador de crescimento IAA $(1,95 \mathrm{~cm}$ de raizes, em média) quando comparado com $O \operatorname{IBA}(4,12 \mathrm{~cm})$, sendo que para $\circ \operatorname{NAA}(3,38)$ não houve diferença estatistica. Já o tratamento com $1,0 \mathrm{mg} / 1$ de IAA $(0,73)$ diferiu, para a mesma dose de NAA $(1,76)$, ambas não diferiram, no entanto, estatisticamente do tratamento com IBA.

Na ausência de reguladores de crescimento (controle) houve tendência para maior comprimento médio de raiz $(4,56 \mathrm{~cm})$, como pode ser observado na Tabela 5 e no APENDICE 12. comparando-se as diferentes concentrações, para cada auxina, após o controle, as concentrações mais baixas dos reguladores de crescimento $(0.1 \mathrm{mg} / 1$ 
e $0.5 \mathrm{mg} / 1$ ) tenderam a que apresentar maior comprimento radicular, sendo que a menor destas duas foi aparentemente superior. Já as duas concentrações mais elevadas tenderam a apresentar médias menores para comprimento de raiz.

Tabela 5. Comprimento médio* de raizes (cm) em plantulas de bananeira "Maçã" (Grupo AAB) cultivadas in vitro, através do uso de diversas concentraçōes de auxinas**

\begin{tabular}{|c|c|c|c|c|c|c|c|c|c|}
\hline \multirow{2}{*}{$\begin{array}{c}\text { CONCENTRAÇÃO } \\
(\mathrm{mg} / \mathrm{l})\end{array}$} & \multicolumn{8}{|c|}{ AUXINA } & \\
\hline & \multicolumn{2}{|c|}{ IAA } & \multicolumn{4}{|c|}{ IBA } & \multicolumn{3}{|c|}{ NAA } \\
\hline 0 & 4,56 & $a$ & $A$ & 4.56 & $a$ & A & 4,56 & a & A \\
\hline 0,1 & 1,95 & $\mathrm{~b}$ & $B$ & 4,12 & $a$ & $A$ & 3,38 & $a b$ & $A B$ \\
\hline 0,5 & 2,30 & $b$ & A & 1,70 & $b$ & A & 2,00 & & C A \\
\hline 1,0 & 0,73 & $c$ & B & 1,26 & bc & $A B$ & 1,76 & & C A \\
\hline 5,0 & 0,53 & $c$ & A & 0,34 & c & A & 1,07 & & C A \\
\hline
\end{tabular}

* Medias seguidas de letras iguais minúsculas e maísculas, não diferem significativamente entre si, no sentido vertical e horizontal respectivamente. Avaliação pelo Teste de Tukey - 5\% (CV.22, 24\%) * Avaliação após 14 dias da inoculação.

Para o IAA as concentraçōes de $0,1 \mathrm{mg} / \mathrm{l}$ (com a média de $1,95 \mathrm{~cm})$ houve diferença em relação à testemunha $(4,56 \mathrm{~cm})$, mas não diferiu da concentração de $0,5 \mathrm{mg} / 1$ (com 2,30 cm), ambas diferiram, porém, das concentrações de $1,0 \mathrm{~m} / 1(0,73)$ e $5,0 \mathrm{mg} / 1$ $(0,53)$. 
A concentração de $0,1 \mathrm{mg} / 1$ de IBA, com $4,12 \mathrm{~cm}$ de raiz, não diferiu da testemunha $(4,56 \mathrm{~cm})$, porém mostrou-se superior quando comparada às demais concentrações do mesmo regulador de crescimento. A concentração de $0,5 \mathrm{mg} / 1$, com a média de $1,74 \mathrm{~cm}$ de raiz, também apresentou diferença estatística em relação à concentração de $0,5 \mathrm{mg} / 1(0,34 \mathrm{~cm})$. As concentrações de 0,5 e $1,0 \mathrm{mg} / 1$ de IBA não apresentaram diferenças significativas entre si.

Para o regulador de crescimento NAA as diferenças ocorreram para a concentração de $0,1 \mathrm{mg} / 1(3,38 \mathrm{~cm})$, embora não tenha diferido do controle, quando comparada com as concentrações de $1,0(1,76 \mathrm{~cm})$ e $5,0 \mathrm{mg} / 1(1,07 \mathrm{~cm})$, mostrou-se superior.

A avaliação de um bom enraizamento, porém, não pode ser feita com base apenas em um bom comprimento de raiz, uma vez que, observou-se comparando as Tabelas 5 e 6 , que existiram tratamentos que, embora tenham produzido bom comprimento médio, tenderam a produzir menor número de raízes, como foi o caso da testemunha (ausência de reguladores de crescimentos). A Tabela 6 e - APENDICE 13 apresentam o número médio de raízes induzido durante os 14 dias de cultura nas plântulas de bananeira "Maçã", com os reguladores de crescimento utilizados (IAA, IBA e NAA), nas diferentes concentrações.

Os reguladores de crescimento não apresentaram, para - número médio de raízes, diferenças significativas entre si, sendo que como já observado para o comprimento médio de raízes, as 
concentrações mais baixas $(0,1$ e $0,5 \mathrm{mg} / 1)$ tenderam a apresentar também maior número de raízes, em média.

Tabela 6. Número médio* de raizes em plântulas de bananeira "Maçã" cultivadas in vitro, durante enraizamento através de diversas concentraçöes das auxinas IAA, IBA e NAA**

\begin{tabular}{|c|c|c|c|c|c|c|c|c|c|}
\hline \multirow{2}{*}{$\begin{array}{c}\text { CONCENTRAÇÃO } \\
(\mathrm{mg} / 1)\end{array}$} & \multicolumn{8}{|c|}{ AUXINA } & \\
\hline & IAA & & & IBA & & & NAP & & \\
\hline 0 & 3,75 & $a b$ & $A$ & 3,75 & a & A & 3,75 & $a b$ & $A$ \\
\hline 0,1 & 5,32 & $a b$ & A & 5,08 & a & $A$ & 6,70 & $a$ & $\mathbb{A}$ \\
\hline 0,5 & 5,89 & $a$ & $\mathrm{~A}$ & 4,78 & a & $A$ & 4,00 & $a b$ & $A$ \\
\hline 1,0 & 3,74 & $a b$ & A & 3,42 & $\mathrm{a}$ & $A$ & 3,75 & $a b$ & $A$ \\
\hline 5,0 & 3,05 & $b$ & $A$ & 3,38 & $\mathrm{a}$ & A & 3,12 & $\mathrm{~b}$ & $\AA$ \\
\hline
\end{tabular}

Médias seguidas de letras iquais minúsculas e maiúsculas, não diferem significativamente entre si, no sentido vertical e horizontal respectivamente. Avaliação pelo Teste de Tukey - 5\% (CV.23,77\%) * Avaliação após 14 dias da inoculação.

Como é possível notar na Tabela 6 , para o regulador de crecimento IAA, estatisticamente houve diferença entre as concentrações de $0,5 \mathrm{mg} / 1$ e $5,0 \mathrm{mg} / 1$, onde a menor concentração induziu a formação de um maior número médio de raízes $(5,89)$.

Para o regulador de crescimento IBA, não houve diferenças estatisticas entre o número médio de raízes induzido pelas diferentes concentrações, sendo que as concentrações de 0,1 e $0,5 \mathrm{mg} / 1$ tenderam a apresentar melhores respostas. 
Houve diferença significativa estatisticamente para - NAA, entre as concentrações de $0,1 \mathrm{mg} / 1$ e $5,0 \mathrm{mg} / 1$, também neste caso a menor concentração foi capaz de induzir a formação de maior número de raizes por planta em média $(6,70)$.

Embora para o comprimento de raízes a ausência de reguladores de crescimento tenha resultado em maiores médias, para - numero de raizes esta tendência se alterou, uma vez que as menores concentraçōes de reguladores estimularam a formação de maior número de raizes, em relação ao controle.

Além do comprimento e número médios de raízes induzidas nas diferentes concentrações das três auxinas utilizadas, realizou-se avaliações quanto ao crescimento de parte aerea das plântulas de bananeira durante o processo de enraizamento. A Tabela 7 e O APENDICE 14 representam o crescimento médio da parte aérea, de plântulas de bananeira "Maçã" cultivadas in vitro, sob indução de enraizamento através das auxinas IAA, IBA e NAA, nas diferentes concentrações.

Os diferentes reguladores testados não apresentaram diferenças significativas entre si, para a maioria das concentraçôes utilizadas. A concentração de $0,5 \mathrm{mg} / 1$ de IAA, no entanto, apresentou diferença para a média de crescimento de parte aérea das plântulas, em relação a mesma concentração de IBA, enquanto o primeiro tratamento permitiu o crescimento de parte aérea em 1,04 $\mathrm{cm}$, o segundo induziu apenas $0,30 \mathrm{~cm}$ de crescimento. 
Tabela 7. Crescimento medio* (cm) de plantulas de bananeira "Maçã" (Grupo AAB) cultivadas in vitro, através do uso de diversas concentrações de auxinas.

AUXINA

CONCENTRAÇÃO

IAA

IBA

NAA

(mg/I)

\begin{tabular}{|c|c|c|c|c|c|c|c|c|c|}
\hline 0 & 1,08 & $a$ & $A$ & 1,08 & a & $A$ & 1,08 & a & $A$ \\
\hline 0,1 & 1,19 & $a$ & $A$ & 0,53 & $a$ & $A$ & 0,56 & a & $\mathbf{A}$ \\
\hline 0,5 & 1,04 & $a$ & $\mathrm{~A}$ & 0,30 & $a$ & $B$ & 0,81 & a & $A B$ \\
\hline 1,0 & 0,78 & $a$ & $A$ & 0,51 & $a$ & $A$ & 0,54 & $\mathrm{a}$ & $\AA$ \\
\hline 5,0 & 0,67 & $a$ & A & 0,36 & $a$ & $A$ & 0,65 & $a$ & $A$ \\
\hline
\end{tabular}

Já as diferentes concentraçōes, para cada regulador de crescimento, não permitiram crescimento diferenciado de parte aérea das plântulas do cultivar Maçã. Comparando-se as três tabelas apresentadas, observa-se que, de um modo geral a concentração de $0.1 \mathrm{mg} / 1$ dos reguladores de crescimento NAA e IBA foram eficientes para um bom enraizamento de plântulas do cultivar Maçã. LAMEIRA (1987) trabalhando com outros cultivares de bananeira, sugeriu a utilização de $5 \mathrm{mg} / 1$ de IBA para o enraizamento de plâtulas, no presente trabalho, no entanto, notou-se que não são necessárias concentrações superiores a $0,1 \mathrm{mg} / 1$ para uma boa indução de enraizamento das plântulas. 
Como a presença de auxinas inibe o crescimento da parte aérea das plântulas durante o enraizamento, o que também foi observado por VUYLSTEKE \& DE LANGHE (1985), os quais utilizando o IBA, notaram que ocorreu paralização gradual do crescimento com a elevação deste componente, recomenda-se não utilizar auxinas durante o processo de micropropagação.

Observou-se, no presente trabalho, que os brotos obtidos através da utilização do BAP como citocinina, podem enraizar quando a concentração deste componente é diminuida no meio de cultura, a capacidade de brotação, então, é diminuía e quando objetiva-se a produção de um número grande de brotos, deve-se induzir o enraizamento em um passo seguinte, a necessidade deste procedimento também foi frisada por CRONAUER \& KRIKORIAN (1984b). - enraizamento pode, então, ser realizado na ausência de reguladores de crescimento, como pode ser visualizado nas Tabelas 5 e 6 onde o controle, sem reguladores de crescimento, apresentou um bom nivel de enraizamento, o que também foi observado por CRONAUER \& KRIKORIAN (1984b), VUYLSTEKE \& DE LANGHE (1985) e WONG (1986).

Notou-se durante o cultivo in vitro de bananeira, que a diminuição das concentrações de citocinina (BAP) estimulam o enraizamento, isto indica que as plântulas de Musa são bastante eficientes na produção de auxinas, no entanto, percebe-se que a partir dos dados apresentados, que baixas concentrações $(0,1$ a 0,5 mg/1) de IAA, IBA ou NAA, tenderam a estimular a formação de maior 
número médio de raizes em relação ao controle, o que pode ser observado na Tabela 6 .

Dentre os três reguladores de crescimento utilizados neste trabalho, o mais usado em trabalhos de cultura de tecidos é - NAA (53\% dos casos) seguido do IBA (29\% dos casos) e do IAA (11\% dos casos), segundo HU \& WANG (1983).

LAMEIRA (1987) recomendou manter plântulas de bananeira durante 1 semana em meio contendo $5,0 \mathrm{mg} / 1$ de IBA, após este período, recomendou transferi-las para meio de cultura contendo a metade das concentrações de sais minerais e ausência de reguladores de crescimento, ZIMMERMAN \& BROOME (1981), no entanto, trabalhando com o enraizamento de plântulas de macieira obtidas in vitro conseguiram evitar duas etapas, utilizando baixas concentraçōes de auxinas.

No presente trabalho notou-se que baixas concentraÇões das auxinas NAA e IBA $(0,1 \mathrm{mg} / 1)$, foram capazes de induzir um enraizamento satisfatório após 1 ou 2 semanas e, nestas concentrações, foi desnecessária a transferência das plântulas para outro meio, podendo-se após 14 ou 20 dias transferi-las para casa de vegetação, tornando o processo de enraizamento mais prático e menos dispendioso. Com relação a qual dos reguladores de crescimento utilizar, chegou-se à conclusão de que pode-se utilizar os três (NAA, IBA OU IAA) pois foram capazes de produzir bom enraizamento em plântulas de bananeira em baixas concentrações $(0,1$ e 0,5 $\mathrm{mg} / 1)$. No que se refere a qual das concentrações utilizar $(0,1$ ou $0,5 \mathrm{mg} / 1$ ), recomenda-se a utilização de $0,1 \mathrm{mg} / 1$ para o NAA ou IBA, 
podendo-se optar pelo mais disponivel a um menor custo, para o IAA, no entanto, caso se deseje utilizá-1o com a finalidade de enraizamento de plantulas de bananeira, recomenda-se a utilização de 0,5 $\mathrm{mg} / 1$, uma vez que visualmente foi a melhor concentração deste regulador de crescimento para o enraizamento do cultivar Maçã.

\subsection{Radiossensitividade de ápices caulinares de bananeira cultivar maçã (grupo AAB)}

Os resultados obtidos no Experimento 6, de radiossensitividade, podem ser observados na Tabela 8 e no APENDICE 15 , através da qual pode-se observar o número médio de brotos originados dos explantes irradiados através do tempo. A dose de 20 Gy não diferiu estatisticamente do controle, embora as médias de multiplicạão dos ápices caulinares que receberam este tratamento tivessem tendido a superar as médias obtidas pelos explantes não irradiados.

Pode-se observar na tabela 8 que a dose que provocou uma redução em aproximadamente $50 \%$ nas brotações durante as 5 quinzenas de cultivo, foi a de $40 \mathrm{~Gy}$, a qual permitiu a produção de uma média de 6,37 brotos em média após 75 dias de cultivo, enquanto que, para este mesmo espaço de tempo, a dose de 60 Gy inibiu a capacidade de brotamento dos explantes, produzindo apenas 0,47 brotos. 
Tabela 8. Número médio* de brotos obtidos através do tempo de cultivo in vitro de apices caulinares de bananeira

Maçã", após irradiação com raios gama

\begin{tabular}{ccccccccccc}
\hline DOSE & \multicolumn{7}{c}{ TEMPO (dias) } \\
(Gy) & 15 & 30 & 45 & 60 & & 75 \\
\hline 0 & 1,51 & $a$ & 2,91 & $a$ & 4,47 & $a$ & 5,34 & $a b$ & 9,70 & $b$ \\
20 & 1,64 & $a$ & 2,75 & $a$ & 4,19 & $a b$ & 6,19 & $a$ & 13,19 & $a$ \\
40 & 1,07 & $a$ & 1,96 & $a$ & 2,55 & $b$ & 3,92 & $b$ & 6,37 & $c$ \\
60 & 0,05 & $b$ & 0,05 & $b$ & 0,09 & $c$ & 0,21 & $c$ & 0,47 & $d$ \\
100 & 0,00 & $b$ & 0,00 & $b$ & 0,00 & $c$ & 0,00 & $c$ & 0,00 & $d$ \\
\hline
\end{tabular}

* Médias seguidas de letras iguais não diferem, na vertical, significativamente entre si pelo Teste de Tukey - 5\% (CV. $31,15 \%)$

As doses de 80 e 100 Gy provocaram oxidaçōes elevadas nos explantes irradiados, formando uma crosta espessa em torno dos mesmos impedindo sua brotação e consequentemente levando a sua morte.

Já no Experimento 7 , mais recente, procurou-se uma outra maneira de se avaliar a radiossensitividade através do peso médio de brotos formados. A Tabela 9 e 0 APENDICE 16 mostram o ganho médio de peso em ápices caulinares de bananeira cultivar Maçã cultivados in vitro, após irradiação com fonte de raios gama.

Comparando-se os pesos médios dos brotos obtidos, nas diversas doses utilizadas, pode-se observar que as doses de 0 
e 20 Gy não diferiram significativamente entre si e, como no experimento anterior, as brotações obtidas a partir de ápices caulinares irradiados com $20 \mathrm{~Gy}$ tenderam a apresentar peso médio superior às médias da testemunha, não irradiada.

Tabela 9. Ganho de peso médio* em ápices caulinares de bananeira Maçã cultivados in vitro irradiadas com radiação gama.

DOSE

(Gy) 1 Semana 2: Semana 3: Semana 4 Semana 5 Semana

\begin{tabular}{rrrrrrrrrrr}
\hline 0 & 2,09 & $a$ & 3,05 & $a b$ & 3,91 a & 4,83 a & 5,61 a \\
20 & 2,26 a & 3,32 a & 4,08 a & 5,19 a & 6,12 a \\
40 & 1,95 a & 2,65 ab & 3,25 ab & 4,03 a & 4,77 a \\
60 & 1,77 a & 2,14 & b & 2,34 & b & 2,65 & $b$ & 2,99 & $b$
\end{tabular}

Médias seguidas de letras iguais não diferem significativamente entre si, na vertical, pelo Teste de Tukey - 5\% (CV. 11,37)

As médias de peso obtidas para as doses de 0,20 e 40 Gy não difexiram estatisticamente neste tempo, enquanto que as mesmas diferiram significativamente, para a $4^{\text {a }} 5^{\text {semanas, }}$ quando comparadas às médias referentes à dose de $60 \mathrm{~Gy}$.

Segundo as Tabelas 8 e 9, apresentadas, as doses de 40 Gy e 60 Gy diminuiram sensivelmente a multiplicação e o crescimento dos explantes. A dose de 20 Gy não diferiu significativamente do controle, embora apresentasse sempre um leve estímulo à capacidade de brotação dos explantes; tal tendência também foi observada por DE GUSMAN et al. (1982), quando irradiaram 
ápices caulinares de diversos clones com baixas doses de raios gama $(10-25 \mathrm{GY})$.

As doses adequadas de exposição dos ápices caulinares de Musa cultivados in vitro foram calculadas com base na redução do crescimento em $50 \%$ e no performance em relação ao controle não irradiado, tal procedimento também foi realizado por NOVAK et al. (1990).

No presente trabalho, os resultados obtidos através do número médio de brotos, mostram claramente o efeito da radiação, sendo que a redução na capacidade de brotação pela metade ocorreu por volta da dose de $40 \mathrm{~Gy}$, devendo ser esta portanto a dose a ser escolhida para trabalhos con indução de mutações em ápices caulinares do cultivar Maçã. Estes dados correspondem aos resultados obtidos por NOVAK et al. (1986), os quais chegaram a conclusão que o $\mathrm{LD}_{50}$ para ápices caulinares de bananeira, situa-se entre 30 - 45 GY, Já NOVAK et al. (1990) trabalhando com sete clones de diversos grupos genômicos de bananeira, chegaram à conclusão de que havia diferença de radiossensitividade entre os grupos genômicos de bananeira, sendo que a sensibilidade dos explantes diplóides era maior, que a dos triplóides e que por sua vez era maior que a apresentada pelos tetraplóides; para o grupo $A A B$, o mesmo ao qual pertence o cultivar Maçã, estes autores chegaram à dose de 40 Gy como sendo $0 \mathrm{LD}_{50}$.

Para o presente trabalho, a dose letal para os explantes foi de aproximadamente $80 \mathrm{~Gy}$, enquanto que para GUZMAN et al. (1976) a dose letal foi aproximadamente $200 \mathrm{~Gy}$, provavelmente 
devido à utilização de metodologia (irradiação e posterior extração dos ápices para cultivo in vitrol e cultivar diferentes.

Quando a avaliação se deu por pesagens a redução do peso pela metade deu-se por volta de $60 \mathrm{~Gy}$. O que demonstra que as doses escolnidas para indução de mutações poden variar, de acordo com o parâmetro escolhido ( $\mathrm{LD}_{50}$ ou $\mathrm{GR}_{50}$ ).

A avaliação através de pesagens permitiu observar que, embora em doses elevadas como 40 e 60 Gy ocorra atraso na brotação dos explantes, estes apresentam crescimento em diâmetro e consequentemente ganho de peso, o que não poderia ser quantificado pela simples contagem do número de brotos.

NOVAK et al. $(1986,1987$ e 1990), realizaram ensaios de radiossensitividade, os quais foram avaliados através do número e peso médios dos brotos formados, utilizando para isto tanto o meio líquido como o sólido, e observaran que o meio líquido foi superior em qualidade e velocidade de resposta dos explantes ao tratamento com radiação gama, os quais foram avaliados por 30 dias. o presente trabalho utilizou meio semi-sólido, e por isto, o tempo necessário para avaliação foi maior 160 - 75 dias, segundo Tabela 8), tanto para a avaliação através do peso quanto do número médios de brotos formados.

A análise da capacidade de brotação através do tempo indicou que as doses de radiação até 60 GY não impediram a formação de brotos, enquanto que as doses de 80 e 100 Gy foram letais. Quanto ao número médio de brotos formados, notou-se 
uma tendência de maior brotação com o passar do tempo para as doses que permitiram a sobrevivência dos explantes ( 20 a 60 Gy), sendo que esta capacidade foi maior para o controle e 20 Gy e menor para $40 \mathrm{~Gy}$ que por sua vez foi maior que $60 \mathrm{~Gy}$.

Como em trabalhos de indução de mutação de plantas de propagação vegetativa, é necessária a obtenção de um grande numero de plantas após o tratamento mutagênico, para as condições em que foi realizado o presente trabalho, escolheu-se como melhor, - método de avaliação da radiossensitividade através da contagem do número de brotos, referente ao Experimento 6, como sendo mais eficiente, e a dose ideal para trabalhos visando a indução de mutaçöes em plantas pertencentes ao cultivar Maçã (grupo AAB) é de $40 \mathrm{~Gy}$, obtido através do $L D_{50}$.

\subsection{Isolamento dos setores utados}

Esta fase possui grande importância em trabalhos de indução de mutações, devido o quimerismo induzido quando são tratados tecidos multicelulares, como os ápices meristemáticos, com mutagênicos. SPIEGEL-ROY (1990), cita o isolamento dos setores mutados, em plantas de propagação vegetativa, como uma das principais dificuldades apresentadas para o melhoramento genetico das mesmas através da indução de mutação.

Assim como NOVAK et al. (1986) foram observadas oxidações nos explantes irradiados, e esta tendência aumentou à 
medida em que as doses de radiação foram maiores, os explantes irradiados com 80 e 100 Gy não chegaram a produzir brotaçóes tal a intensidade de enegrecimento provocado como efeito fisiológico à irradiação.

Os explantes irradiados nas doses de 0 e 20 Gy apresentaram boa capacidade de propagação e estes brotos tendiam a crescer verticalmente e a enraizar. No entanto, alguns poucos explantes irradiados com 40 e a maioria dos irradiados com $60 \mathrm{~Gy}$, tenderam a atrasar o início das brotações, havendo um crescimento dos tecidos rizomatosos, formando estruturas atípicas, que não ocorreram em explantes não irradiados, estas alterações no desenvolvimento dos explantes, não foram citadas por NovAK et al. (1986 e 1990) quando irradiaram ápices caulinares de diversos clones de bananeira, visando indução de mutações.

BROERTJES \& VAN HARTEN (1988) comentam que células que sofreram danos fisiologicos ou cromossômicos, apresentam uma menor capacidade mitótica em relação às células que não sofreram estes efeitos, mas afirmam que mutações gênicas simples ou mesmo deleções menores não alteram necessariamente a capacidade de competição da célula. No presente trabalho observou-se inicialmente, um atraso para a brotação destas estruturas induzidas pela irradiação com as doses mais elevadas ( 40 e 60 Gy) entretanto, após este atraso inicial houve uma boa capacidade para a formação de novos brotos.

Para a bananeira, assim como para outras culturas, não se sabe exatamente qual é o número mínimo de gerações a se 
avançar, no sentido de se individualizar os setores mutados, adquirindo-se assim mutantes estáveis (sólidos ou periclinais). NOVAK et al. (1986) trabalhando com Musa não chegaram a definir um número exato de gerações, porém em trabalhos posteriores, NOVAK et al. (1989), sugeriram que fossem realizadas multiplicações clonais por quatro gerações vegetativas.

- presente trabalho tamben estabeleceu no mínimo quatro gerações, para o isolamento dos setores mutados. Durante o processo de multiplicação e desenvolvimento dos brotos nesta geração foi possivel observar, ainda in vitro, algumas alterações fenotipicas para a pigmentação das folhas. Foram observadas plantas, as quais apresentaram folhas com variegacão bastante definida, em tons de verde e branco (PVVB) ou verde e amarelo-claro (PVVA).

Estas alterações ocorreram para as doses de 40 e 60 Gy, na geração $M_{2} V_{4}$, que não foi observado nas gerações anteriores, já para o controle não ixradiado, assim como para as brotações originadas pelo tratamento com 20 não foram observadas alterações in vitro.

os dados observados in vitro, foram confirmados pelos resultados obtidos posteriormente em casa de vegetação e inaicam que quatro geraçōes foram suficientes para que setores mutados para pigmentação e clorofila (alterações fenotipicas de fácil observação) se manifestassem. Não é possivel saber-se, no entanto, o número de gerações que seriam necessarias para que mutantes resistentes à doença ou mais produtivos poderiam ser 
obtidos, uma vez que possuem maior dificuldade de obtenção e constatação.

Estas alterações de ordem fenotipica poderiam sugerir que a utilização de doses mais elevadas seriam mais adequadas para a irradiação de um determinado tipo de explante, apenas porque esta permitiu a manifestação de alteraçōes de fácil constatação, no entanto, muitas vezes estas podem estar associadas a aberrações cromossômicas, causadoras de grandes alteraçōes genéticas. BROERTJES \& VAN HARTEN (1988) afirmaram que para o melhoramento genético de plantas a indução de mutação objetiva a alteração de uma ou poucas características de materiais de boa aceitação. Podendo ocorrer então, que doses menores venham a contribuir mais para a aquisição de pequenas alteraçōes, induzidas por mutações gênicas, de maior interesse para o melhoramento de plantas.

As multiplicações dos ápices caulinares irradiados, no presente trabalho, mostraram-se satisfatórias sendo que foi obtido o número esperado de plantas para serem destinadas à casa de vegetação, de aproximadamente 3000 plantas no quarto e último ciclo vegetativo.

\subsection{Aclimatação das plântulas em solo}

As plântulas, possuindo de $6-9 \mathrm{~cm}$ de altura, apresentaram boa resposta ao transplante, sendo que as perdas foram 
minimas ( 3 - 5\%), em casa de vegetação, quando originadas de enraizamento realizado em meio sólido ou semi-sólido. As perdas, no entanto, elevaram-se para $20 \%$ quando as plantulas foram obtidas do cultivo em meio liquido, observando-se o ataque por microorganismos na região do colo das plantas. VUYLTEKE \& DE LANGHE (1985) também utilizaram meio semi-sólido para enraizamento e aclimatando plantas de 6 - $10 \mathrm{~cm}$ de comprimento obtiveram $100 \%$ de pegamento em solo.

KRIKORIAN \& CRONAUER (1984b) e CRONAUER \& KRIKORIAN (1984b) e CRONAUER- MITRA \& KRIKORIAN (1986) após enraizarem plantas em meio semi-solido, realizaram aclimatação das mesmas em recipientes com vermiculita e mantiveram sob nebulização por 10 a 14 dias, após o que puderam ser transferidas para casa de vegetação. Para o presente trabalho foram utilizados mistura de solo, como substrato, composto de solo argiloso, esterco e areia, na proporção de 1:1:1 e os resultados foram favoráveis, e não foram necessarios mais do que 4 - 5 dias sob nebulização, para a transferência para a casa de vegetação.

Recomenda-se, então, a passagem de brotos originados do cultivo em meio líquido para o meio sólido ou semi-sólido durante a fase de enraizamento de modo a garantir maior vigor para as plantas antes da aclimatação em casa de vegetação. Pode-se utilizar solo como substrato, e de preferência utilizar nebulização nos primeiros 4 - 5 dias de aclimatação, evitando-se porém que o solo fique enxarcado. 


\subsection{Isolamento do Fusariun ozysporula f. sp.} cubense

O reconhecimento da raça 1 causadora da Fusariose no cultivar nacional Maçã, foi feito com base em literatura e resultados de inoculações em plantas consideradas resistentes e susceptiveis à esta raça do patogeno. Segundo su et al. (1986) esta raça, apos o seu aparecimento no Panamá em 1904 , dispersou-se pelo mundo todo, já a raça 2 é encontrada, até o momento na América central, onde é endêmica ao cultivar Bluggloe (grupo AAB). Segundo WAITE (1963) e LEHMANN-DANZINGER (1986) a raça 3 é endêmica em espécies selvagens de Heliconia spp e SUN \& KO (1978) isolaram uma nova raça do fungo ( raça 4) a qual, no entanto, é patogênica a cultivares do grupo Cavendish, consideradas até o momento como sendo resistentes à Fusariose.

Com relação à susceptibilidade dos cultivares nacionais às diversas raças do fungo, muito pouco se sabe, o que pode ser observado através do APENDICE 5. O cultivar Maçã, segundo indicações de SHEPHERD (1983), pode possuir o mesmo genótipo do cultivar exógeno silk, a qual por sua vez é susceptível à raça 2 da Fusariose, o que sugere a possivel susceptibilidade do cultivar nacional a esta raça do patógeno.

Durante o isolamento do fungo pertencente à raça 1 da Fusariose da bananeira, ocorreram alguns casos de contaminação com fungos saprofiticos, porém muitas das placas inoculadas com o explante inicial permitiram o isolamento do Fusarium oxysporum 
f.sp. cubense. Foi observado que explantes do rizoma infectado com maior necrose possibilitou maiores indices de contaminação com bactérias ou fungos saprofiticos, e que explantes com sinais menos expressivos do ataque do fungo são mais adequados para o isolamento.

Como esperado, o Fusarium, respondeu muito bem ao BDA, com bom desenvolvimento em placa de petri, apresentando padrão de crescimento semelhante ao observado por su et al. (1986), quando utilizaram o meio $\mathrm{K}_{2}$ com a finalidade de se distinguir o crescimento das raças 1,2 e 4 do patógeno.

Após o seu desenvolvimento foram realizadas as suspensões de esporos e hifas do fungo, a qual foi inoculada em plantas jovens do cultivar Maçã (susceptivel) e do cultivar Nanicão (resistente), as primeiras apresentaram sintomas após 20 dias, enquanto que as outras não sofreram danos, como esperado. Após este teste de patogenicidade do isolado do fungo, foi então realizado o Experimento 8 para a avaliação do tempo ideal de cultivo do fungo em BDA, para fins de coleta de espóros e hifas para a inoculação das plantas jovens de bananeira cultivar Maçã.

A Tabela 10 e o APÉNDICE 17 mostram o número médio de esporos produzidos através do tempo, pelo fusarium oxysporum f.sp. cubense, quando cultivado em BDA.

Os resultados mostraram que em 15 dias de cultivo, as hifas do fungo cobriram totalmente as placas de Petri. Foram coletadas amostras do material fúngico em cultivo que mostrou que - tempo em cultura ideal, contendo maior número de esporos foi aos 
15 dias após este tempo ocorreu diminuição do número de esporos até os 60 dias de cultivo, como indica a Tabela 10.

Tabela 10. Número médio* de esporos produzidos através do tempo pelo Fusarium oxysporum f.sp. cubense cultivado em BDA

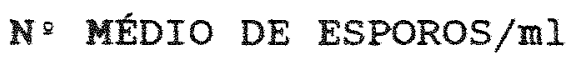

$\begin{array}{llc}7 \text { dias } & 56,387 \times 10^{4} & \mathrm{~b} \\ 15 \text { dias } & 80,051 \times 10^{4} & \mathrm{a} \\ 25 \text { dias } & 44,497 \times 10^{4} & \mathrm{c} \\ 38 \text { dias } & 38,895 \times 10^{4} & \mathrm{c} \\ 60 \text { dias } & 18,573 \times 10^{4} & \mathrm{~d}\end{array}$

* Médias seguidas de letras iguaís não diferem significativamente entre si pelo Teste de Tukey - 5\%

Após uma semana em cultivo a produção de esporos já havia atingido, em média, $56,4 \times 10^{4}$ esporos/ml, enquanto que aos 15 dias atingiu $80 \times 10^{4}$ esporos $/ \mathrm{ml}$, aproximadamente. Este foi o tempo no qual toda a placa de Petri ficou recoberta com o fungo, e onde ocorreu maior produção de esporos e foi para as condições de cultivo utilizadas, o tempo ideal, uma vez que havia a necessidade de uma grande quantidade de esporos para confeção da suspensão para a inoculação das plantas em casa de vegetação.

A partir do 158 dia ocorreu uma queda significativa estatisticamente até o $25^{\circ}$ dia $\left(44,497 \times 10^{4}\right.$ esporos $/ \mathrm{ml}$, em média), a partir do qual ocorreu decrescimo no número de esporos que pros- 
seguiu gradativamente, sem diferenças estatisticamente perceptíveis, até $038^{\circ}$ dia $\left(38,895 \times 10^{4}\right.$ esporos/ml).

Aos 60 dias de cultivo o número de esporos apresentou sua maior queda $\left(18,473 \times 10^{4}\right.$ esporos/m1). Estes resultados obviamente estão ligados a perda da qualidade nutricional do meio de cultura utilizado (BDA). Enquanto haviam condiçóes ideais as hifas do fungo se expandiram e produziram esporos, quando tais condições começaram a apresentar limitaçōes, os esporos presentes continuaram a germinar, mas a sua produção foi diminuindo, o que resultou numa diminuição dos valores finais observados até os 60 dias de cultivo.

\subsection{Inoculação en casa de vegetação}

As inoculações realizadas utilizando-se $50 \mathrm{ml}$ de suspensão, contendo $5 \times 10^{4}$ esporos/ml da raça 1 do Fusarium, por planta de bananeira "Maçã", permitiram observar sintomas a partir de 20 dias de sua realização de maneira que pôde-se facilmente constatar a susceptibilidade das plantas, tais dados confirmam o já observado por SUN \& SU (1984) e MENDES et al. (1989).

As plantas foram inoculadas em 2 etapas, a primeira constou de 1011 plantas, sendo 411 do controle e as demais, dos tratamentos de 20,40 e $60 \mathrm{~Gy} ;$ a segunda de 1754 plantas, sendo 485 do controle e as demais nas doses já citadas. Ao todo foram 
inoculadas 2765 plantas, sendo que foram então quantificadas as plantas que apresentaram sintomas, as que devido à infestação com - fungo posteriormente morreram e as que apresentaram recuperação e puderam ser reinoculadas.

A Figura 4 mostra a sequência utilizada, no presente trabalho, durante $\circ$ processo de seleção de plantas resistentes à Fusariose e a Tabela 11 apresenta os resultados obtidos no Experimento 9, durante a fase de inoculação de plantas jovens do cultivar Maçã, originadas após subcultivo por quatro geraçōes vegetativas $\left(M_{2} V_{4}\right)$ de ápices caulinares irradiados (doses de 20,40 e $60 \mathrm{~Gy}$ ) e não irradiados (testemunha), com suspensão da raça 1 do Fusarium.

Do total de plantas inoculadas (NPI) todas apresentaram, de maneira mais intensa ou menos intensa, sintomas da Fusariose, isto significa que até o momento não foi possível obter plantas resistentes ao fungo.

As plantas que apresentaram sintomas (NPA) o fizeram de maneira diferenciada, a maioria delas após o ataque pelo fungo morreu (NPM), não apresentando qualquer resposta que indicasse uma possivel sobrevivência ao ataque. Algumas plantas logo após o aparecimento de sintomas, permitiam a continuação do desenvolvimento da gema apical, o que normalmente ocorria através de rachaduras no antigo pseudocaule atacado. Outro tipo de reação apresentada foi a emissão de brotações laterais, as quais possuiam relativo vigor. 
Plantas do Campo

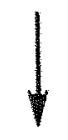

Extraçāo de meristemas, micropropagaçāo "in vitro", e obtencāo de ápices caulinares

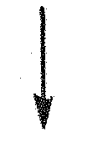

Irradiaçāo dos ápices caulinares $\left(M_{1} V_{0}\right)$ "in vitro"

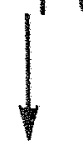

Multiplicaçāo por 4 geraçōes vegetativas $\left(M_{1} V_{4}\right)$

Aclimataçāo das plantas em recipientes com solo autoclavado

Selecāo em campo

contaminado com o

Fusarium

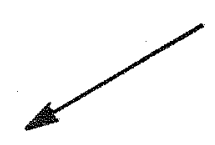

.

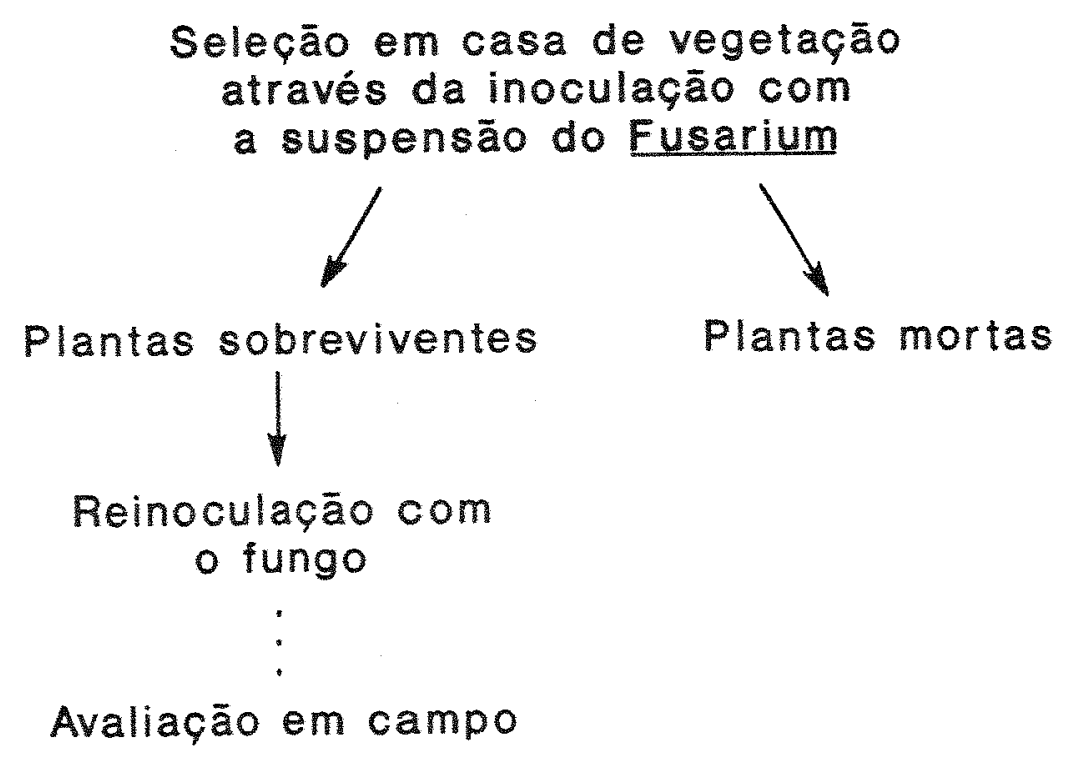

Seleçāo em casa de vegetaçāo através da inoculaçāo com a suspensāo do Fusarium

obreviventes

Figura 4 - Esquema utilizado para os trabalnos de seleção de plantas de bananeira cultivar Maçã (grupo AAB) resistentes ao Fusarium oxysporum f.sp. cubense. 
Estas plantas sobreviventes (NPS) foram mantidas em casa de vegetação e puderam ser re-inoculadas, caso o inóculo remanescente não fosse suficiente para a manifestação da doença.

Deste modo as remanescentes voltaram a apresentar sintomas $e$, novamente houve plantas que morreram e outras que reagiram ao ataque atraves das duas maneiras explicadas anteriormente, de modo que em um primeiro estágio haviam plantas sobreviventes $\left(\right.$ NPS $\left._{1}\right)$ e em um segundo estágio este número foi reduzido $\left(\mathrm{NPS}_{2}\right)$

Tabela 11. Inoculação de plantas jovens* de bananeira "Maçã" (grupo AAB) com Fusarium oxysporum f. sp. cubense, obtidas após irradiação e micropropagação de ápices caulinares.

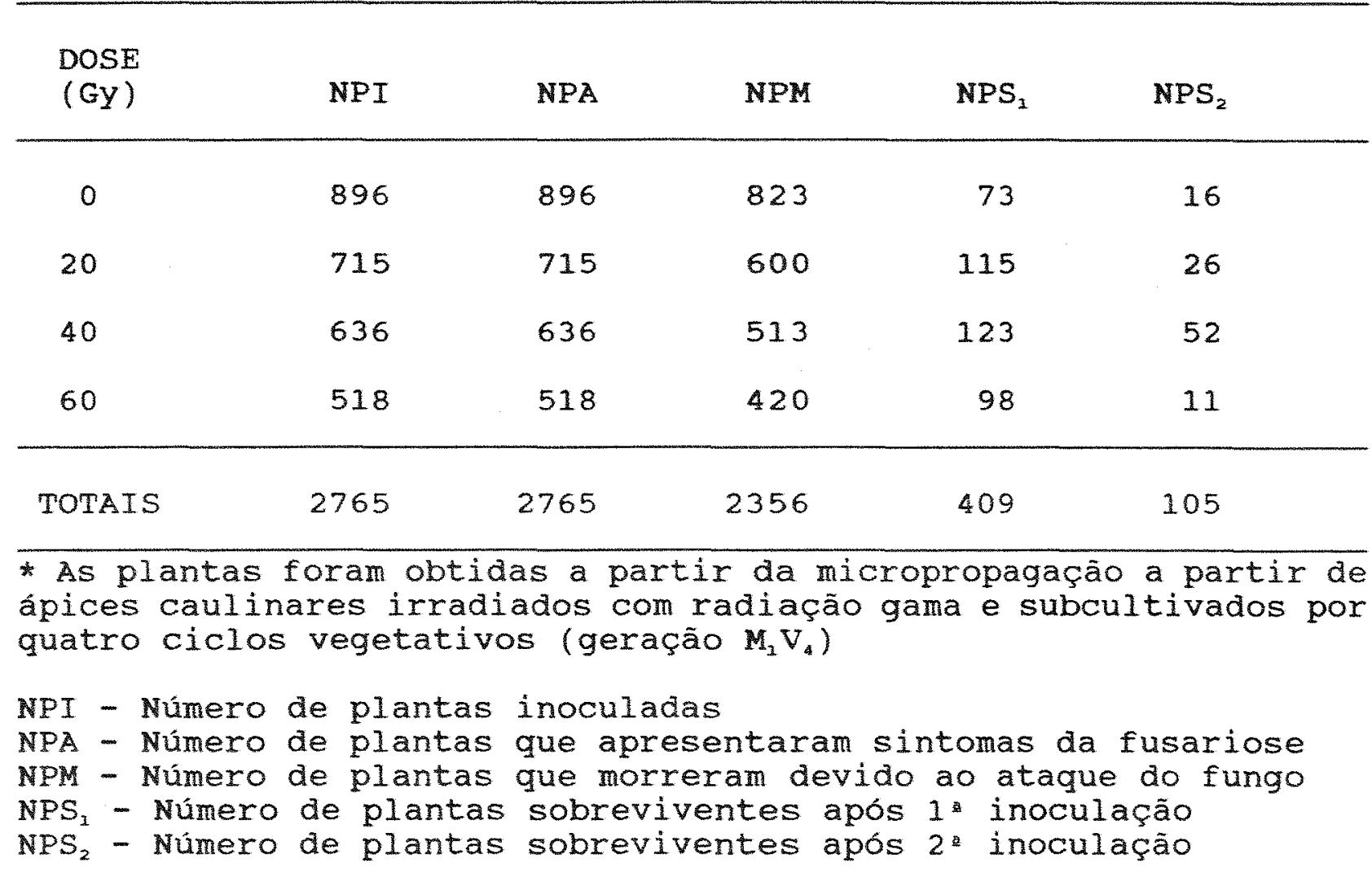


Estas plantas, apesar de sobreviverem após inoculação, como se observa na Tabela 11, também apresentaram sintomas e estes não diferiram quando em plantas originadas de ápices caulinares irradiados ou não irradiados. As plantas sobreviventes podem apresentar interesse, uma vez que possiveis setores mutados podem vir a se manifestar, através de brotações laterais mais tolerantes ou mesmo resistentes à Fusariose.

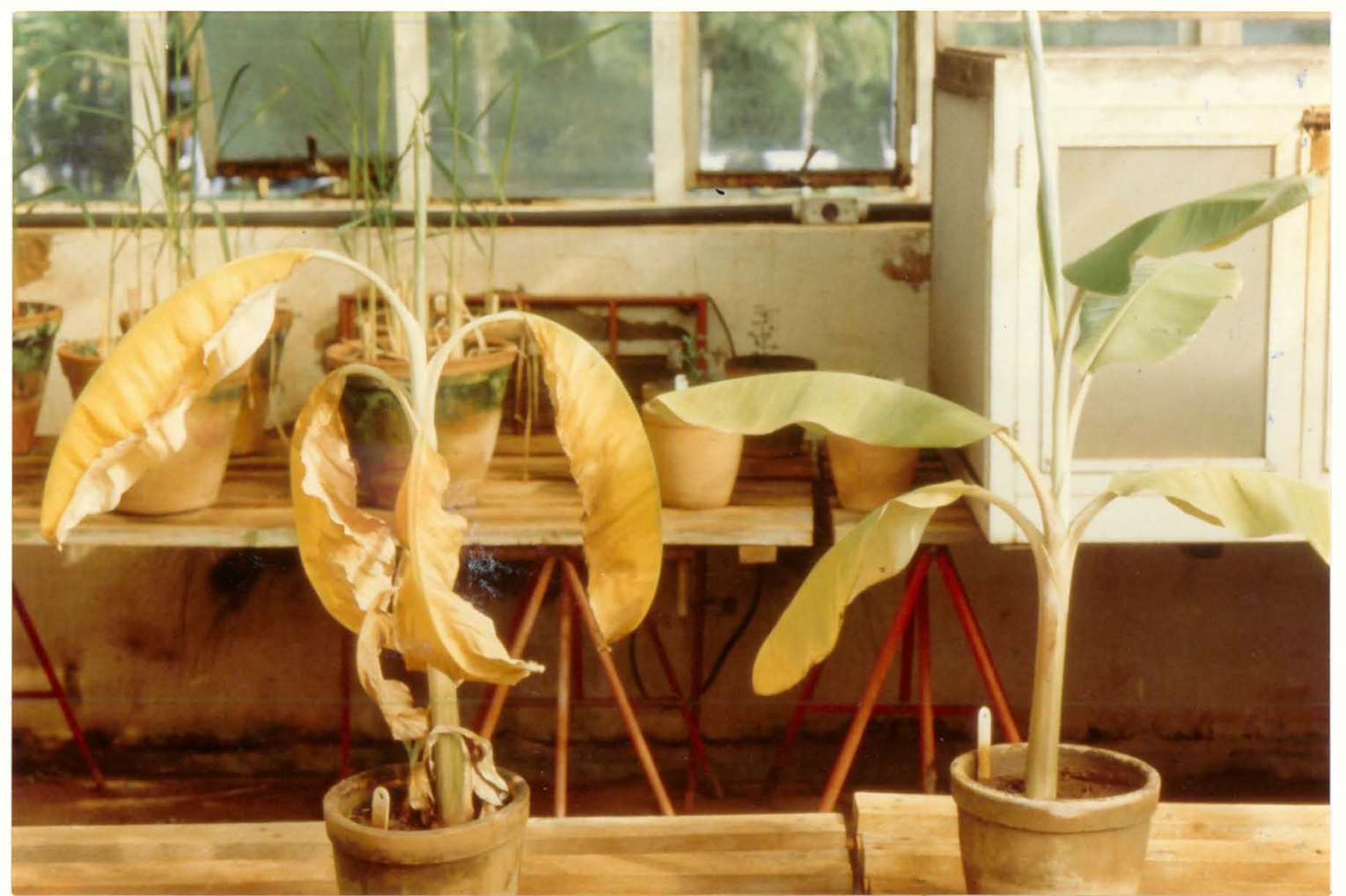

Figura 5 - Foto ilustrativa de plantas de bananeira cultivar Maçã (grupo $A A B$ ) com sintomas iniciais (à direita) e com sintomas mais avançados (à esquerda) da infestação com - Fusarium oxysporum f.sp. cubense, causador da Fusariose da bananeira. 
Os sintomas apresentados nas plantas jovens de bananeira em casa de vegetação corresponderam às indicações de MARTINEZ (1986) e MENDES et al. (1989), ocorrendo externamente o amarelecimento gradual e constante das folhas mais velhas em direção às mais novas, como ilustra a Figura 5 .

Normalmente em plantas de campo, esta doença provoca a quebra do peciolo foliar junto ao pseudocaule. Na presente pesquisa no entanto observou-se que isto não ocorreu de maneira pronunciada, devido ao tamanho reduzido das folhas das plantas em casa de vegetação.

As rachaduras das bainhas foliares na altura do colo da planta foram bastante pronunciadas, mostrando estarem, na maioria dos casos, relacionadas ao ataque do patógeno.

Internamente ocorreu escurescimento dos vasos condutores tornando a tonalidade branca dos rizomas sadios em levemente amarelo-acinzentados até a necrose total das áreas infectadas dos rizomas $e$ das bainhas foliares, adquirindo a coloração marrom escura. Após a infestação com o fungo, na maioria dos casos, a planta inoculada definhou até a morte, ou em outros, - meristema apical restabeleceu o seu crescimento através de uma rachadura no pseudocaule atacado.

A metodologia de seleção de plantas resistentes à Fusariose, realizada em casa de vegetação, mostrou-se satisfatória, porém existe a possibilidade de seleção in vitro das plantas às toxinas do patógeno. ILLG (1990) e outros autores, relataram que a 
seleção para resistência a doenças pode ser realizada in vitro e muitas vezes à nível celular. MENDES \& RODRIGUES (1991) notaram diferenças na resposta entre plântulas dos cultivares Maçã, Nanicão e Pisang Mass, quando inoculadas em meio líquido, contendo diversas concentrações de ácido fusárico e de filtrado contendo toxinas do patogeno causador da Fusariose.

Diversos autores relatam a existência de diferenças nas respostas das plantas com relação à susceptibilidade às doenças, dependendo do seu estágio de desenvolvimento. No presente trabalho a seleção foi realizada a nivel de casa de vegetação, porém recomenda-se a utilização de outras maneiras de seleção disponiveis, visando a seleção de plantas de bananeira resistentes à Fusariose.

As técnicas in vitro e em casa de vegetação podem apresentar vantagens em relação à seleção em campo, devido à economia de espaço e tempo. Há exemplos, entretanto, de plantas que apresentam resistência de campo e que são susceptiveis quando submetidas à inoculação em estagios iniciais de desenvolvimento.

4.7. Avaliação dos variantes fenotipicos obtidos

A observação dos variantes fenotípicos iniciou-se durante a quarta e última geração de propagação vegetativa in vitro, porém, estes foram observados com maior frequência em casa 
de vegetacão devido a maior facilidade de reconhecimento dos aspectos fenotipicos.

Tabela 12. Variações fenotípicas e respectivas frequências em bananeira "Maçã" (grupo AAB) micropropagada a partir de apices caulinares irradiados e subcultivados por quatro ciclos vegetativos.

DOSE

(GY) NPR PVVA PVVB PFE PFR PAPL PPP MD PANA TOT. FR(\%)

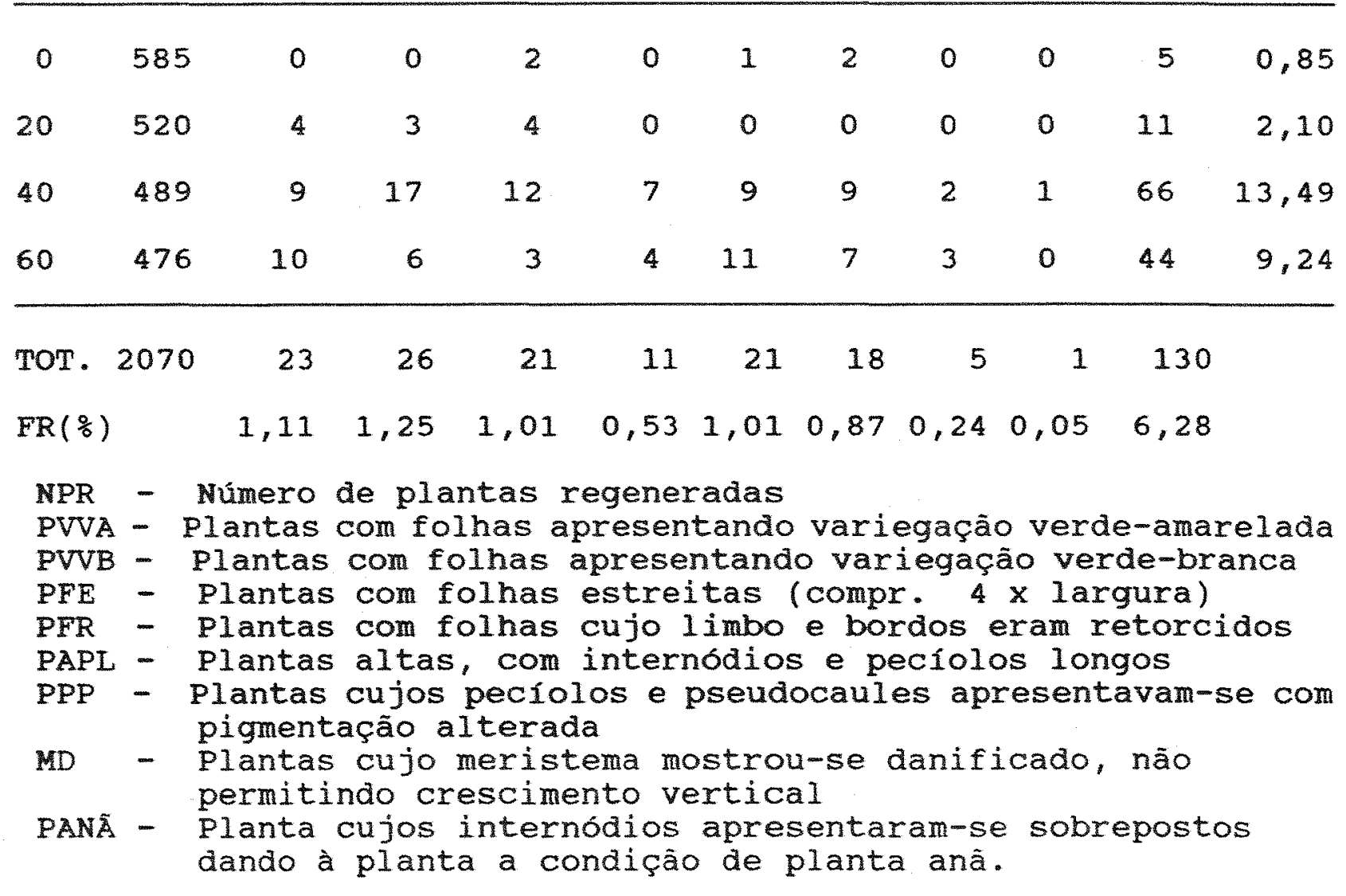

A Tabela 12 e $\circ$ APENDICE 18 mostram $\circ$ número de variantes obtidos no Experimento 10, em casa de vegetação (após o cultivo in vitro de ápices caulinares, de bananeira "Maçã", irradiados e não irradiados, por quatro gerações vegetativas). Como 
se observa, foram obtidas diversas plantas fenotipicamente distintas das plantas originais. Estas alteraçōes, de natureza genética ou epigenética, podem ter sido provocadas por variação somaclonal ou através da indução de mutação.

As plântulas de bananeira "Maçã" obtidas do cultivo in vitro não irradiadas (585), apresentaram diversidade com relação a largura de folhas, folhas estreitas (PFE, 2 plantas), planta alta com maior distancia entre internódios e maiores pecíolos (PAPL, 1 planta) e à maior pigmentação, com antocianina, do peciolo e pseudocaule (PPP, 2 plantas). Ao todo foram 0,85\% de variantes somaclonais, obtidos de ápices caulinares micropropagados por quatro gerações vegetativas.

Este percentual de variantes somaclonais poderia, no entanto, ser mais elevado se estas plantas fossem observadas em campo, em estágio adulto, uma vez que VUYLSTEKE et al. (1988) e (1990) observaram pela análise em campo que, 107 plantas de bananeira, obtidas do cultivar "AAB" subcultivadas in vitro ate a quarta geração, apresentaram $2,8 \%$ de variação somaclonal (folhas deformadas).

HWANG \& KO (1987) obtiveram frequências de variantes fenotípicos para um cultivar pertencente ao subgrupo cavendish, os quais foram obtidos após subcultivo de ápices meristemáticos in vitro. Ocorreram varíações de $0,4 \%$ a $1,44 \%$ para diversos variantes de estatura, formato de folha, cor do pseudocaule e alterações nas inflorescências. Ao todo foi observado $3 \%$ de variação em campo para este cultivar, os autores não indicaram o tempo de cultivo deste 
material in vitro. Os mesmos autores afirmam que existem diferenças nas frequências de variantes para diferentes genótipos.

A variação somaclonal pode ser utilizada para o melhoramento genético de Musa, mais especificamente para a obtenção de resistência a doenças como Fusariose (HWANG \&o, 1987) e Malde-Sigatoka (STOVER, 1987). Os primeiros autores citados obtiveram 6 variantes somaclonais de cultivar do subgrupo Cavendish resistentes à raça 4 da Fusariose, porém estes variantes, ainda em teste, parecem não apresentar boas caracteristicas agronômicas.

Para efeito de micropropagação, no entanto, estas alterações não são desejáveis, uma vez que visa-se uniformidade da qualidade do produto e na produção, e para a bananeira, segundo KRIKORIAN (1988a), são obtidos comercialmente algumas vezes, níveis de variação somaclonal acima do aceitável.

Pela observação de diversas referências, observa-se que o genótipo subcultivado in vitro pode favorecer o maior ou menor aparecimento de variantes somaclonais. REUVENI (1988), trabalhando com o cultivar willians pertencente ao subgrupo Cavendish, obteve diversos variantes somaclonais. A maioria deles, foram alterações para porte da planta (plantas anãs, 75\%) enquanto que as demais (25\%) apresentaram principalmente alterações de pigmentação das folhas, apresentando fenótipo semelhante ao mosaico provocado pelo ataque de vírus. Na presente pesquisa, no entanto, observou-se que para as condições utilizadas, o cultivar Maçã, até a quarta geração de multiplicação vegetativa in vitro não 
apresentou tais variantes, os quais somente apareceram com uso de raios gama.

As alterações encontradas, utilizando-se a radiação gama como agente mutagênico, apresentaram maior frequência, quando comparadas aos niveis de variação somaclonal encontrados. os efeitos, no entanto, foram mais pronunciados para as doses de 40 e $60 \mathrm{~Gy}$, como pode se observar na Tabela 12. Para a dose de 20 Gy foram encontradas $2,10 \%$ de variantes fenotipicos, na quarta geração de multiplicação vegetativa, sendo a maioria destas alteraçōes para clorofila foliar ( 7 plantas), entre as quais, plantas apresentando folhas com variegação verde e amarela (PVVA, 4 plantas) e plantas apresentando variegação verde e branca (PVVB, 3 plantas) e alterações para o formato das folhas, folhas estreitas (PFE, 4 plantas).

Para a dose de 40 Gy foi encontrada a frequência de variantes de $13,49 \%$, sendo que nesta dose foi possivel se encontrar - maior número de tipos de variantes. Os variantes fenotípicos para clorofila foliar (PVVA, 9 plantas e PVVB, 17 plantas) foram os mais frequêntes, seguidos dos variantes para largura de folha (PFE, 12 plantas), folha com o limbo foliar retorcido (PFR, 7 plantas), plantas altas com internódios e peciolos foliares longos (PAPL, 9 plantas), pigmentação intensa com antocianina do peciolo e pseudocaule (PPP, 9 plantas) e meristema danificado (MD, 2 plantas). Outra alteração encontrada na dose de 40 Gy foi uma planta de porte anão (PANÃ), representada pela Figura 6, e que por sua vez não foi encontrada em outras doses nem no controle. 


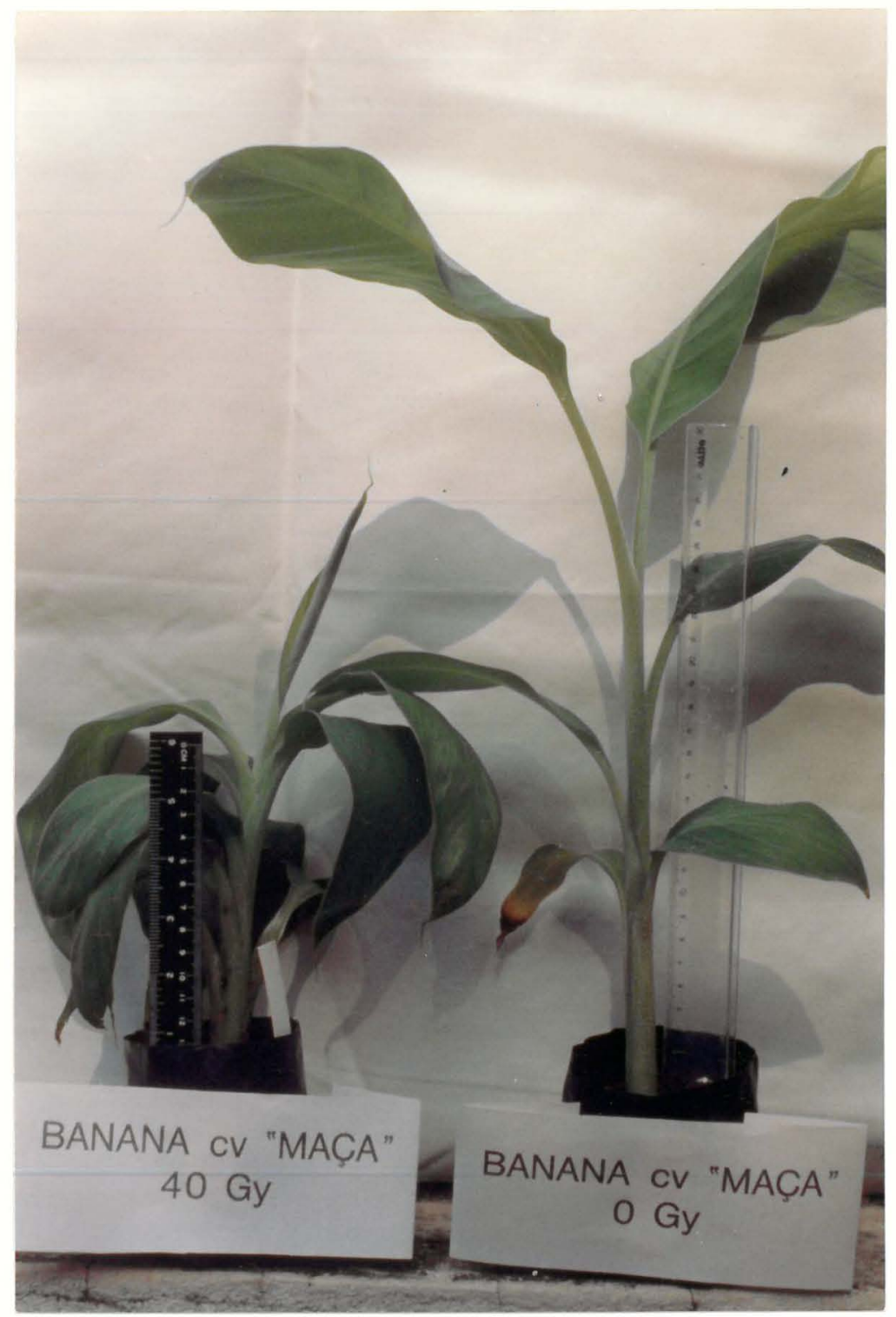

Figura 6 - Foto ilustrativa de plantas de bananeira cultivar Maçã (grupo $A A B$ ) com internódios curtos (planta anã), à esquerda, obtida a partir da irradiação com 40 Gy de raios gama, e planta obtida do controle com internódios longos (à direita). 
Este resultado corresponde ao obtido por NOVAK et al. (1990) quando obtiveram um mutante do cultivar Grand Naine, após o cultivo por quatro gerações vegetativas após irradiação dos ápices caulinares com a dose de 60 Gy, esta planta mutante foi denominada de $\mathrm{GN}-60$ e está sendo testada para a sua utilizaçao comercial.

Para a dose de 60 Gy foi encontrada a frequência de $9,24 \%$ de variantes fenotipicos em plantas, representados pela variação foliar (PVVA, 10 plantas), ilustrada pela Figura 7 , (e PVVB, 6 plantas), folhas estreitas (PFE, 3 plantas), folnas com - limbo foliar retorcido (PFR, 4 plantas), plantas altas com internódios e peciolos longos (PAPL, 11 plantas), e pigmentação dos pecíolos e pseudocaule com antocianina (PPP, 7 plantas) e plantas que não apresentaram crescimento vertical, provavelmente apresentando o meristema danificado (MD, 3 plantas).

Além destes tipos de alteraçöes foram encontradas ainda outras como alterações no formato e tamanho das folhas, no ângulo de inserção foliar junto ao pseudocaule, no tipo de desenvolvimento (mais lento, com pseudocaules de maior diâmetro ou mais rápido, com diâmetro menor), porém tais diferenças não foram quantificadas.

PEREA DALIOS \& NOVAK (1988) obtiveram diversos variantes fenotipicos, após o subcultivo por quatro gerações vegetativas de ápices caulinares irradiados, para diversos clones de Musa. 


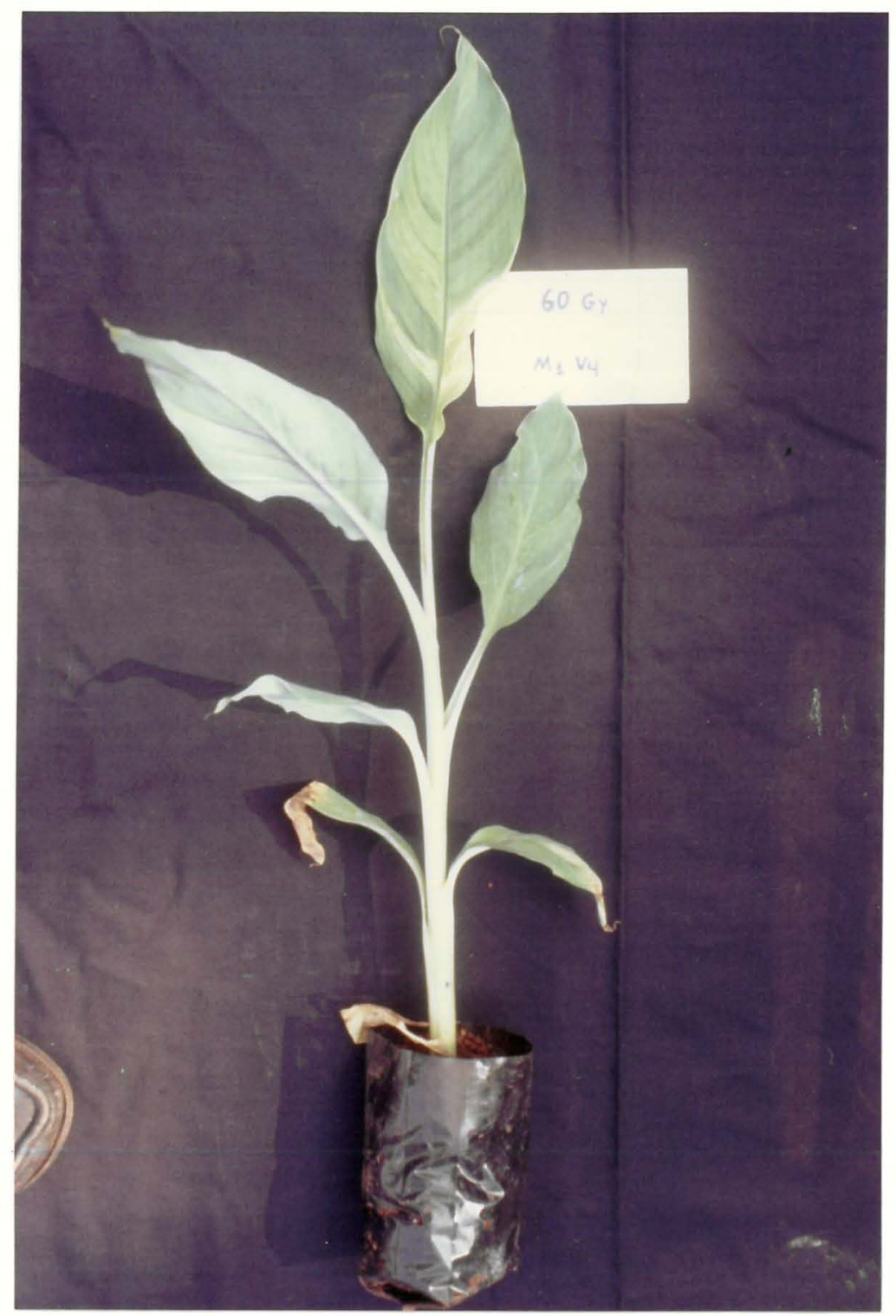

Figura 7 - Foto ilustrativa de planta de bananeira cultivar Maçã (grupo $\mathrm{AAB}$ ) na geração $\mathrm{M}_{2} \mathrm{~V}_{4}$, apresentando folhas variegadas nas cores verde e branca, obtida através da irradiação de ápices caulinares com raios gama na dose de $60 \mathrm{~Gy}$. 
Estes autores não citaram a frequência em que foram obtidas tais variações, mas os principais citados foram as plantas altas com internódios longos, plantas baixas de internódios curtos, plantas com folhas largas, formas irregulares para a lâmina foliar, perfilhamento sobre um único rizoma, mudanças na coloração foliar para antocianina e para variegação verde amarela e aparecimento precoce de flores e frutos. Destas alteracões apenas a úlima não foi observada no presente trabalho.

Com relação à estabilidade das alterações fenotipicas obtidas observou-se que a maioria das alterações de clorofila (PVVA e PVVB) mostraram-se reversiveis, indicando tratar-se na maioria dos casos, de setores mutados, portanto quimeras, que durante o crescimento das plantas tenderam a desaparecer.

Provavelmente os setores mutados, com menor teor de clorofila, apresentaram menor competitividade em relação aos tecidos não mutados, BROERTJES \& VAN HARTEN (1988) atestam que este tipo de competição intrassomática leva muitas vezes, à eliminação das células mutadas. Alguns dos variantes fenotípicos encontrados, no entanto, mantiveram-se estáveis até o momento, como o variante de porte anão (PANA), um variante de clorofila (PVDB), entre outros sem maior expressão.

SHEPHERD (1983) atribui as mutações somáticas espontaneas a diversificação dos cultivares comestiveis de bananeira (APENDICES 7 e 8), torna-se lógico pensar na ampliação da 
variabilidade desta cultura através da indução de mutação, uma vez que o melhoramento através de cruzamentos encontra certas dificuldađes, esta idéia também é defendida por BROERTJES \& VAN HARTEN (1988), KRIKORIAN \& CRONAUER (1984), CRONAUER-MITRA \& KRIKORIAN (1986), NOVAK et al. $(1986,1989$ e 1990) e NOVAK (1991). Pelos resultados do presente trabalho, pode-se constatar que a indução de mutação, através do uso de radiação gama, mostrou-se eficiente para a ampliação desta variabilidade. A principal dificuldade encontrada se refere a seleção dos mutantes obtidos, uma vez que nem todos são de fácil constatação, o que também é citado por SHEPHERD (1983) o qual lembra, que pequenas diferenças morfo e fisiológicas de interesse, inclusive resistência à doença, nem sempre são de fácil reconhecimento.

Para o melhoramento genético de Musa, segundo BROERTJES \& VAN HARTEN (1988) deseja-se plantas que combinem boa qualidade de frutos com resistência à doenças. Para o melhoramento genético do cultivar Maçã, no entanto, a resistência à fusariose é prioritária e a avaliação de outras caracteristicas de interesse agronômico pode apresentar interesse para o cultivo em áreas não contaminadas com o patógeno. Já para outros cultivares resistentes à Fusariose, a prioridade é a obtenção de plantas resistentes a outras moléstias, mutações para o porte anão, as quais podem minimizar o tombamento das plantas no campo pelo vento e a obtenção de plantas mais produtivas. 


\subsection{Indução da embriogênese somática}

o processo de indução de embriogênese somática em Musa spp., para os cultivares Maçã, Nanicão e para o clone GN-60, passou por 4 fases, a primeira constou da obtenção prévia de estruturas embriogênicas, a partir de segmentos de rizoma e pseudocaule, tendo sido obtidos inicialmente calos e estruturas globulares, os quais foram então cultivados em meio líquido para formação de novas estruturas e suspensões celulares. Ambas as culturas então foram transferidas para meio contendo citocinina para desenvolvimento e posterior germinação dos embrióides.

\subsubsection{Obtenção das estruturas embriogênicas}

o experimento 11 teve como finalidade a avaliação do regulador de crescimento Dicamba para a indução de estruturas embriogênicas, quando utilizado em diferentes concentrações, para os clones Maçã, GN-60 e Nanicão. Serviu também para a observação da oxidação nos explantes durante este processo, além das melhores dimensões e posições do rizoma e pseudocaule que responderam formando estruturas globulares e calos.

A Tabela 13 mostra o percentual médio de estruturas embriogênicas induzido em diversos cultivares de bananeira com a utilização de diversas concentrações do regulador de crescimento 
Dicamba. Os resultados confirmaram o obtido por NOVAK et al 1989, - meio com Dicamba mostrou-se favorável para a indução da embriogênese somática nos 2 cultivares testados (Maçã, Nanicão) e no clone GN-60. Ocorreram formações de estruturas embriogênicas (estruturas globulares e calos), quando em condições favoráveis, a partir do $15^{2}$ dia após inoculação dos explantes, atingindo o ponto máximo em torno de 45 dias. Ocorreu uma tendência para a oxidação dos calos obtidos após 45 dias.

Tabela 13. Percentual médio* de estruturas embriogênicas induzidas em diversos clones de bananeira com a utilização de diversas concentrações do regulador de crescimento Dicamba **

\begin{tabular}{|c|c|c|c|c|}
\hline \multirow[b]{2}{*}{ CLONES } & \multirow[b]{2}{*}{0} & \multicolumn{2}{|c|}{ Concentracão de } & $(\mathrm{mg} / 1)$ \\
\hline & & 2.0 & 3.5 & 6.63 \\
\hline & $\frac{\circ}{2}$ & $\%$ & $\%$ & $\%$ \\
\hline Macã & 0 & $14,31 \quad b$ & $25,96 \quad b$ & 84,31 a \\
\hline $\mathrm{GN}-60$ & 0 & $36,28 \quad b$ & 83,55 a & $7,91 \mathrm{~b}$ \\
\hline Nanicão & 0 & $77,59 \mathrm{a}$ & $41,94 \quad b$ & $25,43 \quad b$ \\
\hline
\end{tabular}

A ausência de regulador de crescimento para todos os cultivares induziu o crescimento de raiz e de gemas apicais ou axilares. Tais respostas não ocorreram para as demais concentrações 2,$0 ; 3,5 ; 6,63 \mathrm{mg} / 1$, o que indicou que o regulador de crescimento Dicamba inibiu tais proliferações. 
Ocorreram diferenças significativas nas respostas para as diferentes concentraçōes do regulador de crescimento utilizadas para cada cultivar. A concentração de 2,0 ing de Dicamba mostrou-se a mais favorável para o cultivar Nanicão, onde ocorreu a formação de estruturas embriogênicas em 77,59\% dos explantes utilizados.

A concentração de $3,5 \mathrm{mg}$ foi melhor para $0 \mathrm{GN}-60$ onde ocorreu a formação das estruturas em $83,55 \%$ dos explantes, já a concentração de $6,63 \mathrm{mg}$ foi melhor para o cultivar Maçã, onde 84,31\% dos explantes apresentaram a formação destas estruturas.

En trabalho de NOVAK et al. (1989), do qual foi adaptada a metodologia para este trabalho, foram utilizadas diversas concentrações deste regulador de crescimento Dicamba, para 4 genótipos de Musa e observou-se que concentrações deste regulador acima de $6,63 \mathrm{mg} / 1$ provocaram o escurescimento dos explantes e exudação de compostos fenólicos. Resposta semelhante foi observada no presente trabalho, pois para alguns cultivares mesmo a concentração de $6,63 \mathrm{mg} / 1$ foi capaz de induzir escurescimento e exudação de fenóis.

Nesta pesquisa também foi observado que cada cultivar respondeu formando maior ou menor percentual de estruturas globulares e calos. Para o cultivar Maçã (grupo AAB) e Nanicão (grupo AAA) ocorreu maior formação de estruturas globulares, as quais estão representadas pela Figura 8 , seguida da formação de calos semi-compactos e opacos. 


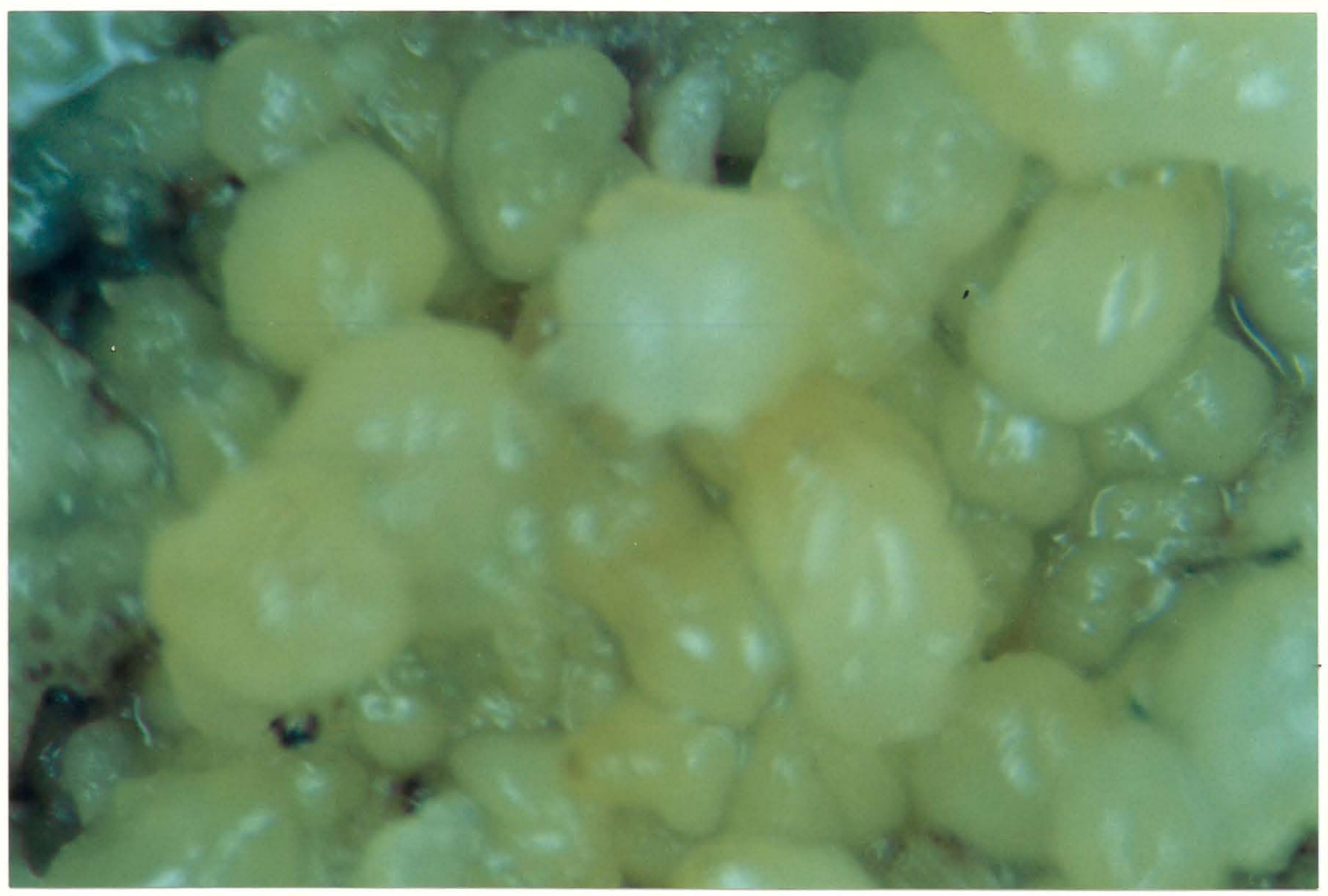

Figura 8 - Foto ilustrativa de estruturas globulares induzidas em tecidos do rizoma e pseudocaule de bananeira através do uso do regulador de crescimento Dicamba (16x).

Para o clone $\mathrm{GN}-60$, como ilustrado na Figura 9, ocorreu além da formação destes dois tipos de estruturas, a formação de calos menos compactos e translúcidos os quais foram mais frequentes. CHEN et al. (1987) trabalhando com diversos 
genótipos de alfafa observaram que os meios de cultivo e concentração de regulador de crescimento variaram de um genótipo para outro. Tal diferença de resposta para diferentes cultivares de bananeira também foi observada por NOVAK et al. (1989).

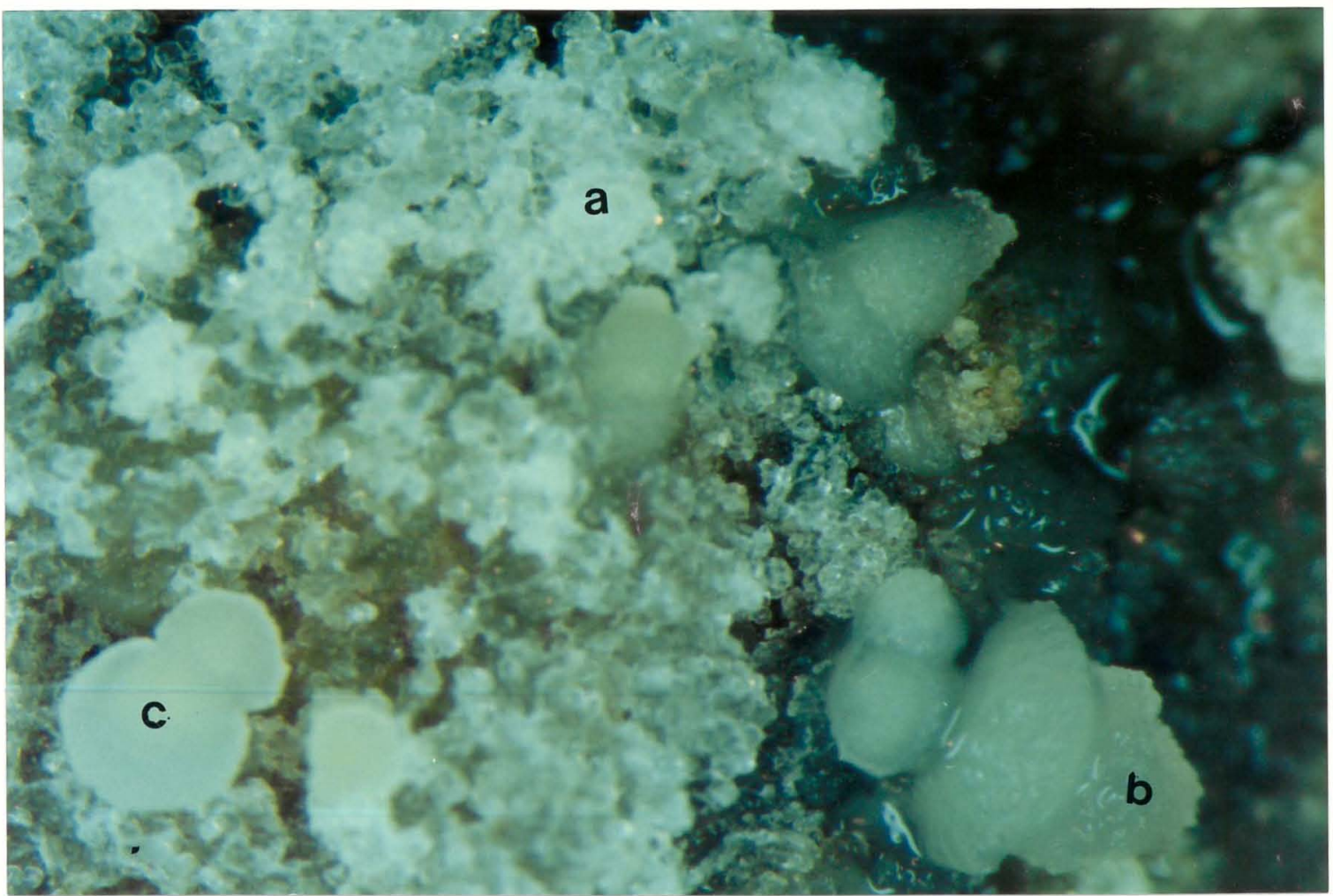

Figura 9 - Foto ilustrativa de calos translúcidos (a), opacos (b) e estruturas globulares (c) induzidos em tecidos do rizoma e pseudocaule de bananeira através do uso do regulador de crescimento Dicamba (12x). 
Foi também avaliada a oxidação dos explantes dos três cultivares utilizados no presente trabalho. A oxidação ocorreu em praticamente todos os casos em maior ou menor intensidade. Notou-se que concentrações inferiores ou superiores as adequadas para a formação das estruturas embriogênicas induziram oxidação mais acentuada nos explantes utilizados.

A Tabela 14 mostra o percentual médio de oxidação dos explantes de diversos cultivares de bananeira com a utilização de Dicamba. A ausência do regulador de crescimento provocou elevados percentuais de axidações, as quais portanto não estiveram diretamente relacionadas à presença do Dicamba.

Tabela 14. Percentual médio* de oxidação dos explantes de diversos clones de bananeira com a utilização de Dicamba. **

\begin{tabular}{|c|c|c|c|c|c|}
\hline \multirow[b]{2}{*}{ CLONE } & \multicolumn{5}{|c|}{ Concentração de Dicamba (mg/1) } \\
\hline & 0 & 2.0 & 3.5 & 6.63 & \\
\hline & 을 & $\%$ & $\frac{9}{6}$ & 䋧 & \\
\hline Macã & 49,86 a & 23,75 a & $39,95 \mathrm{a}$ & 20,84 & a \\
\hline$G N-60$ & 67,74 a & 41,52 ab & $18,35 \mathrm{ab}$ & 76,56 & $\mathrm{~b}$ \\
\hline Nanicão & 56,52 a & $14,33 \quad b$ & $28,73 \mathrm{~b}$ & 41,81 & $\mathbf{b}$ \\
\hline
\end{tabular}

Como pode se notar, comparando as Tabelas 13 e 14 , as concentrações que provocaram maior produção de estruturas embriogênicas para cada cultivar, foram também aquelas onde os 
explantes apresentaram menores oxidações. Para o cultivar Maçã, a concentração de $6,63 \mathrm{mg} / 1$ de Dicamba provocou um percentual de oxidação de 20,84 , o menor indice apresentado por este cultivar, enquanto que para o clone $G N-60$ o menor percentual de oxidação foi observado na concentração de $3,5 \mathrm{mg} / 1$, com $18,35 \%$ de oxidação, já - cultivar Nanicão apresentou menor oxidação con 2,0 mg/1 de Dicamba $(14,33 \%)$

As dimensões dos explantes utilizados variaram de 6,5 a $9,0 \mathrm{~mm}$ de diâmetro e de 1,5 a $2,0 \mathrm{~mm}$ de espessura, sendo que foram obtidos em média 6 explantes por plântula utilizada inicialmente. Notou-se que os explantes de maior diâmetro tenderam a apresentar melhores respostas que os menores, sendo que os menores tenderam a apresentar maiores níveis de oxidação devido à ação do regulador de crescimento sobre os tecidos.

As posiçôes de rizoma e pseudocaule que melhor responderam ao estimulo à formação das estruturas embriogênicas também foram avaliadas. A Tabela 15 apresenta a posição média dos explantes que apresentaram melhor resposta à diversas concentrações de Dicamba. A porção que respondeu melhor, formando mais estruturas embriogênicas, foi aquela situada entre o rizoma e as bainhas foliares, correspondendo à porção mediana utilizada.

Os explantes uma vez numerados da base para o ápice, como ilustrado pela Figura 3, foram avaliados quanto a maior ou menor formação das estruturas embriogênicas. As posições constituídas apenas de tecidos do rizoma não se mostraram adequadas, não 
produzindo resposta favorável. A partir da posição 3, logo abaixo da posição do ápice meristemático, foi a posição mais baixa de explante a responder favoravelmente, a seguir vieram as posições 4 englobando o ápice meristemático e 5 logo acima do ápice meristemático.

Para o cultivar Maçã as porçōes que melhor responderam à indução da embriogênese somática situaram-se entre as posições 3 e 6 , enquanto que para o clone $G N-60$ as melhores respostas situaram-se entre 4 e 6 e para o Nanicão entre 4 e 5 , como pode ser observado pela tabela 15.

As posições abaixo e acima destas médias observadas tenderam a não formar estruturas embriogênicas e a apresentar maiores percentuais de oxidação.

Tabela 15. Posição média dos explantes que apresentaram melhor resposta às diversas concentrações de Dicamba. **

Concentração de Dicamba (mg/1)
CLONE
2.0
3.5
6.63

$\begin{array}{llll}\text { Macã } & 6,01 \mathrm{a} & 4,58 \mathrm{ab} & 3,58 \mathrm{~b} \\ \text { GN-60 } & 5,67 \mathrm{a} & 5,70 \mathrm{a} & 4,85 \mathrm{a} \\ \text { Nanicão } & 4,82 \mathrm{a} & 4,93 \mathrm{a} & 4,25 \mathrm{a}\end{array}$

* Médias seguidas de letras iguais não diferem significativamente entre si, no sentido horizontal, pelo Teste de Tukey 5\% (CV.12.5\%) * Avaliação 45 dias após inoculação.

Como ponto comum entre os cultivares foi observado que os explantes localizados logo abaixo ou logo acima do meristema 
apical foram os que formaram maiores percentuais de estruturas embriogênicas.

Segundo AMMIRATO (1983) nas gramineas (monocotiledôneas) a embriogênese somatica se verifica em poucos tecidos, especificamente nos ápices de crescimento ativo. Isto talvez explique o verificado para a embriogênese de Musa, a qual tem sido conseguida ou em tecidos florais ou tecidos próximos ao ápice meristemático, entre o rizoma e pseudocaule. Mas assim como NoVAK et al 1989, no presente trabalho observou-se que o explante contendo o meristema apical não foi o mais adequado para a indução da embriogênese somática, devìo à dominância apical, a qual induz a recuperação da parte aérea da planta inicial, em detrimento da formação de estruturas embriogênicas.

Com a finalidade de se verificar a influência da concentração de sacarose na indução das estruturas embriogênicas, realizou-se o Experimento 12 fixando-se a concentração de Dicamba em $6,63 \mathrm{mg} / 1$, e variando-se o percentual de sacarose em 2 e $4 \%$. A Tabela 16 mostra o percentual médio de formação de calos e estruturas globulares à concentração de $6.63 \mathrm{mg}$ de Dicamba, com $2 \%$ e 4\% de sacarose.

Em cultivo houve formação de calos brancos translücidos menos compactos, calos mais compactos de coloração creme e estruturas globulares, os quais foram retirados com o auxilio de bisturi ou pinça, sem dificuldade. 
Pode-se observar pelos resultados apresentados, que ocorreu maior estímulo à formação de estruturas embriogênicas (calos e estruturas globulares) para os cultivares Maçã e Nanicão, quando o meio era mais pobre em sacarose (2\%) e para o clone GN-60 quando o meio de cultura era mais rico neste componente (4\%). Observa-se ainda na Tabela 16 que para a concentração de $2 \%$ de sacarose os cultivares Maçã e Nanicão formaram maior percentual de estruturas globulares e menor percentual de calos, enquanto que para o clone $\mathrm{GN}-60$ houve tendência para uma produção semelhante para ambos os tipos.

Tabela 16. Percentual médio de formação de calos e pró-embrióides à concentração de $6.63 \mathrm{mg}$ de Dicamba, com $2 \%$ e $4 \%$ sacarose.

Sacarose (\%)

2

$\frac{\text { CLONE Calos }}{(\%)}$

Maçã $\quad 1,73$

$\mathrm{GN}-60$

10,89

Nanicão 16,07
(\%)

51,72

9,90

35,71
(\%)

16,67

4,17

52,50

27,50

3,33

3,33

Para a concentração de $4 \%$ de sacarose houve maior indução de calos tanto para o cultivar Maçã, quanto para o clone GN-60, e menor formação de estruturas globulares. Já o cultivar 
Nanicão produziu o mesmo percentual de calos e estruturas globuIares.

Estes resultados confirmam indicação de vários autores, entre os quais SCHULTHEIS et al. (1990), quando relatam que o tipo e a concentração de carboidrato podem afetar a indução das estruturas embriogênicas. Provavelmente isto se deve ao maior ou menor fornecimento de energia aos tecidos e à alteração da pressão osmótica do meio de cultura. Os mesmos autores, ainda afirmam que estes fatores podem influir ainda na maturação dos embriōes somáticos, bem como influir na germinação e formação subsequente de plantas.

\subsubsection{Obtenção Desenvolvi dos embribides}

Aa estruturas globulares uma vez cultivadas em meio 11 quido sob elevada agitação produziram novas estruturas globulares, as quais apresentarem certo desenvolvimento. Tais culturas permitiram também a obtenção de suspensões celulares, tal aptidão também foi observada por PEREA DALLOS NOVAK (1988) e NOVAK et al. (1989). Já os calos obtidos mostraram diferenças ao serem cultivados em meio líquido, os mais compactos de coloração creme produziram boa suspensão celular, enquanto que os calos brancos translúcidos não apresentaram boa capacidade de divisão, não formando suspensões concentradas de células. 
Os embrióides obtidos a partir das estruturas globulares, após atingirem de 1 - $2 \mathrm{~mm}$ foram postos para germinar em meio contendo zeatina e iniciaram processo germinativo, porém emitiram apenas radicelas.

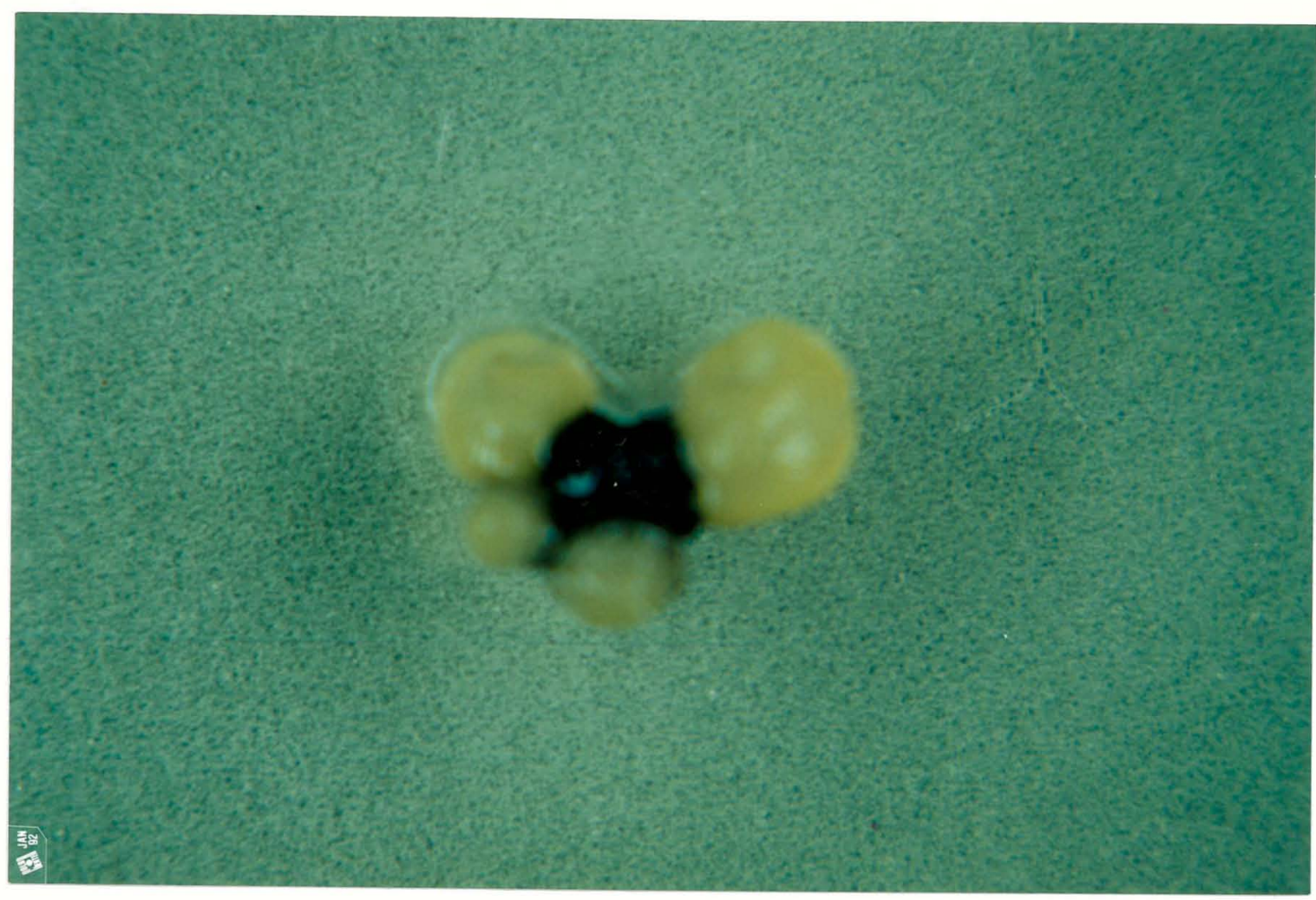

Figura 10 - Foto ilustrativa de embriões somáticos de bananeira em fase de desenvolvimento (12x). 
A Figura 10 ilustra embrióes somáticos de bananeira em fase de desenvolvimento, enquanto que a Tabela 17 mostra o percentual médio de embrioides verdes, oxidados e que formaram raiz em meio de germinação com zeatina.

Tabela 17. Percentual médio de embrióides verdes, oxidados e que formaram raiz em meio de germinação com Zeatina *

\begin{tabular}{cccc}
\hline CULTIVAR & $\begin{array}{c}\text { VERDES } \\
(\%)\end{array}$ & $\begin{array}{c}\text { OXIDAção } \\
(\%)\end{array}$ & $\begin{array}{c}\text { COM RAIZ } \\
(\%)\end{array}$ \\
\hline Maçã & 74,21 & 25,79 & 26,56 \\
GN-60 & 31,03 & 68,97 & 1,34 \\
Nanicão & 50,12 & 49,88 & 17,11 \\
\hline
\end{tabular}

Avaliação 15 dias após inoculação.

As respostas obtidas variaram para os clones testados, o cultivar Maçã apresentou raizes em $26,56 \%$ dos embrióides, o Nanicão em $17,11 \%$ e 0 clone GN-60 apresentou uma menor emissão de radicelas $(1,34 \%)$. As estruturas que apresentaram a emissão de raizes raramente apresentaram simultaneamente a emissão de parte aérea, e quando isto ocorreu, a parte aérea originada não se desenvolveu satisfatoriamente. o restante das estruturas permaneceram globulares sem emissão de raíes.

Estas estruturas tanto as que enraizaram, quanto as que permaneceram globulares apresentaram uma alteração de coloração em vários casos os embrióides que possuím a princípio a coloração branco-creme passaram a exibir a coloração verde, este processo 
também apresentou diferenças entre os clones testados, o cultivar Maçã apresentou $74,21 \%$ de estruturas verdes, contra $50,12 \%$ do Nanicão e $31,03 \%$ do clone $\mathrm{GN}-60$.

Os clones que apresentaram maior percentual de estruturas verdes foram os que apresentaram menor percentual de oxidação, enquanto que o contrário também é valido.

A utilização do meio de dupla fase (meio sólido com a adição de carvão ativado coberto com meio líquido sem antioxidante) parece ter sido importante para a diminuição da oxidação das estruturas, mas não resolveu totalmente o problema, talvez a utilização de outros tipos de antioxidantes pudesse resolver 0 problema.

Os trabalhos com embriogênese somática em bananeira são ainda poucos e recentes, segundo BAKRY (1988). Este autor comenta que as metodologias são complexas, e variam de um cultivar para outro. Têm-se obtido resultados positivos com espécies selvagens, produtoras de sementes, através de embriōes zigóticos jovens, é o caso de CRONAUER-MITRA \& RRIKORIAN (1988b) e ESCALAN \& TEISSON (1989), mas tais metodologias não podem ser aplicadas para cultivares estéreis.

DHED'Á et al. (1991) obtiveram cultura de suspensão celular a partir de estruturas globulares induzidas em cultura de meristemas, utilizando $2,4-D$ e luM de zeatina, o cultivo em meio sem reguladores de crescimento promoveu o desenvolvimento dos embrióides, os quais foram maturados e germinaram numa taxa de 10 14,4\%, em meio contendo citocinina. 
PEREA DALLOS \& NOVAK (1988) e NOVAK et al (1989) induziram a formação de calos embriogênicos em bananeira através do regulador de crescimento Dicamba e citam que o passo mais difícil foi a conversão dos embriões somáticos em plantas. Citaram que não obtiveram plântulas inicialmente das estruturas bipolares originadas das estruturas embriogênicas.

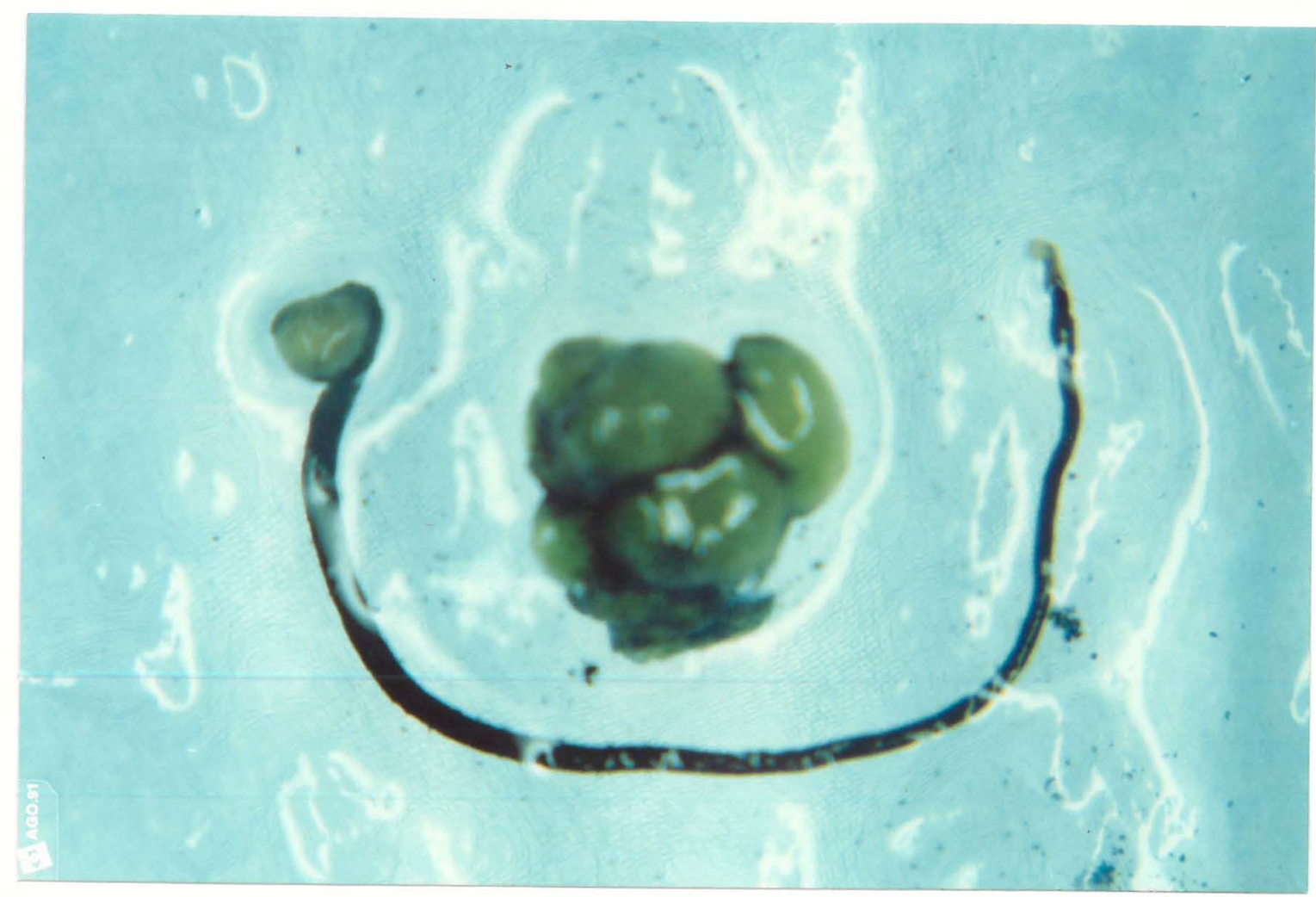

Figura 11 - Foto ilustrativa de embriões somáticos de bananeira apresentando germinação imperfeita, com ausência de emissão de parte aérea (12x). 
Estes mesmos autores confirmaram através de estudos histológicos a origem das células embriogênicas, independentes do tecido materno, das quais se desenvolveram os embriões somáticos em estruturas bipolares, dos quais obtiveram aproximadamente $200-300$ embrióes somaticos para cada $100 \mathrm{ml}$ de suspensão celular inicial.

No presente trabalho não foram regeneradas plântulas das estruturas bipolares obtidas, as quais apresentaram emissão de raiz durante a germinação mas não emitiram parte aérea (Figura 11), talvez devido a utilização de um número reduzido de amostras, uma vez que a eficiência do processo observada pelos últimos autores citados, foi baixa.

\title{
4.9. Cultivo de células e obtenção de protoplastos
}

\begin{abstract}
As estruturas embriogênicas obtidas lcalos e estruturas globulares) quando cultivadas sob elevada agitação de 80-120 rpm apresentaram-se como boa fonte de produção de suspensões celulares. Com relação aos dois tipos de calos obtidos lopacos e translúcidos), os últimos mostraram-se inadequados uma vez que apresentaram-se mais túrgidos quando em cultivo em meio liquido, e as células possuiram menor habilidade de divisão. Já as mais opacas apresentaram boa capacidade de divisão. As estruturas globulares obtidas também produziram suspensões celulares adequadas. As célu-
\end{abstract}


las inicialmente obtidas apresentaram-se bastante desuniformes (Figura 12).

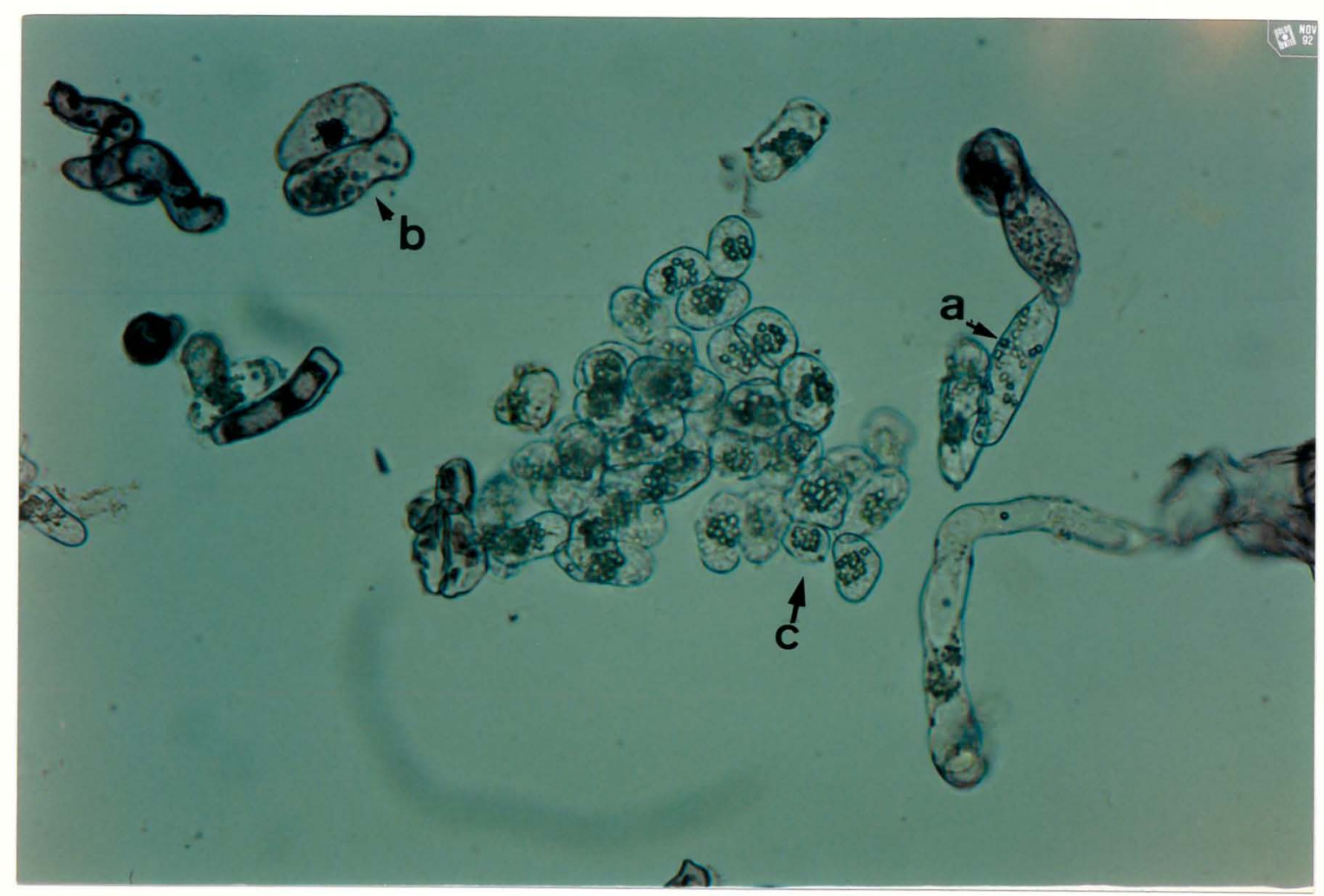

Figura 12 - Foto ilustrativa de suspensão celular com células desuniformes. Células túrgidas (a), células túrgidas oxidadas (b) e células adequadas para o cultivo (c) (200x).

\section{KRIKORIAN \& SCOTT (1990) obtiveram suspensões} celulares a partir de calo e também notaram um grande número de células já diferenciadas, as quais apresentavam pouca capacidade de divisão. Assim como constatado por estes autores, no presente 
trabalho observou-se que trocas frequentes (semanais) resultaram em culturas mais uniformes (Figura 13).

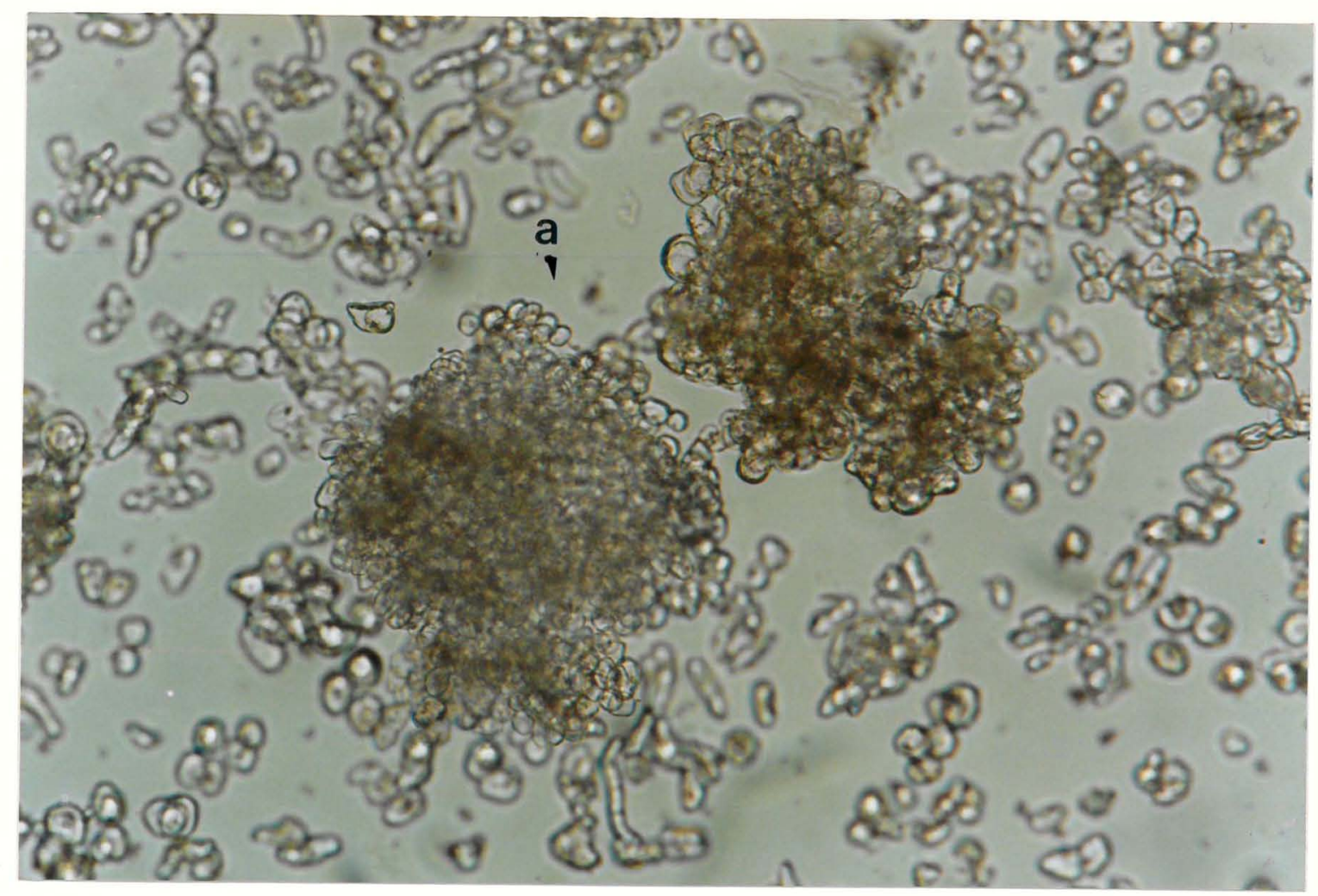

Figura 13 - Foto ilustrativa de suspensão celular com células uniformes, adequadas para o cultivo (200x).

Segundo KRIKORIAN \& SCOTT (1990) suspensões celulares têm sido estabelecidas para um número limitado de clones, principalmente os pertencentes ao grupos AA, grupo AAA (nesta pesquisa representado pelos clones $G N-60$, Nanica e Nanicão) ou $A B B$, 
enquanto que resultados positivos em $A B$ (no presente trabalno representado pelo cultivar Maçã) são ainda raros.

- atraso nas trocas ocasionaram células túrgidas e com baixa capacidade de divisão, além do fato de apresentarem maiores taxas de oxidações. Outro fator observado foi a quantidade de meio liquido utilizada na suspensão, esta não deve exceder muito - dobro do volume celular em cultivo, uma vez que isto induziu a formação de células túrgidas.

Poucos autores têm relatado isolamento de protoplastos de Musa de maneira bem sucedida (NovAK (1991). Estes autores ressaltam que a obtenção de protoplastos representa potencialmente uma valiosa ferramenta para trabalhos futuros envolvendo engenharia genética.

Vários autores, entre os quais GAMBORG et al. (1981), recomendam a utilização de calo ou suspensão celular para - isolamento de protoplastos. No presente trabalho, utilizou-se as suspensões celulares, obtidas a partir de estruturas embriogênicas (calos e estruturas globulares) para o isolamento de protoplastos de bananeira cultivares Maçã e Nanica.

Foi utilizada metodologia modificada de KRIKORIAN et al. (1988b), onde suspensões contendo células homogêneas, foram tratadas com soluçào de enzimas descrita por estes autores, os quais trabalhando com folhas de Musa obtidas em casa de vegetação, 
obtiveram um número de protoplastos que julgaram satisfatorio, apos algumas alterações na concentração de pectinase.

No presente trabalho, foi utilizada uma adaptação desta metodologia, trabalhou-se com aliquotas de suspensão celular na mesma proporção da solução de enzimas, o que pode ter diminuído a eficiencia da atividade enzimática. Não foi possivel o isolamento de protoplastos durante 12 horas de observação.

Este mesmo procedimento anterior foi adotado porém com solução de enzimas proposta por NovAK et al. (1992), os quais utilizando suspensões celulares, obtidas a partir de estruturas embriogênicas obtiveram um número elevado de protoplastos. Nesta pesquisa também foram obtidos resultados satisfatorios atraves desta metodologia, sendo que os protoplastos (Figura 14) começaram a ser observados após 4 horas e atingiram uma elevada concentração entre 6 e 8 horas de tratamento enzimático.

Utilizou-se aliquotas de suspensão celular na mesma proporção da solução de enzimas, o que provavelmente diminuíu a atividade enzimática, de maneira que foi possivel a observação de protoplastos até 24 horas após o inicio do tratamento, sem que houvesse um rompimento pronunciado da membrana celular.

Para confirmação dos protoplastos em observação, sob microscópio invertido, foi diminuida a pressão osmótica através de diluição em água. Este procedimento provocou o rompimento dos protoplastos. 


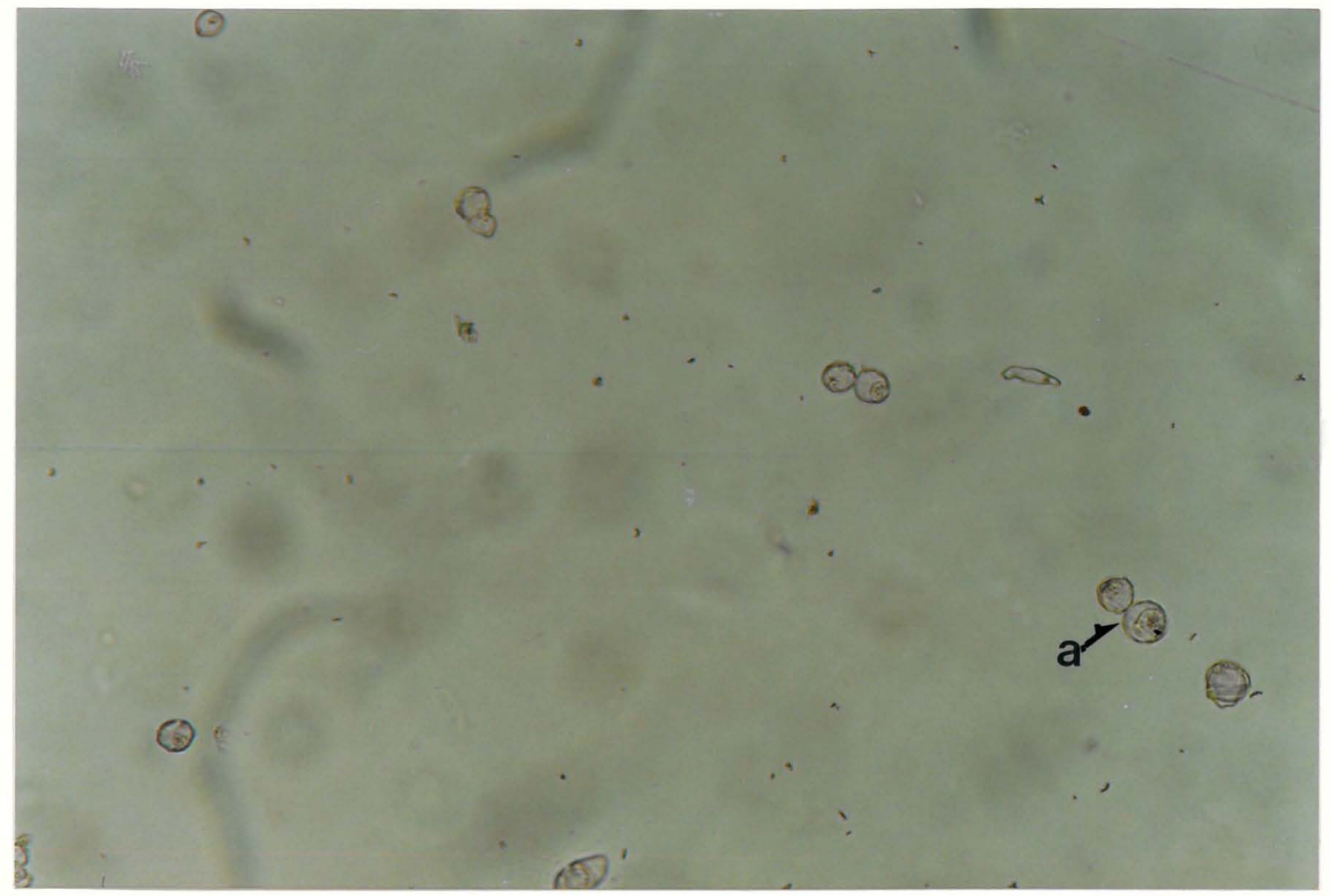

Figura 14 - Foto ilustrativa do isolamento de protoplastos de bananeira a partir de suspensão celular (200x).

os resultados obtidos durante o isolamento de protoplastos foi satisfatório, porém ainda podem ser melhorados. Recomenda-se para o caso de extração de protoplastos a utilização de precipitados da suspensão célular, obtidos através de centrifugação, para evitar a diluição das enzimas. Caso se deseje, como no presente trabalho, utilizar alíquota da suspensão celular, deve-se elevar a proporção de solução de enzimas aplicada. 


\subsection{Consideraços finais e perspectivas futuras}

A utilização da biotecnologia para Musa tem progredido muito nos últimos anos, muitos dos obstáculos encontrados para o melhoramento genético desta cultura poderão ser superados em breve.

Técnicas de cultura de ápices caulinares e micropropagação de genótipos produtivos de bananeiras e plátanos estão sendo utilizadas comercialmente, possibilitando maior uniformização da qualidade da produção e evitando a propagação de doenças e pragas através de mudas contaminadas.

Através da cultura de meristemas em meio de crescimento mínimo, pode-se realizar a conservação de germoplasma das espécies selvagens e dos cultivares de Musa. Assim como em meios indutores de brotaçōes intensas, pode-se gerar variabilidade somaclonal a qual poderá ser direcionada para trabalhos de melhoramento.

A embriogênese somática para estas culturas, sendo um sistema capaz de originar novas plantas a partir de uma ou poucas células, promete surgir como uma nova forma de indução de variabilidade, seja pela variação somaclonal provavelmente inerente ao processo, seja pela associação com técnicas de indução de mutações através de agentes físicos ou químicos.

Trabalhos visando a indução de mutação em bananeiras e plátanos, vem sendo realizados sobre explantes contendo tecidos meristemáticos in vivo, através do uso de radiação gama, e in vitro 
através de mutagênicos físicos e químicos. NovAK et al, 1990 obtiveram um mutante de porte anão a partir do cultivar Grand Naine, o qual encontra-se em testes para produção comercial.

Una vez bem estabelecida a metodologia para a obtenção de embrióes somáticos de Musa a partir de celulas únicas, os métodos de melhoramento atraves da fusão de protoplastos ganharão um grande impulso, podendo introduzir caracteristicas desejáveis, como resistência à doença, em genótipos de boa qualidade produtiva. Esta técnica representa potencialmente uma valiosa ferramenta para estudos de fisiologia e poderá futuramente ser muito útil em trabalhos de engenharia genética.

Até o momento, as técnicas de melhoramento convencionais, através de cruzamentos, têm sido de pouca utilidade para os cultivares triploides de bananeiras e platanos, devido à baixa produção de sementes viáveis ligada à elevada esterilidade destas culturas. Espera-se, no entanto, que com o auxilio das técnicas de biotecnologia muitas das barreiras encontradas pelo melnoramento clássico, possam ser superadas.

A Figura 15 mostra a sequência dos trabalhos realizados na presente pesquisa, onde a partir de plantas de genótipo superior (1), foram extraidos meristemas de ápices vegetativos e florais $\left(2 \mathrm{e} 2^{\prime}\right)$, os quais foram estabelecidos em meio de cultura apropriados para o desenvolvimento e indução de novos brotos $\left(3\right.$ e $\left.3^{\prime}\right)$. 


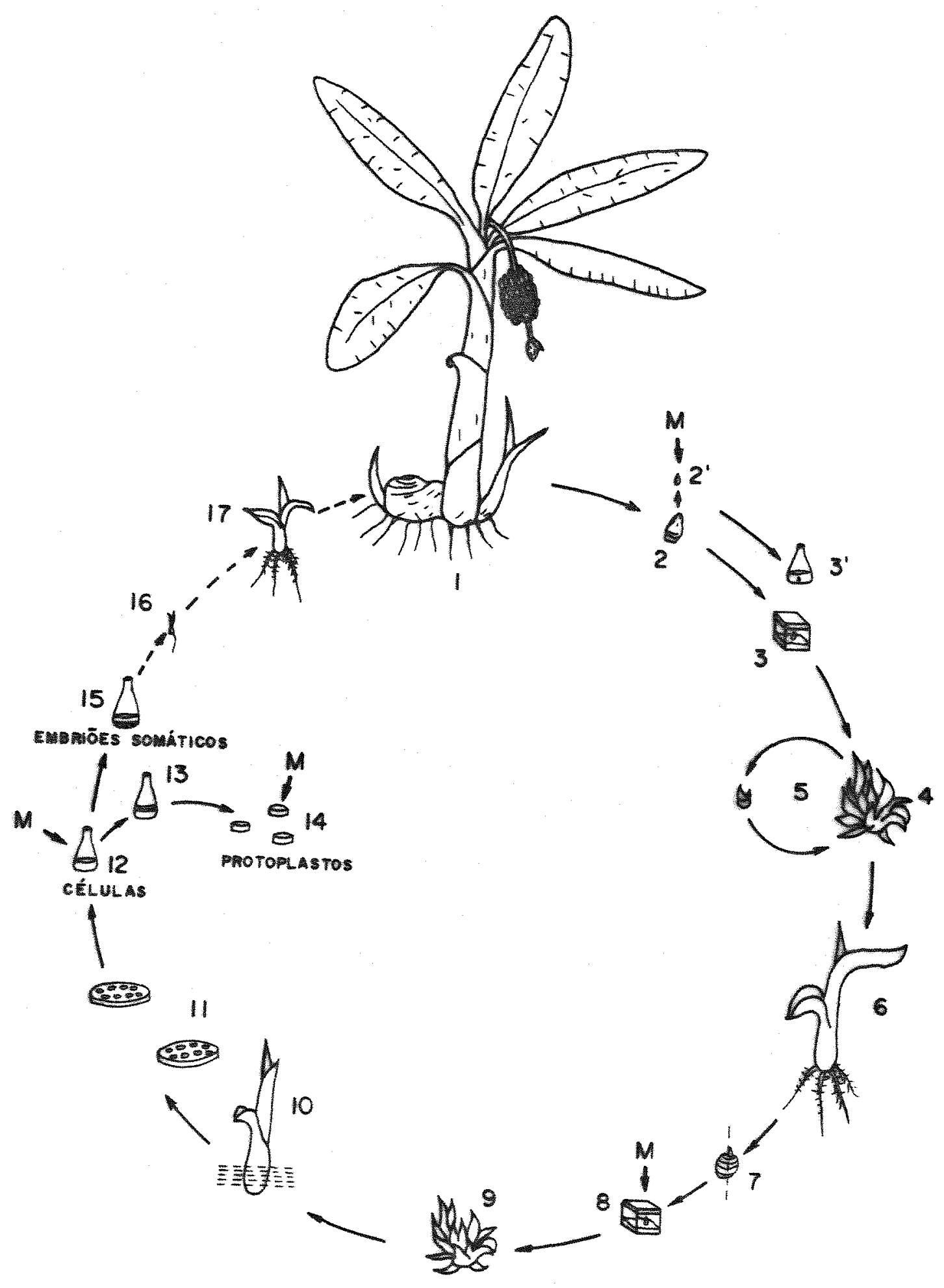

Figura 15 - Desenho ilustrativo da sequencia dos trabalhos realizados na presente pesquisa. 
A partir destes explantes iniciais foram obtidas novas brotações (4), as quais puderam ser micropropagadas por diversas gerações vegetativas (5).

As plântulas obtidas in vitro foram então enraizadas (6) e transferidas para o solo em casa de vegetação, ou serviram de fonte para a extração de novos explantes (7) para reinicio da cultura (8).

Utilizando-se brotos obtidos através da micropropagação (10), puderam ser extraidas seç̧ões do rizoma e pseudo caule, que serviram como explantes iniciais para a indução de estruturas embriogênicas (11). A partir destas estruturas obtidas foram confeccionadas suspensões celulares (12), as quais serviram de fonte para subcultivos (13) e isolamento de protoplastos (14), ou serviram para o desenvolvimento de embriões somáticos (15), os quais poderão ser convertidos em plântulas (16), as quais após aclimatadas em casa de vegetação (17) poderão ser levadas ao campo. - uso de mutagênicos (M) pode ser feito em várias das etapas citadas, como ilustrado nesta figura. Se o mutagênico for utilizado em ápices caulinares $\left(2,2^{\prime} \mathrm{e} 8\right)$, como na presente pesquisa, haverá necessidade de vârias propagações vegetativas antes da seleção de mutantes, devido ao quimerismo. Se outros caminhos fossem utilizados, como a embriogênese somática (12) ou protoplastos (13), isto não seria necessário. 


\section{CONCLUSŌBS}

1. Para micropropagação pode-se utilizar ápices caulinares de maiores ou menores. Quanto maior a dimensão dos explantes, maior será a velocidade de multiplicação, embora seja maior a possibilidade de contaminação. os ápices caulinares que possuam em torno de $0,7 \mathrm{~cm}$ de diâmetro basal, ou superiores, possuem maior capacidade de brotação quando são removidas as bainhas foliares.

2. Para a micropropagação da bananeira pode-se utilizar meio líquido sob agitação ou meio semi-solido. o primeiro tende a apresentar maior número de brotações em menor tempo, porém a sua utilização exige maiores cuidados para se evitar possiveis contaminações, não dá sustentação aos explantes e exige a utilização de agitadores para oxigenação do meio de cultura.

3. Os tratamentos de 5,0 e $20,0 \mathrm{mg} / 1$ de BAP foram os que induziram maior brotação durante o cultivo de ápices caulinares de bananeira "Maçã", porém para micropropagação, recomenda-se a utilização de concentrações em torno de 3,5 a $4,0 \mathrm{mg} / 1$ deste regulador de crescimento, para obter uma boa multiplicação in vitro e diminuir a probabilidade de aparecimento de variantes somaclonais. 
4. Para a indução do enraizamento en plântulas de bananeira "Maçã" in vitro, recomenda-se a utilização de 0,1 mg/1 de IBA ou NAA, em meio semi-sólido, na ausencia de citocinina. A utilização destes reguladores de crescimento nestas concentrações permite o enraizamento das plantulas de bananeira, as quais após aproximadamente 20 dias podem ser transferidas para a casa de vegetação sem necesidade de inoculação em novo meio para desenvolvimento das plântulas.

5. A dose que causou a letalidade de 50 dos ápices caulinares tratados $\left(L D_{50}\right)$, de bananeira "Maçã" (grupo $A A B$ ), situase por volta de 40 Gy. Esta dose foi a maior dose utilizada que permitiu uma boa capacidade de brotação dos explantes, sendo sugerida para programas de indução de mutaçōes visando o melhoramento deste cultivar.

6. o sistema de avaliação da radiossensitividade de ápices caulinares de bananeira, cultivados em meio semi-solido, através de pesagens, permite maior velocidade na avaliação dos resultados (em torno de 35 dias) em relação à avaliação pelo número de brotos. No entanto en trabalhos onde visa-se uma quantificação do potencial de brotação dos explantes deve-se utilizar contagem do número de brotos o que levará, pelo menos o dobro do tempo (75 dias). 
7. O avanço de quatro geraçōes vegetativas pareceu ser satisfatorio para o isolamento dos setores mutados obtidos após a irradiação de apices caulinares de bananeira, sendo que no final desta fase, ainda in vitro, foi possivel a observação de variantes fenotipicos para a variegação foliar.

8. o cultivo de ápices caulinares de bananeira "Maçã" in vitro e seu subcultivo por 4 geraçōes vegetativas em meio modificado de MS, contendo $5,0 \mathrm{mg} / 1$ de BAP permitiu o surgimento de $0,85 \%$ de variantes somaclonais, os quais foram constituidos de plantas com folhas estreitas, planta alta com peciolos longos e plantas com alteração para a pigmentação do pecíolo e pseudocaule (maior teor de antocianina).

9. O tratamento com raios gama elevou a frequência dos variantes fenotípicos observados em casa de vegetação, as doses que mais contribuiram para estes aumentos foram as de 40 Gy e 60 Gy. A primeira, que situou-se ao redor do $L_{50}$, apresentou $13,49 \%$ das plantas com alterações, uma das quais de porte anão, e a dose de 60 Gy apresentou $9,24 \%$ de variantes.

10. O cultivo do Fusarium em BDA por 15 dias foi ideal para a obtenção de maior número de esporos para a confecção de suspensão de esporos. 
11. O processo de seleção de plantas através de rega com $50 \mathrm{ml}$ de suspensão com $5 \times 10^{4}$ esporos/ml mostrou-se eficiente e rápido. Com 20 ou 30 dias pôde-se observar a evolução da Fusariose nas plantas de bananeira "Maçã" inoculadas, porém não foram encontradas, até o momento, plantas resistentes.

12. Foi satisfatoria a utilização do Dicamba como regulador de crescimento indutor da embriogênese somática, nas concentraçōes de $6,63 \mathrm{mg} / 1$ para o cultivar Maçã, 3,35 mg/1 para o clone $\mathrm{GN}-60$ e $2,0 \mathrm{mg} / 1$ para o cultivar Nanicão.

13. As regiões situadas logo abaixo e logo acima do meristema apical (constituidas de tecidos do rizoma e pseudocaule) de plântulas de bananeira, responderam com maior intensidade à indução de estruturas embriogênicas para os três cultivares observados.

14. As concentrações de sacarose a 2 e $4 \%$ induziram respostas diferenciadas para a produção de calos e estruturas globulares para os diferentes genótipos estudados.

15. As estruturas globulares obtidas até o momento não apresentaram germinação satisfatoria, emitiram radiculas mas a formação da parte aérea foi inadequada, não permitindo a recuperação de plantas. 
16. A partir das estruturas embriogênicas formadas foi possivel a obtenção de cultura de suspensões celulares, de onde foram isolados protoplastos. 


\section{REFERENCIAS BIBLIOGRAFICAS}

AMMIRATO, P.V. Embryogenesis. In: EVANS, D.A.; SHARP, W.R.; AMMIRATO, P.V.; YAMADA, Y. ed. Handbook of plant cell culture. New York, MacMillan, 1984. v.1, p.82-123.

BÁKRY, F. Embriogênese somática em bananeira. Revista Brasileira de Fruticultura, Cruz das Almas, 10(1): 75-80, 1988.

BAKRY, F. ROSSIGNOL, L. Analyses des capacités de callogénés et d'órgannogénése obteneus à partir de différents tissues de bananiers (Musa spp., Musáceas). Truits, Paris, 40(11): 697-8, 1985.

BALAKRISHNAMURTHY, G. S SREE RANGASAMY, S.R. Regeneration of banana plantlet from in vitro culture of floral apices. current Science, Bangalore, $57(5): 270-2,1988$.

BANERJEE, N. \& DE LANGHE, E. A tissue culture technique for rapid clonal propagation and storage under minimal growth conditions of Musa (banana and plantain). Plant Cell Reports, Heidelberg, 4: $351-4,1985$ 
BANERJEE, N.; VUYLSTEKE, D.; DE LANGHE, E. Meristen tip culture of Musa: histomorphological studies of shoot bud proliferation. In: WITHERS, L.A. A ALDERSON, P.G., ed. Plant tissue culture and its agricultural applications. London, Butterworths, 1986. p. $139-47$

BARKER, W.G. \& STEWARD, F.C. Growth and development of the banana plant. 1. The growing regions of the vegetative shoot. Annals of Botany, London, 26: 389-411, 1962.

BERG, L.A. BUSTAMANTE, M. Heat treatment and meristem culture for the production of virus free bananas. Phytopathology, Lancaster, 64: $320-2,1974$.

BROERTJES, C. \& VAN HARTEN, A.M. APplication of wutation breeding methods in the improvement of vegetatively propagated crops. Amsterdam, Elsevier, 1978. 316p.

BROERTJES, C. VAN HARTEN, A.M. Applied mutation breeding for vegetatively propagated crops. Amsterdam, Elsevier, 1988. $313 \mathrm{P}$. 
BUDDENHAGEN, I.W. Disease susceptibility and genetics in relation to breeding of bananas and plantains. In:

INTERNATIONAL WORKSHOP ON BANANA AND PLANTAIN BREEDING STRATEGIES. 21., Cairns, 1986. Proceedings. Brisbane, ACIAR, 1987. p. 95-109.

BUDDENHAGEN, I.W. Banana breeding and Fusarium wilt. In: PLOETZ, R.C., ed. Fusarium wilt of bananas. St. Paul, APS Press, 1990. p. 107-13.

BUSCAR a saida. Informativo Semanal da Cacex, Rio de Janeiro, 20(951): 2-11, jun. 1985.

CARES, J.E. Moko situação da doença no Brasil. Revista Brasileira de Fruticultura, Cruz das Almas, 10(1): 81-8, 1988.

CHALFOUN, S.A. \& GODINHO, F.P. Doenças da bananeira. Informe Agropecuário, Belo Horizonte, 12(133): 39-44, jan. 1986.

CHEESMAN, E.G. Principles of banana breeding. Tropical Agriculture, Trinidad, 11: 132-7, 1934.

CHEN, T.C.C.; MAROSITCH, J.; THOMPSON, B.G. Genotypic effects on somatic embryogenesis and plant regeneration from callus cultures of alfalfa. Plant cell Tissue and organ culture, Dordrecht, 8: 73-81, 1987 . 
CRONAUER, S.S. \& KRIKORIAN, A.D. MUItiplication of Musa from excised stem tips. Annals of Botany, London, 53: 321-8, $1984 \mathrm{a}$.

CRONAUER, S.S. KRIKORIAN, A.D. Rapid multiplication of bananas and plantains by in vitro shoot tip culture. Hortscience, Alexandia, 19: 234-5, 1984b.

CRONAUER-MITRA, S.S. \& KRIKORIAN, A.D. Banana (Musa spp.). In: BAJAJ, Y.P.S., ed. Biothecnology in agriculture and forestry trees. Berlin, Springer-verlag, 1986. v.1, p.233-52.

CRONAUER-MITRA, S.S. \& KRIKORIAN, A.D. Adventitious shoot production from calloid structures of banana. Plant cell Reports, Heidelberg, 6: 443-5, 1987.

CRONAUER-MITRA, S.S. \& KRIKORIAN, A.D. Determinate floral buds of plantain (Musa $A A B$ ) as a site of adventitious shoot formation. Annals of Botany, London, 61: $509-12,1988$ a.

CRONAUER-MITRA, S.S. \& KRIKORIAN, A.D. Plant regeneration via somatic embryogenesis in the seeded diploid Musa ornata Roxb. Plant Cell Reports, Heidelberg, 7: 23-5, 1988b. 
CRONAUER-MITRA, S.S. \& KRIKORIAN, A.D. Temporal, spacial, and morphological aspects of multiplication in aseptically cultured Musa clones. In: VALENTINE, A.F., ed. Forest and crop biotechnology; progress and prospects. New York, Springerverlag, $1988 \mathrm{c} \cdot \mathrm{p} .45-57$.

DE GUZMAN, E.; UBALDE, E.M.; ROSARIO, A.G. Banana and coconut in vitro cultures for induced mutation studies. In: International Atomic Energy Agency. Improvement of vegetatively propagated plants and tree crops through induced mutations. Vienna, IAEA, 1976. p.33-54.

DE GUZMAN, E.V.; ROSARIO, A.G.DEL; PAGCALIWAGAN, P.C. Production of mutants by irradiation of in vitro cultured tissues of coconut and banana and their mass propagation by the tissue culture technique. In: International Atomic Energy Agency. Induced utations in vegetatively propagated plants II. Vienna, IAEA, 1982. p.113-38.

DHED'A, D.; DUMORTIER, F.; PANIS, B.; VUYLSTEKE, D.; DE LANGHE, E. Plant regeneration in cell suspension cultures of the cooking banana CV. "Bluggoe" (Musa spp. ABB group). Fruits, Paris, $46(2): 125-35,1991$. 
ESCALANT, J.V. \& TEISSON, C. Somatic embryogenesis and plants from immature zygotic embryos of the species Musa acuminata and Musa balbisiana. Plant Cell Reports, Heidelberg, 7 : $665-8,1989$.

FAO PRODUCTION YEARBOOK - 1990, ROME, 44: 169-70, 1991.

FISHER, J.B. Leaf-opposed buds in Musa: their development and a comparison with allied monocotyledons. Aerican Journal of Botany, Columbus, $65(7): 781-91,1978$.

FOURE, E.; MOULIOM-PEFOURA, A.; MOURICHON, X. Etude de la sensibilité variétale des bananiers et des plantains à Mycosphaerella fijiensis Morelet au Cameroun. Caractérisation de la résitance au champ de bananiers appartenant à divers groupes génétiques. Fruits, Paris, 45(4):339-45, 1990.

FREARSON, E.M.; POWER, J.B.; COCKING, E.C. The isolation, culture and regeneration of Petunia leaf protoplasts. Developmental Biology, Duluth, 33: 130-37, 1973.

FRUTAS frescas. Infomativo Semanal da Cacex, Rio de Janeiro, $23(1074): 6-7, \operatorname{majo} 1988$ 
GAMBORG, O.L.; SHYLUK, J.P.; SHAHIN, E.A. Isolation, fusion and culture of plant protoplasts. In: THORPE, T.A., ed. Plant tissue culture; methods and applications in agriculture. New York, Academic Press, 1981. p.115-53

GODINHO, F.P. Efeito de doses de 6 - Benzilaminopurina na produção de mudas de bananeira (Musa sp) cultivar Prata, pelo método de propagação rápida in vivo. Lavras, 1991. 49p. (Mestrado Escola Superior de Agricultura de Lavras)

GUPTA, P.F. Eradication of mosaic disease and rapid clonal multiplication of bananas and plantains through meristem tip culture. Plant Cell, Tissue and Organ Culture, Dordrecht, 6: $33-9,1986$.

HAMILTON, K.S. Reproduction of banana from adventitious buds. Tropical Agriculture, Trinidad, 42(1):69-73, 1965.

HANDRO, W. Mutagenesis and in vitro selection. In: THORPE, T.A., ed. Plant tissue culture: methods and appications in agriculture, New York, Academic Press, 1981. p.155-80.

HU, C.Y. \& WANG, P.J. Meristem, shoot tip and bud cultures In: EVANS, D.A.; SHARP, W.R.; AMMIRATO, P.; YAMADA, Y., ed. Handbook of plant cell culture. New York, Macmillan Publ., 1983. v.1, p.117-227. 
HWANG, S.C. KO, W.A. SOmaclonal variation of bananas and screening for resistance to Fusarium wilt. In: INTERNATIONAL WORKSHOP ON BANANA AND PLANTAIN BREEDING STRATEGIES, $21 .$, Cairns, 1986. Proceedings. Brisbane, ACIAR, 1987. p.151-6.

ILLG, R.D. Variaçào somaclonal. In: TORRES, A.C. \& CALDAS, L.S. Técnicas e aplicaçóes da cultura de tecidos de plantas. Brasilia, ABCTP; EMBRAPA-CNPH, 1990. p.287-95.

KRIKORIAN, A.D. In vitro culture of bananas and plantains: background, update and call for information. Tropical Agriculture, Trinidad, 66: 194-200, $1988 \mathrm{a}$.

KRIKORIAN, A.D. Protoplast culture of perennials. In: VAN BRAGT, J., ed. Scientia Horticulturae, Amsterdam, 37: 277-93, 1988b.

KRIKORIAN, A.D. Baseline tissue and cell culture studies for use in banana improvement schemes. In: PLOETZ, R.C., ed. Fusarium wit of banana. St. Paul, APS Press, 1990. p.127-33.

KRIKORIAN, A.D. \& CRONAUER, S.S. BaNaNa. In: SHARP, W.R.; EVANS, D.A.; AMMIRATO, P.; YAMADA, Y., ed. Handbook of plant cell culture. New York, Macmillan Publ., 1984. v.2, p.327-48. 
KRIKORIAN, A.D. SCOTT, M.E. MUsa callus and cell culture; strategies, achievements and directions. In: International Atomic Energy Agency. In vitro wutation breeding of bananas and plantains I. Vienna, IAEA, 1990. p.9-23.

LAMEIRA, O.A. Propagação in vitro da bananeira Musa sp. através da cultura de ápice caulinar. Lavras, 1987. 39p. (MestradoEscola superior de Agricultura de Lavras)

LARKIN, P.J. \& SCOWCROFT, W.R. Somaclonal variation, a novel source of variability from cell culture for plant improvement. Theoretical and Applied Genetics, Berlin, 58: 193-214, 1981.

LEHMANN-DANZINGER, H. The distribution of Moko disease in central and South America and its control on plantains and bananas. In: CTA EA. IMPROVING CITRUS AND BANANA PRODUCTION IN THE CARIBBEAN THROUGH PHYTOSANITATION. ST. LUCIA, W.I. 2-5 DeC. 1986 proceedings. Lome, CTA, 1987. p.130-52.

LIU, L.J.; ROSA, E.; LIZARDI, E.; AROCHO, A.; DIAZ, N.; RODRIGUEZ, J.A. In vitro propagation of plantain (Musa acuminata $\mathrm{x}$ M. balbisiana $A A B$ ) and banana ( $M$. acuminata $A A A$ ) in Puerto Rico. Joumal of Agricultural University of Puerto Rico, Río Piedras, $73(1): 51-8,1989$. 
MARRIOT, J. \& LANCASTER, P.A. Bananas and plantains. In: CHAN, H.T., ed. Handbook of tropical foods. New York, Marcel Dekker, 1983. p.85-143.

MARTINEZ, J.A. Banana; principais doenças da bananeira. Toda Fruta, são paulo, 1(8): 29-31, dez. 1986.

MEDINA, J.C. Cultura. In: MEDINA, J.C. coord. Banana. Campinas, ITAL, 1978. p.7-62.

MENDES, B.M.J. \& RODRIGUES, B.I.F.P. Uso de filtrado tóxico da cultura de Fusarium oxysporum f. sp. cubense e de ácido fusárico na cultura de ápices meristemáticos de bananeira (Musa spp). Fitopatologia Brasileira, Brasilia, 16(2): 58, jun. 1991.

MENDES, B.M.J.; RODRIGUES, B.I.F.P; DOMINGUES, E.T; TULMANN NETO, A. Inoculação de Fusarium oxysporum f.sp. cubense em plantas jovens de bananeira. Suma Phytopathologica, Piracicaba, 15: $31,1989$.

MEREDITH, D.S. L LAWRENCE, J.S. Black leaf streak disease of bananas, Tropical Agriculture, Trinidad 47(4): 276-87, 1970 .

MOREIRA, R.S. Banana; teoria e prática de cultivo. campinas, Fundação Cargil1, 1987. 335p. 
MOREL, G. WETMORE, R.H. Fern callus tissue culture. American Journal of Botany, Columbus, 38: 141-3, Feb. 1951.

MURASHIGE, T. Plant propagation through tissue cultures. Annual Review of Plant Physiology, Palo Alto, 25: 135-66, 1974.

MURASHIGE, T. \& SKOOG, F. A revised medium for rapid growth and bioassays with tobacco tissue cultures. Physiologia plantarum, Copenhagen, 15:473-97, 1962 .

NOVAK, F.J. Musa biotechnology. In: HAMMERSCHLAG, F.A. \& LITZ, R., ed. Biotechnology of perennial fruit crops. Walingford C.A.B. International, 1991. p.120-52.

NOVAK, F.J.; AFZA, R.; VAN DUREN, M.; OMAR, M.S. Mutation induction by gamma irradiation of in vitro cultured shoot-tips of banana and plantain (Musa cvs.). Tropical Agriculture, Trinidad, $67: 21-8,1990$.

NOVAK, F.J.; DOMINI, B.; HERMELIN, T.; MICKE A. Potencial of banana and plantain improvement through in vitro mutation breeding. ACORBAT Memórias VIII Reunión, CATIE, Turrialba, Costa Rica, $1987 . \quad p .67-70$. 
NOVAK, F.J.; AFZA, R.; MONPURGO, R.; VAN DUREN, M.; SACCHI, M.; KHATRI, A. Improvement of Musa through biotechnology and mutation breeding, 1992. (in press).

NOVAK, F.J.; AFZA, R.; VAN DUREN, M.; PEREA-DALLOS, M.; CONGER, B.V.; XIAOLANG, T. Somatic embryogenesis and plant regeneration in suspension cultures of dessert (A and AA) and cooking ( $\mathrm{ABB}$ ) bananas (Musa spp.). Bio/Technology, New York, 7 : $154-9,1989$.

NOVAK, F.J; AFZA, R.; PHADVIBULYA, V.; HERMELIN, T.; BRUNNER, H.; DONINI, B. Micropropagation and radiation sensitivity in shoot tip cultures of banana and plantain. In: International Atomic Energy Agency. Nuclear techniches and in vitro culture for plant improvement. Vienna, IAEA, 1986. p.167-74.

OMAR, M.S.: NOVAK, F.J.; BRUNNER, H. In vitro action of ethylmethanesulphonate on banana shoot tips. Scientia Horticulturae, Amsterdam, 40:283-95, 1989.

OZIAS-AKINS, P. \& VASIL, I.K. Nutrition of plant tissue cultures. In: VASIL, I.K. Cell culture and somatic cell genetics of plants. New York, Academic Press. 1985, v.2, p.129-47 
PEGG, K.G. LANGDON, P.W. Fusarium wilt (Panama Disease): a review. In: INTERNATIONAL WORKSHOP ON BANANA AND PLANTAIN BREEDING STRATEGIES, 21., Caims, 1986. Proceedings. Brisbane, ACIAR, 1987. p.114-8.

PEREA-DALLOS, M. \& NOVAK, F.J. Resultados promisorios en el mejoramiento genetico atraves de mutagenesis $Y$ regeneracion de plantas de Musa spp via embriogenesis somatica. Boletin Cientifico Aceviv, Bogotá, 3: 29-32, ju1. 1988.

PERSLEY, G.J. DE LANGHE, E.A., ed. BANANA AND PLANTAIN BREEDING STRATEGIES; PROCEEDINGS OF AN INTERNATIONAL WORKSHOP HELD AT CAIRNS, Oct. 1986. Proceedings 21. Brisbane, ACIAR, 1987.

REUVENI, o. Methods for detecting somaclonal variants in 'Willians' bananas. In: JARRET, R.L., ed. Identification of genetic diversity in the genus Musa, Montpellier, INIBAP, 1988. p. p. 108-13.

ROWE, P.R. Breeding bananas and plantains. Plant Breeding Reviews, New York, 2: 135-55, 1984. 
ROWE, P.R. \& ROSALES, F.E. Breeding bananas and plantains with resistance to Black Sigatoka. In: FULLERTON, R.A. STOVER, R.H., ed. Sigatoka leaf spot diseases of bananas, san Jose, INIBAP, 1989. p. 243-51.

SANNASGALA, K.; DUMORTIER, F.M.; DE LANGHE, E.A.L. Somatic embryogenesis from Musa proliferating shoot tips: Histological Details. In: International Atomic Energy Agency. In vitro wutation breeding of bananas and plantains I. Vienna, IAEA, 1990. p. 24-8.

SCHENK, R.U. \& HILDEBRANDT, A.C. Medium and techniques for induction and growth of monocotyledonous and dicotyledonous plant cell cultures. Canadian Journal of Botany, ottawa, 50: $199-204,1972$.

SCHULTHEIS, J.R.; CHEE, R.P.; CANTLIFFE, J. Embriões somáticos e sementes sintéticas. In: TORRES, A.C. \& CALDAS, L.S. Técnicas e aplicaçōes da cultura de tecidos de plantas. Brasilia, ABCTP; EMBRAPA-CNPH, 1990. p.287-95.

SHEPHERD, K. Melhoramento genético da bananeira. In: SIMPósIo SOBRE BANAMEIRA PRATA, 1., Cariacica-ES., nov. 1983. Anais. Cariacica, EMCAPA; EMBRAPA, 1983. p.121-46 (Emcapa, Doc. 4) 
SHEPHERD, K. A bananeira: taxonomia e morfología. In: SIMPÓSIO BRASILEIRO SOBRE BANANICULTURA, 1., Jaboticabal, dez. 1984. Anais. Jaboticabal, Faculdade de ciências Agrárias e Veterinárias - UNESP, 1984a. p.49-74

SHEPHERD, K. Melhoramento genético da bananeira. In: SIMPÓsIO BRASILEIRO SOBRE BANANICULTURA, 1., Jaboticabal, dez. 1984 . Anais. Jaboticabal, Faculdade de Ciências Agrárias e Veterinárias, $1984 b$. p.75-94

SHEPHERD, K.; DANTAS, J.L.L.; ALVES, E.J. Melhoramento genético da bananeira. Infore Agropecuário, Belo Horizonte, 12(133): 11-9, jan. 1986.

SIMÃo, S. Manual de fruticultura. São Paulo, ceres, 1971. $530 \mathrm{p}$

SIMMONDS, N.W. The evolution of the bananas. London, Longman, 1962. 170p.

SIMMONDS, N.W. Bananas. 2.ed. London, Longman, 1966. 466 p.

SIMMONDS, N.W. \& SHEPHERD, K. The taxonomy and origins of the cultivated bananas. Journal of the Linnean Society of London Botany, London, 55: 302-12, 1955. 
SMITH, M.K. A review of factors influencing the genetic stability of micropropagated bananas. Fruits, Paris, 43: 219-23, 1988 .

SPIEGEL-ROY, P. EConomic and agricultura impact of mutation breeding in fruit trees. Mutation Breeding Review, Vienna, (5): $1-25,1990$.

STOVER, R.H. Leaf spot of bananas caused by mycosphaerella musicola: role of conidia in epidemiology. Phytopathology, Lancaster, 60: 856-60, 1970.

STOVER, R.H. Sigatoka leaf spots of bananas and plantains. Plant Disease, St. Paul, 64(8): 750-6, 1980.

STOVER, R.H. \& BUDDENHAGEN, I.W. Banana breeding: polyploidy disease resistance and productivity. Fruits, Paris, 41: 175$91,1986$.

STOVER, R.H. \& SIMMONDS, N.W. Bananas, 3.ed. Harlow, Longman, 1987. $512 \mathrm{p}$.

STREET, H.E. Plant tissue and cell culture. London, Blackwells, 1973. $503 \mathrm{p}$.

SU, H.J.; HWANG, S.C.; KO, W.H. Fusarial wilt of cavendish bananas in Taiwan. Plant Disease, St. Paul, 70(9): 814-8, 1986. 
SUN, E.J. SU, H.J. Rapid method for determining differential pathogenicity of Fusarium oxysporum f. sp. cubense using banana plantlets. Tropical Agriculture, Trinidad, 61: 7-8, 1984.

SUN, E.J.: SU, H.J.: KO, W.H. Identification of Fusarium oxysporum f. sp. cubense race 4 from soil or host tissue by cultural characters. Phytopathology, Lancaster, 68: 1672-3, 1978.

TEZENAS DU MONTCEL, H. The susceptibility of various cultivated bananas to sigatoka diseases. In: FULLERTON, R.A. \& STOVER, R.H., ed. Sigatoka leaf spot diseases of bananas. São José, Inibap, 1989. p.243-51.

TORRES, A.C. \& CALDAS, L.S. Tecnicas e aplicaçöes da cultura de tecidos de plantas. Brasilia, ABCTP; EMBRAPA-CNPH, 1990. 433p.

TULMANN NETO, A.; DOMINGUES, E.T.; MENDES, B.M.J.; ANDO, A. Metodologia in vivo visando indução de mutações no melhoramento da bananeira "Maçã". Revista Brasileira de Genética, Ribeirão Preto, 12(4): 871-9, 1989.

VUYLSTEKE, D. \& DE LANGHE, E. Feasibility of in vitro propagation of bananas and plantains. Tropical Agriculture, Trinidad, $62(4): 323-8,1985$. 
VUYLSTEKE, D. \& SWENNEN, R. SOmaclonal variation in African plantains. IITA, One, 1(1): 4-10, Sept. 1990.

VUYLSTEKE, D.; SWENNEN, R.; WILSON, G.F.; DE LANGHE, E. Phenotipic variation among in vitro propagated plantains (Musa sp. cultivar ' $A A B$ '). Scientia Horticulturae, Ammsterdam, 36: $79-88,1988$.

WAITE, B.H. Wilt of Helliconia spp. caused by Fusarium oxysporum f.sp. cubense race 3. Tropical Agriculture, Trinidad, 40: 299$305,1963$.

WONG, W.C. In vitro propagation of banana (Musa spp.) initiation, proliferation and development of shoot-tip cultures on defined media. Plant Cell, Tissue and Organ Culture, Dordrecht, 6: 159$66,1986$.

ZIMMERMAN, R.H. \& BROME, O.C. Phloroglucinol and in vitro rooting of apple cultivar cutings. Journal of American Society for Horticultural Science, Alexandria, 106: 648-52, 1981. 
APENDICES 
APENDTCB 1 - Produção mundial e continental de bananas e principais pafses produtores (en 1000 Ton.)

\begin{tabular}{|c|c|c|c|c|}
\hline & $1979-81$ & 1988 & 1989 & 1990 \\
\hline PRODUÇĀO MUNDIAL & 36849 & 44856 & 44965 & 45845 \\
\hline $\begin{array}{l}\text { ÁrRICA } \\
\text { Burundi }\end{array}$ & $\begin{array}{l}4731 \\
1096\end{array}$ & $\begin{array}{l}6068 \\
1574\end{array}$ & $\begin{array}{l}6179 \\
1608\end{array}$ & $\begin{array}{l}6210 \\
1608\end{array}$ \\
\hline $\begin{array}{l}\text { AM. CENTRAL E DO NORTE } \\
\text { Costa Rica } \\
\text { México }\end{array}$ & $\begin{array}{l}7037 \\
1134 \\
1435\end{array}$ & $\begin{array}{l}7238 \\
1162 \\
1566\end{array}$ & $\begin{array}{l}7109 \\
1400 \\
1185\end{array}$ & $\begin{array}{l}7018 \\
1530 \\
1065\end{array}$ \\
\hline $\begin{array}{l}\text { AN. DO SUL } \\
\text { Brasil } \\
\text { Equador }\end{array}$ & $\begin{array}{l}9033 \\
4348 \\
2104\end{array}$ & $\begin{array}{r}11225 \\
5118 \\
2576\end{array}$ & $\begin{array}{r}11652 \\
5502 \\
2576\end{array}$ & $\begin{array}{r}11933 \\
5488 \\
2817\end{array}$ \\
\hline $\begin{array}{l}\text { ÁsIA } \\
\text { India } \\
\text { Filipinas }\end{array}$ & $\begin{array}{r}14480 \\
4403 \\
4006\end{array}$ & $\begin{array}{r}18509 \\
5954 \\
3645\end{array}$ & $\begin{array}{r}18180 \\
6000 \\
3733\end{array}$ & $\begin{array}{r}18803 \\
6200 \\
3803\end{array}$ \\
\hline $\begin{array}{l}\text { EUROPA } \\
\text { Espanha }\end{array}$ & $\begin{array}{l}490 \\
457\end{array}$ & $\begin{array}{l}457 \\
395\end{array}$ & $\begin{array}{l}439 \\
397\end{array}$ & $\begin{array}{l}422 \\
380\end{array}$ \\
\hline $\begin{array}{l}\text { OCEANIA } \\
\text { Papua Nova Guiné }\end{array}$ & $\begin{array}{r}1078 \\
904\end{array}$ & $\begin{array}{l}1359 \\
1100\end{array}$ & $\begin{array}{l}1406 \\
1150\end{array}$ & $\begin{array}{l}1459 \\
1200\end{array}$ \\
\hline
\end{tabular}

Dados extraídos da FAO (1991) 


\section{APQNDICE 2 - Classificação dos cultivares de Musa no Brasil}

\begin{tabular}{llcc}
\hline None & Grau de & Altura & Peso do \\
popular & Ploidia & (m) & cacho (Kg)
\end{tabular}

B. Ouro ou Inajá

$A \bar{A}$

2,5 a 3,5

8

B. "Pisang Mas"

A

B. Caru roxa

A.A

4,0 a 6,5

8

B. Caru verde ou São Domingo

AAA

4,0 a 6,5

8

B. "Grós-Michel"

$A A A$

B. Nanica

AAA

1,2 a 2,0

25

B. Nanicão

AAA

2,2 a 3,2

15 a 45

B. São Tomé

AAA

3,0 a 4,0

B. Branca

$A A B$

B. Maçã ou "Silk"

$A A B$

3,5 a 4,5

7 a 14

B. "Mysore"

$\mathrm{AAB}$

B. Pacova

AAB

3,5 a 4,0

B. Prata

AAB

4,0 a 5,5

15

B. Terra ou Maranhão

$A A B$

4,0 a 5,0

B. Figo ou Marmelo ou "Bluggoe" $A B B$

* Cultivares de bananeira mais conhecidos no Brasil

(adaptado de MEDINA, 1978 e SHEPHERD, 1983 e 1984b) 


\section{APANDICE 3 - Classificação sistemática do gênero Musa}

\section{Número de cromossomos $=10$}

1. Australimusa (Quenslāndia às Filipinas) Fibra - M. textilis

2. Callimusa (Indochina e Indonésia) Frutas - M. troglodytarum Núnero de cromossomos $=11$

3. Eumusa (Sul da India, Japão e Samoa) Fibra - M. basjoo Frutas - M. balbisiana e M. acuminata

4. Rodochlamys (India à Indochina) Ornamental - M. coccinea Núnero de crowossonos $=14$

5. Ingentimusa (Papua - Nova Guine)

Classificação sistemática do gênero Musa: Número básico de cromossomos, Seção, Local de ocorrência, utilização e espécies. Adaptação de STOVER \& SIMMONDS (1987).

\section{APENDICE 4 - Chave de classificação da Seção Eumusa}

NOTA PLOIDIA GENÓTIPO FENÓTIPO

A) CULTIVARES ACUMINATA

$\begin{array}{rrr}2 X & \text { AA } & \text { ACUMINATA } \\ 3 X & \text { AAA } & \text { ACUMINATA } \\ 4 X & \text { AAAA } & \text { ACUMINATA }\end{array}$

B) CULTIVARES HÍBRIDOS NATURAIS

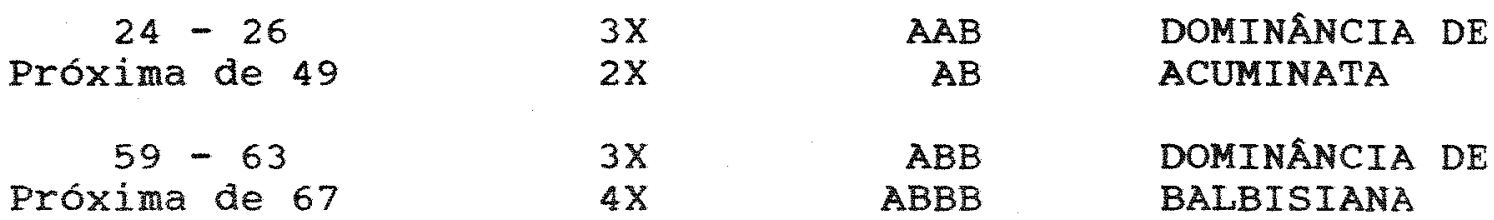

SIMMONDS SHEPHERD (1955) classificaram a seção Eumusa com base na ploidia e através de notas, mostrando a composição genómica em relação às espécies genitoras, segundo SHEPHERD (1984a). 


\begin{tabular}{|c|c|c|c|c|c|}
\hline bananeira & $\mathrm{co}$ & idos & & no & Brasil. \\
\hline cultivares hospedeiros & grupo & $\operatorname{Raça~}_{1}$ & $\begin{array}{r}\text { do } \\
2\end{array}$ & $\begin{array}{c}\text { fungo } \\
3 *\end{array}$ & 4 \\
\hline $\begin{array}{l}\text { B. Ouro ou Inajá } \\
\text { B. "Pisang Mas" }\end{array}$ & $\begin{array}{l}A A \\
A A\end{array}$ & $\begin{array}{l}\mathrm{S} \\
\mathrm{R}\end{array}$ & $\begin{array}{l}? \\
\mathrm{R}\end{array}$ & $?$ & $\begin{array}{l}\mathrm{S} \\
\mathrm{S}\end{array}$ \\
\hline $\begin{array}{l}\text { B. Caru roxa } \\
\text { B. Caru verde ou são Domingo } \\
\text { B. "Grós Michel" } \\
\text { B. Nanica } \\
\text { B. Nanicão } \\
\text { B. São Tomé }\end{array}$ & $\begin{array}{l}\text { AAA } \\
\text { AAA } \\
\text { AAA } \\
\text { AAA } \\
\text { AAA } \\
\text { AAA }\end{array}$ & $\begin{array}{l}\mathrm{S} \\
\mathrm{S} \\
\mathrm{S} \\
\mathrm{R} \\
\mathrm{R} \\
?\end{array}$ & $\begin{array}{l}? \\
? \\
\mathrm{R} \\
\mathrm{R} \\
\mathrm{R} \\
?\end{array}$ & $\begin{array}{l}? \\
? \\
? \\
? \\
? \\
?\end{array}$ & $\begin{array}{l}? \\
? \\
\text { S } \\
\text { S } \\
\text { S } \\
?\end{array}$ \\
\hline $\begin{array}{l}\text { B. Branca } \\
\text { B. Enxerto ou Prata Anã } \\
\text { B. Maça ou Silk } \\
\text { B. "Mysore" } \\
\text { B. Pacova } \\
\text { B. Prata } \\
\text { B. Terra ou Maranhão ou Plátano }\end{array}$ & $\begin{array}{l}\mathrm{AAB} \\
\mathrm{AAB} \\
\mathrm{AAB} \\
\mathrm{AAB} \\
\mathrm{AAB} \\
\mathrm{AAB} \\
\mathrm{AAB}\end{array}$ & $\begin{array}{l}S \\
? \\
S \\
R \\
R \\
S \\
R\end{array}$ & $\begin{array}{l}? \\
? \\
\text { S } \\
\text { R } \\
? \\
? \\
?\end{array}$ & $\begin{array}{l}? \\
? \\
? \\
? \\
? \\
? \\
?\end{array}$ & $\begin{array}{l}? \\
? \\
\text { S } \\
? \\
? \\
? \\
?\end{array}$ \\
\hline B. Figo ou Marmelo ou "Blugoe" & $\mathrm{ABB}$ & $\mathbf{R}$ & $\mathrm{s}$ & ? & $S$ \\
\hline $\begin{array}{l}\text { B. Ouro da Mata } \\
\text { B. Platina }\end{array}$ & $\begin{array}{l}A A A B \\
A A A B\end{array}$ & $?$ & $?$ & $?$ & $\begin{array}{l}? \\
?\end{array}$ \\
\hline
\end{tabular}

* A raça 3 é um patógeno de Heliconia spp.

$\mathrm{R}=$ resistente/tolerante; $\mathrm{S}=$ susceptivel; $?=$ não testado

* Adaptação de MEDINA (1978) e SHEPHERD (1983) (1984). 


\section{APENDICE 6 - Principais caracterfsticas a sere obtidas em cultivares de bananeira conhecidos no Brasil, através de programas de melhoramento genético*.}

\section{Grupo (AAA)}

Subgrupo Cavendish - resistência à raça 4 da Fusariose, à Sigatoka Amarela, à Sigatoka Negra, à Murcha bacteriana, aos nematóides e ao cosmopolites

\section{Grupo (AAB)}

Enxerto - resistência à Fusariose (raça não definida), à Sigatoka Amarela, à Sigatoka Negra e à Murcha bacteriana; maior número de pencas, maiores frutos e resistência ao despencamento de frutos maduros

Maçã - resistência às raças 1 e 2 (pelo menos) da Fusariose, à Sigatoka Negra, a Murcha bacteriana e ao Cosmopolites; menor porte, maior número de pencas e resistência ao despencamento de frutos maduros

Subgrupo Prata ou Pome - resistência à raça 1 (pelo menos) da Fusariose, à sigatoka Amarela, à Sigatoka Negra e à Murcha bacteriana; menor porte, menor ciclo de produção e maior número de pencas.

Subgrupo Terra ou Plátano - resistência à Sigatoka Negra, à Murcha bacteriana e ao cosmopolites; maior vigor de brotação e menor ciclo de produção

\section{Grupo (ABB)}

Subgrupo Figo ou Bluggoe - resistência à raça 2 e 4 da Fusariose, a Murcha bacteriana

* Adaptado de SHEPHERD (1983). 


\section{APANDICE 7 - Principais cultivares de bananeira conhecidos no Brasil originados por mutaçōes espontâneas}

\section{Grupo (AAA)}

Subgrupo* Cavendish - mutaçōes afetando o porte, do Nanica foi originado o Nanicão de porte mais elevado e melhor qualidade de frutos.

Subgrupo Gross Michel - mutaçōes afetando o porte: Gross Michel

Subgrupo caru - mutação para pigmentaçâo do pseudocaule e frutos: Caru verde Caru Roxa

\section{Grupo (AAB)}

Subgrupo Prata ou Pome - mutação no tamanho dos frutos: Prata, Branca, Pacovan

Subgrupo Terra ou Plátano - mutações para tamanho e formato de cachos e de frutos, e para porte: Terra, Terrinha, Pacova, D'angola

\section{Grupo (ABB)}

Subgrupo Figo ou Bluggoe - cerosidade na casca dos frutos: Figo vermelho, Figo Cinza

* O termo subgrupo foi proposto por simmonds ${ }^{6}$ para designar cultivares originados por mutação de um único ancestral (SHEPHERD, 1984b)

- SIMMONDS, N.W. Los platanos. Barcelona, Blume, 1973. $539 \mathrm{p}$. 
APADICE 8 - Distribuição do núaero aproximado de clones existentes e de mutaçōes espontâneas nos diversos grupos de Musa

\begin{tabular}{ccc}
\hline Grupo & clones & mutantes \\
AA & 78 & 1 \\
AB & 5 & 1 \\
AAA & 59 & 32 \\
AAB & 37 & 40 \\
ABB & 24 & 15 \\
BBB & 11 & - \\
AAAA & 3 & - \\
ABBB & 2 & SHEPHERD (1987)
\end{tabular}


APENDICE 9 - $N^{*}$ DE BROTOS OBTIDOS

DE CINCO TIPOS DE APICES

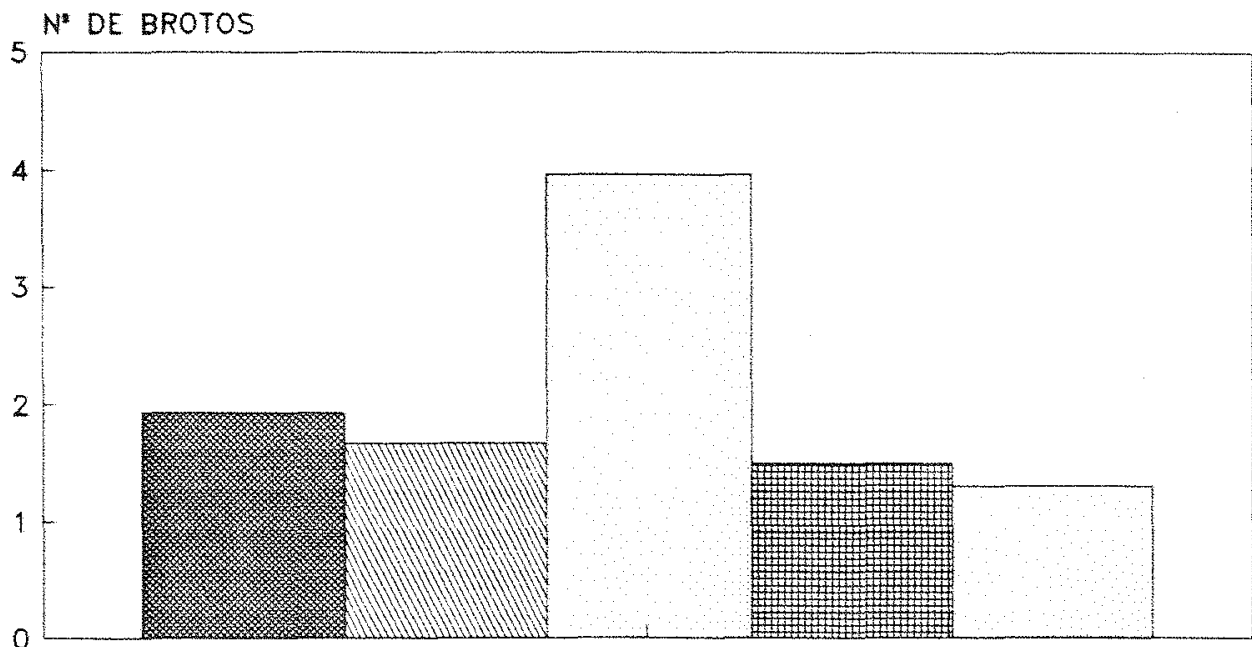

TENPO (30 dias)

TIPO 1 MIIITO $2 \square$ TIPO $3 \quad$ TIPO $4 \quad \square$ TIPO 5

APENDICE 10 - NUMERO MEDIO DE BROTOS EM MEIO SEMI-SOLIDO E LUQUIDO

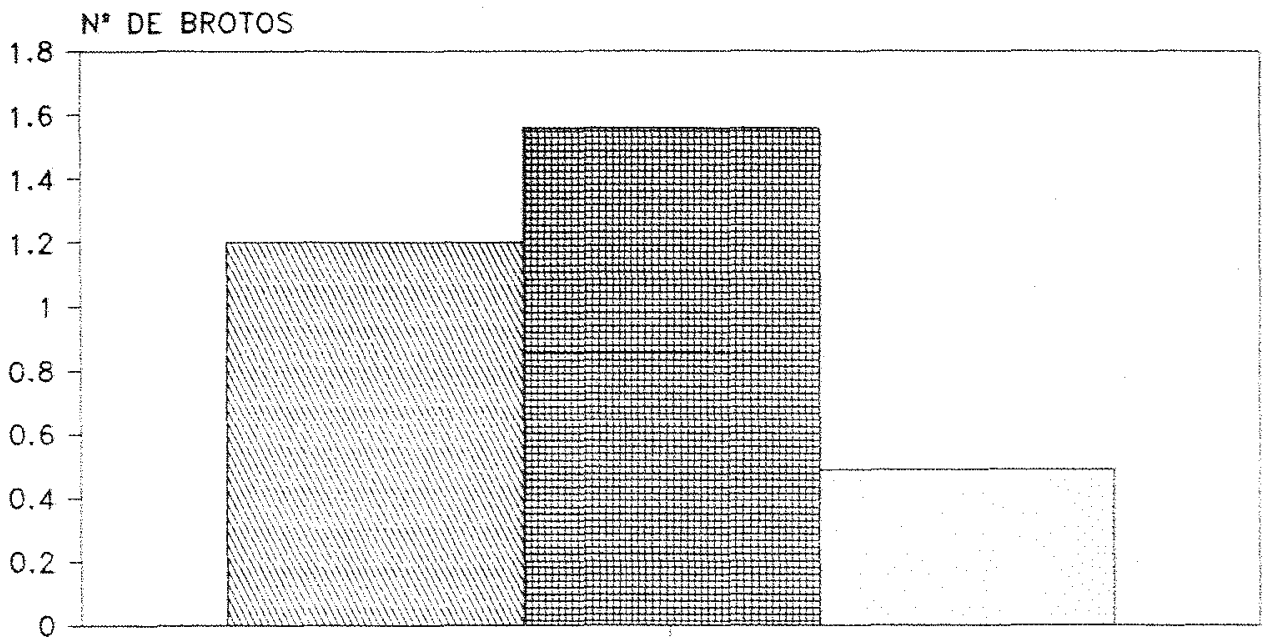

TEMPO ( 20 dios $)$

NWW SEM-SOLDO LOUNOC/AGITACAO ULUIDO S/ AGITACAO 
APENDICE 11 - PESO E NUMERO MEDIOS

DE BROTOS OBTIDOS COM BAP

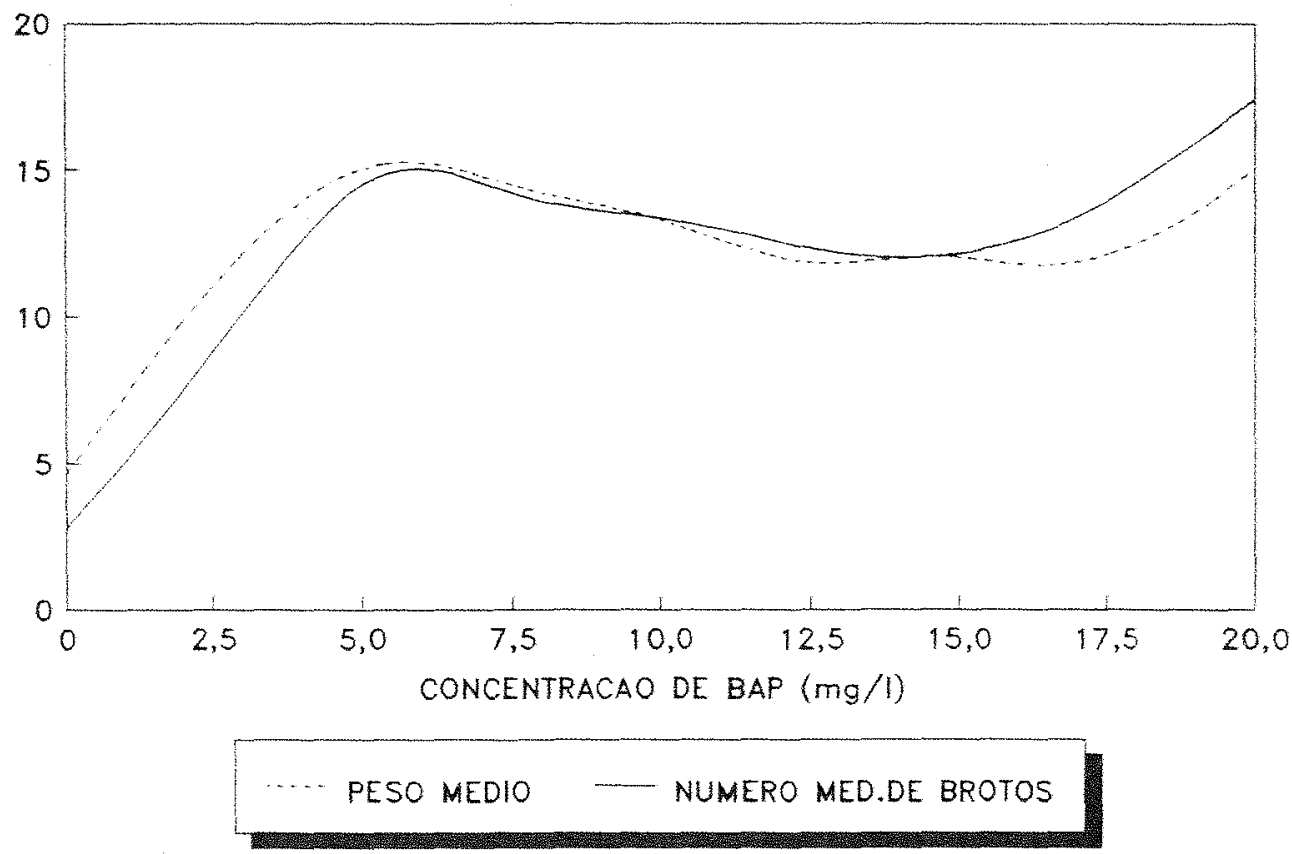

APENDICE 12 - COMPRIMENTO MEDIO DE RAIZES EM MEIO COM AUXINAS

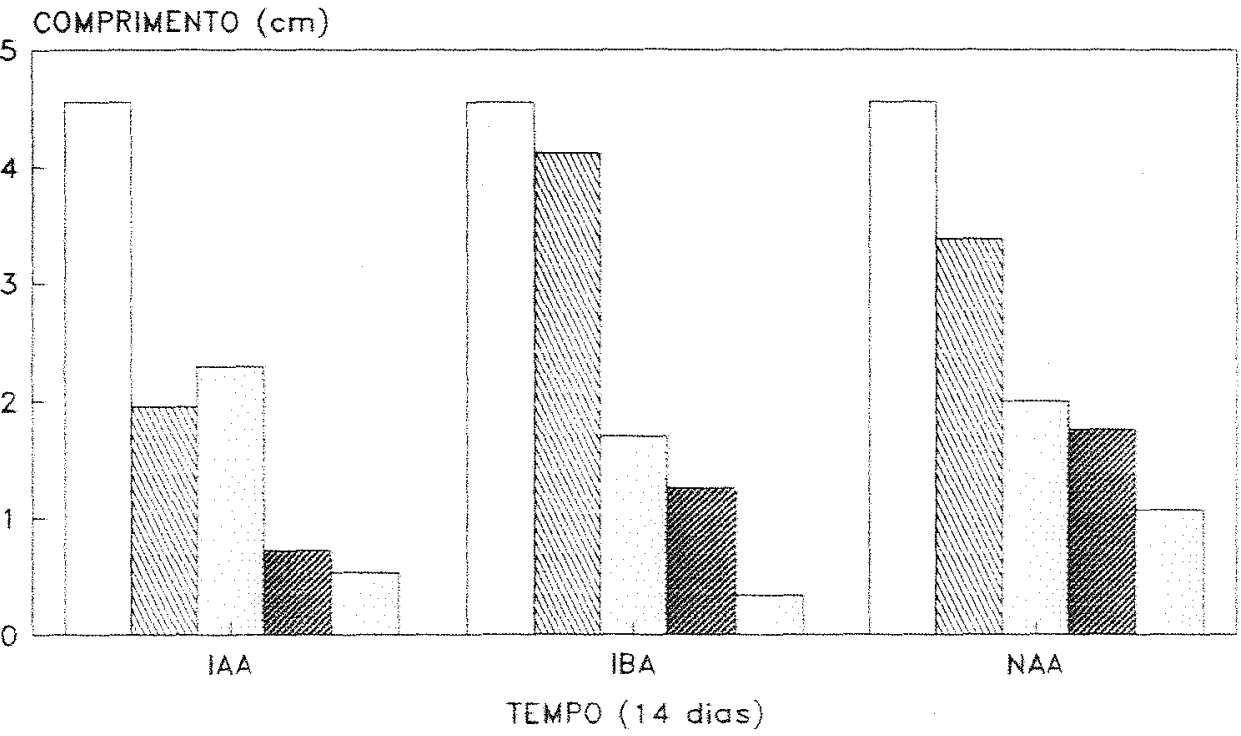

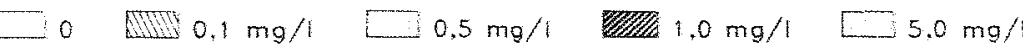


APENDICE 13 - NUMERO MEDIO DE RAIZES

EM MEIO CONTENDO AUXINAS

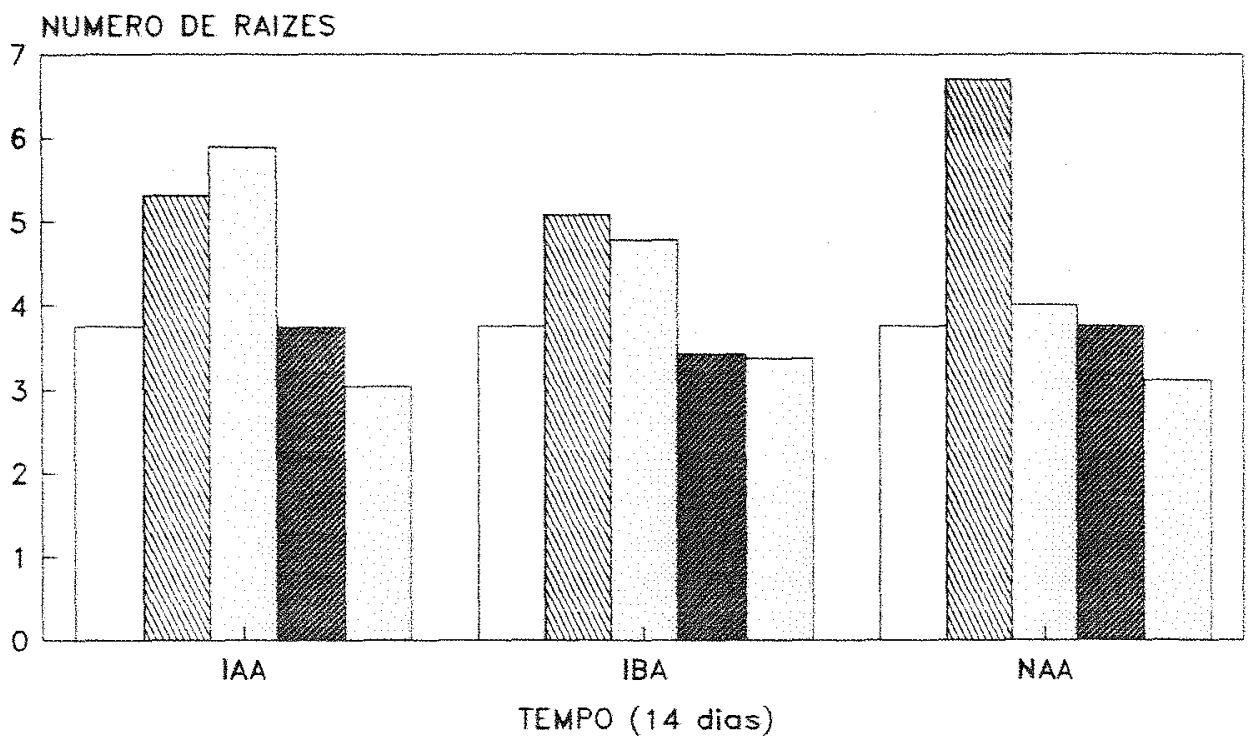

$\square 0 \square 0.1 \mathrm{mg} / \mathrm{s} \quad \square 0.5 \mathrm{mg} / \mathrm{s} \quad 1,0 \mathrm{mg} / \mathrm{t} \quad \square 5,0 \mathrm{mg} / \mathrm{A}$

APENDICE 14 - CRESCIMENTO DE PARTE

AEREA DURANTE ENRAIZAMENTO

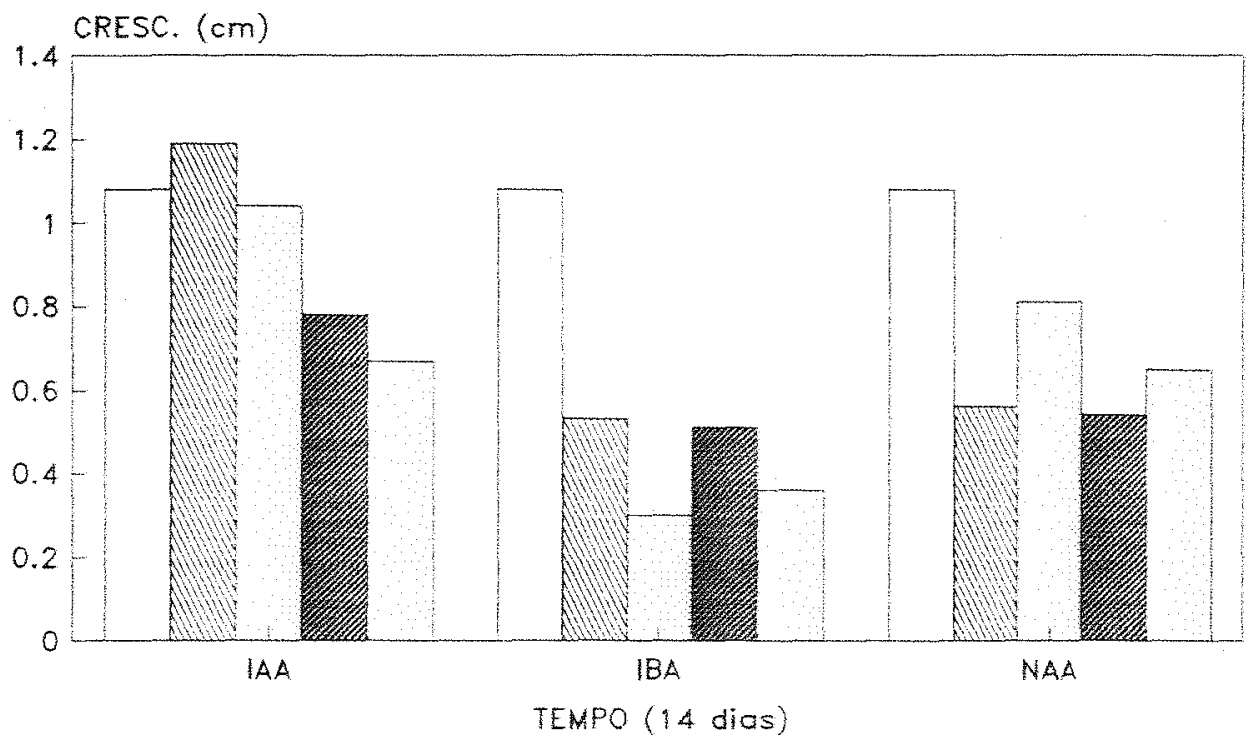

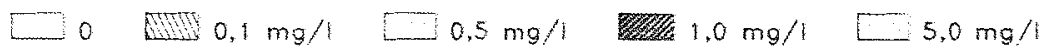


APENDICE 15 - RADIOSSENSITIVIDADE DE

DE APICES MERISTEMATICOS

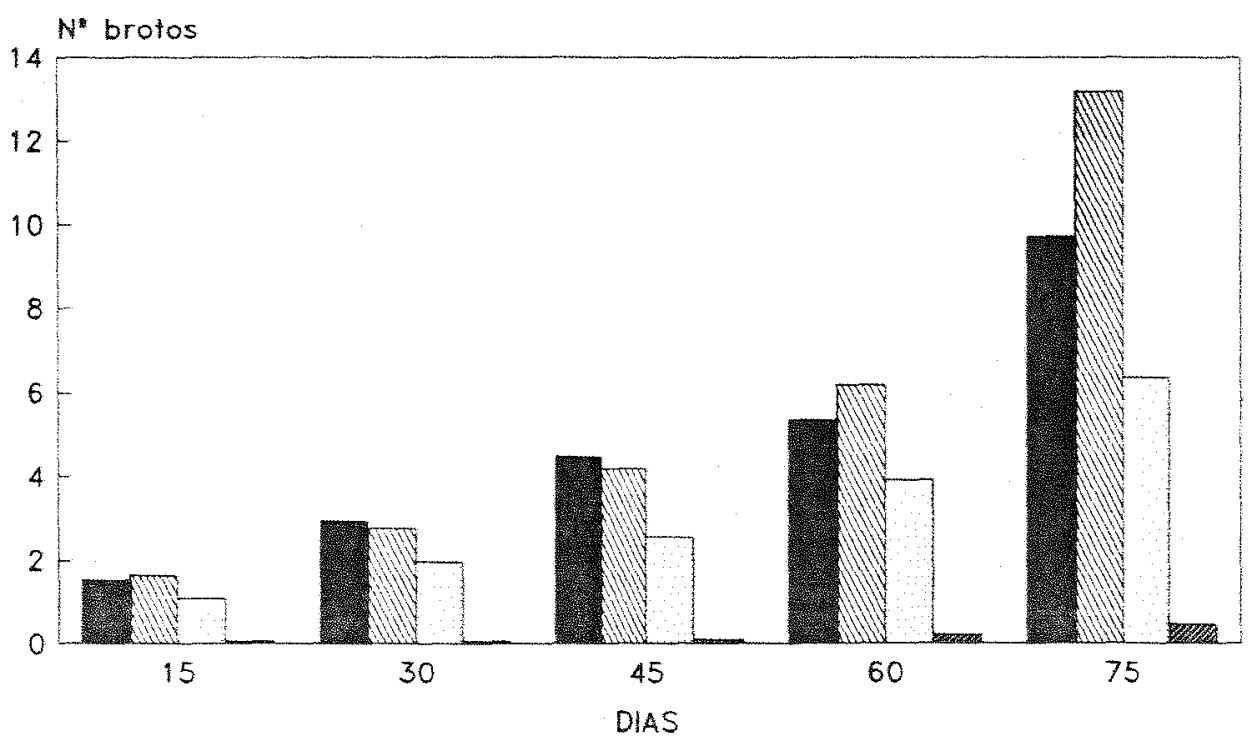

Dog $20 \mathrm{~Gy} \square 40 \mathrm{~Gy}$

APENDICE 16 - RADIOSSENSITIVIDADE DE

APICES MERISTEMATICOS

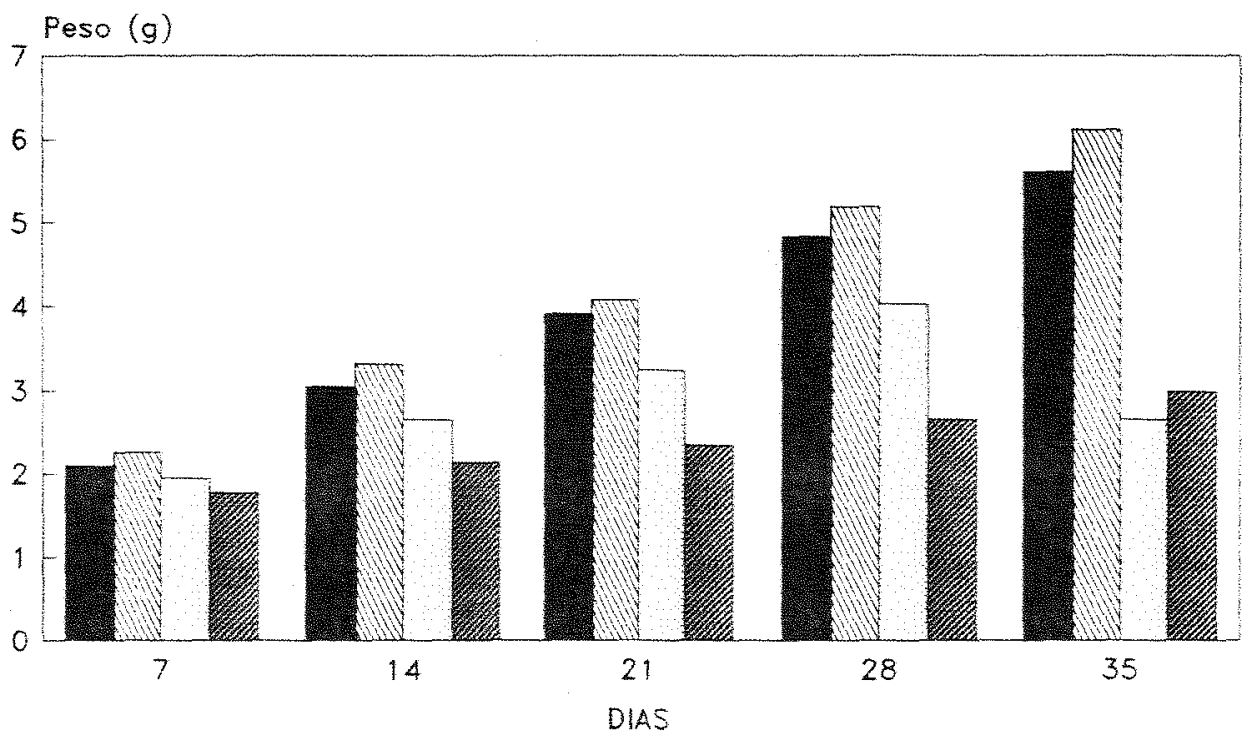

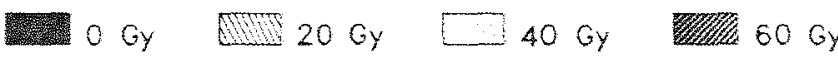


APENDICE 17 - NUMERO MEDIO DE ESPOROS

PRODUZIDOS PELO FUSARIUM EM BDA

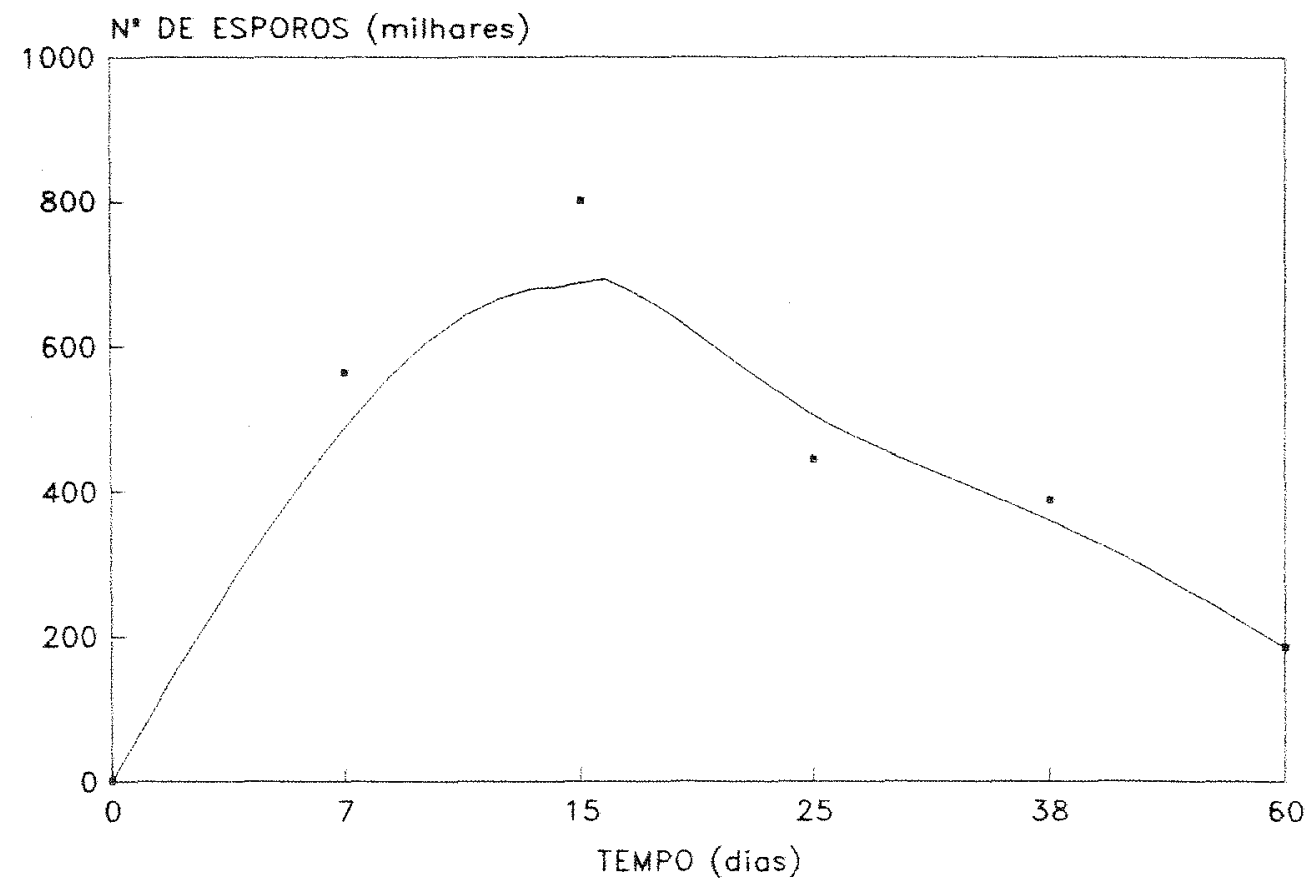

APENDICE 18 - VARIACOES FENOTIPICAS E FREQUENCIA POR DOSE DE RADIACAO
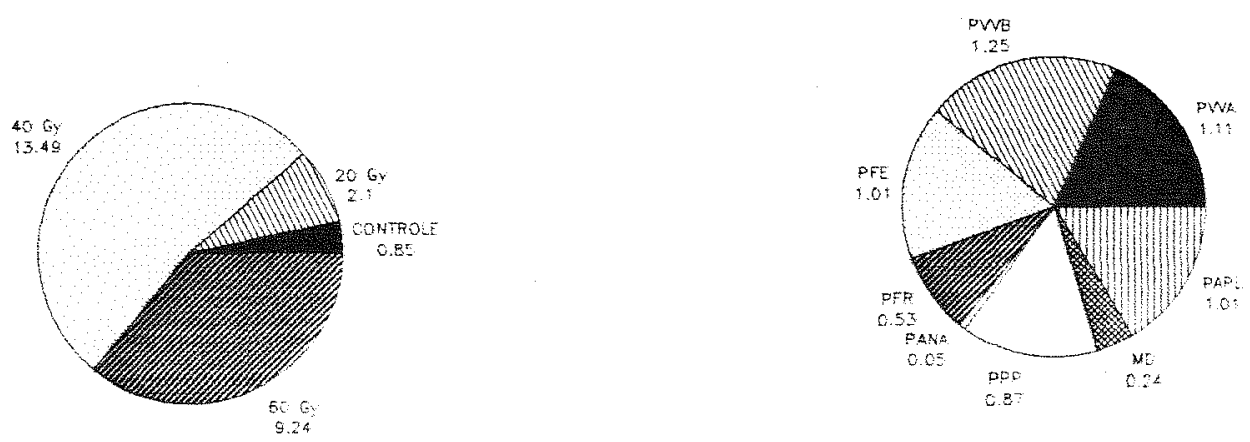